ホスホン酸・ホスフィン酸を活用する生物活性化合物の創製

横松 古

\title{
Development of Biologically Active Compounds on the Basis of Phosphonic and Phosphinic Acid Functionalities
}

\author{
Tsutomu Yokomatsu ${ }^{\dagger}$ \\ School of Pharmacy, Tokyo University of Pharmacy and Life Sciences; \\ 1432-1 Horinouchi, Hachioji, Tokyo 192-0392, Japan
}

(Received May 2, 2017)

\begin{abstract}
Phosphonic and phosphinic acids, especially $\alpha$-heteroatom-substituted ones, possess unique structural and physical features which enable them to act as hydrotically stable analogs to biological phosphates in biological processes. They also act as mimetics in the transition state of the protease-induced hydrolysis of dipeptides. The first half of this review focuses on selected new synthetic methods developed by our research group for the stereoselective synthesis of $\alpha$ heteroatom-substituted phosphonic and phosphinic acid derivatives, including modified nucleotide analogs and phosphinyl dipeptide isosteres. In the latter half, this review summarizes the utility of difluoromethylenephosphonic acids and phosphonic acid esters in the development of enzyme inhibitors against protein tyrosine phosphatases, sphingomyelinases, purine nucleoside phosphorylases and thrombin. The enzyme inhibitors developed were used as probes to elucidate signal transductions and the mechanisms of enzyme actions. The findings of the studies are briefly described.
\end{abstract}

Key words_ - phosphonate; phosphinate; phosphate mimic; dipeptide isostere; nucleotide analogue; enzyme inhibitor

\section{1.はじめに}

筆者は, 1979 年 3 月に東京薬科大学大学院薬学 研究科博士後期課程を修了後, カリフォルニア大学 アーバイン校で博士研究員として, 研究を開始し た.1）帰国後，幸いにも母校の薬品製造工学教室 (加納慎蔵教授・本学名誉教授）の助手として採用 された．助手及び講師を務めた 1980 年代は，精密 合成化学という言葉がはやり始めた時代だった。筆 者は, 留学時代の経験を活かして, アルカロイドの 精密合成法について研究した。この合成法では，ア シルイミニウム中間体の $\pi$ 電子環化反応を利用し ており，不斉中心を多数持つアルカロイドの新しい 立体制御合成法を確立することができた. ${ }^{2-4)}$

助教授昇進を機会に研究テーマを見直すこととし た. 当時, 時代の要請もあつて, 本学の化学系研究

東京薬科大学薬学部（干192-0392 東京都八王子市堀之 内 1432-1)

現住所：”東京薬科大学中央分析センター（† 192-0392

東京都八王子市堀之内 1432-1)

e-mail: yokomatu@toyaku.ac.jp

本総説は, 平成 27 年度退職にあたり在職中の業績を中 心に記述されたものである。
室の多くは，天然物の全合成を指向する精密合成化 学を展開していた。薬学的に有用な分子の設計・合 成，さらにその機能解析に力を注ぐメディシナルケ ミストリーと呼ばれる領域の研究は，かならずしも 十分に行われていなかった．新しいテーマを模索す るうちに, 生体内で不安定な化学結合をホスホン酸 やホスフィン酸などで化学修飾すると, メディシナ ルケミストリーとしても有用な化合物の創製につな がることが期待でき, 諸外国では, この領域の研究 が活発に行われていることを学んだ。しかし，わが 国の薬学領域ではあまり研究されていなかつた。 そ こで, 生体内で不安定な化学結合として, ペプチド 結合とリン酸エステル結合に主に注目し，生物活性 ペプチド及びリン酸エステルを「ホスホン酸・ホス フィン酸」と呼ばれる化合物群で化学修飾する研究 を展開した (Fig. 1).5)

本稿では，はじめに $\alpha$ 位にへテロ原子団を有す るホスホン酸及びホスフィン酸誘導体などの不斉合 成を目指した反応開発の経緯を簡単に概説する。後 半では，それらの素反応を利用して，ホスホン酸を 基盤とする新しい生物活性化合物を見い出した経緯 


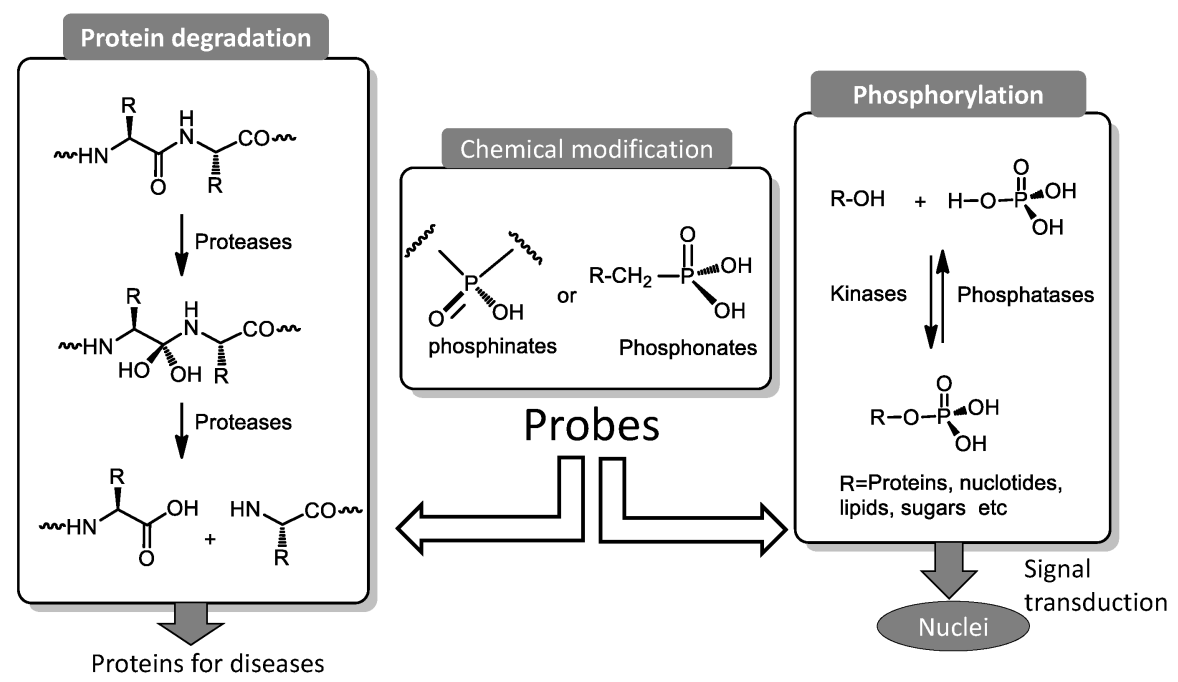

Fig. 1. Phosphonates and Phosphinates in Medicinal Chemistry

について述べる。

2. $\alpha$ 位にヒドロキシ基あるいはアミノ基を有す るホスホン酸誘導体の合成

$\alpha$ 位にヒドロキシ基を有するホスホン酸誘導体 ( $\alpha$-ヒドロキシホスホン酸誘導体) は, リン酸モ) エステルの安定な生物学的等価体として機能するこ とが期待できることから，リン酸エステル誘導体の 化学修飾の領域で注目を集めていた（Fig. 2)。6-10) また， $\alpha$-ヒドロキシホスホン酸誘導体は，ヒドロキ シ基をアミノ基に変換すれば， $\alpha$-アミノ酸のホスホ ン酸アナログ（ $\alpha$-アミノホスホン酸）に変換でき, 合成中間体としても有用と考えられた， $\alpha$-アミノホ スホン酸は，ある種のペプチドに組み込むと，遷移 状態理論に基づくペプチド性プロテアーゼ阻害剤の ジペプチドイソスターに利用でき，ペプチドミメ ティックスの分野で注目されていた（Fig. 2). ${ }^{11)}$

$\alpha$-ヒドロキシホスホン酸誘導体は，1）トリアル キルホスファイトをアルデヒドに熱的な求核付加す る方法（Abramov 反応），12-14) あるいは，2）亜リ ン酸ジアルキルのアニオンをアルデヒドに求核付加 反応させる方法（Pudovik 反応）で合成されてい

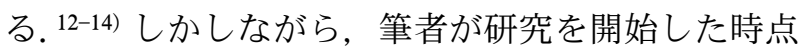
では，これらの方法を不斉反応に展開している報告 は，数例に留まっていた，そこで，これらの反応の 不斉反応への展開を試みた. ${ }^{15)}$

2-1. 不斉 Abramov 反応の開発 Abramov 反 応を不斉反応に展開するために，筆者は，プロキラ ルアルデヒドをホモキラルジオキサンアセタール 1

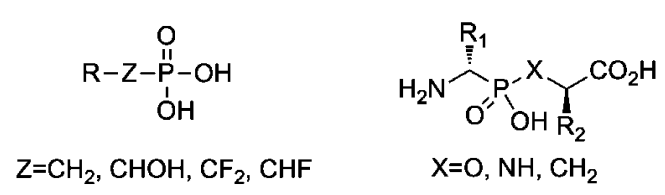

Fig. 2. Phosphoryl Mimetics for Phosphates and Dipeptides

に変換後, ルイス酸存在下でトリエチルホスファイ トと低温で反応させる方法を検討した（Scheme

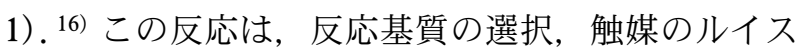
酸性を適切に調整すると，アセタールがトリエチル ホスファイトにより $S_{N} 2$ 型の求核攻撃を受け， 2 が 高いジアステレオ選択性（>95\% de）で生成した. 2 は，キラル補助基を除去すると，目的とした $\alpha$-七 ドロキシホスホン酸エステル 3 が高い光学純度で得 られた．化合物 $\mathbf{3}$ は，ヒドロキシ基をアミノ基に変 換すると， $\alpha$-アミノホスホン酸 5 に容易に変換でき た.

前述したように， $\alpha$-ヒドロキシホスホン酸誘導体 は，リン酸エステルの安定な生物学的等価体として

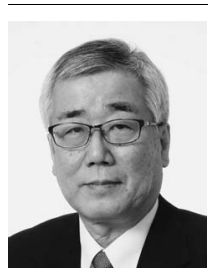

横松 力
1979 年東京薬科大学大学院薬学研究科 博士後期課程修了。1979 年カリフォル ニア大学アーバイン校博士研究員. 東 京薬科大学薬学部助手, 講師, 助教授 を経て，2004 年東京薬科大学薬学部教 授。乙の間, 医療衛生薬学科学科長, 学長補佐などを歴任。2016 年 3 月定年 退職. 2016 年東京薬科大学名誉教授. 2016 年より東京薬科大学中央分析セン 夕一特命教授. 


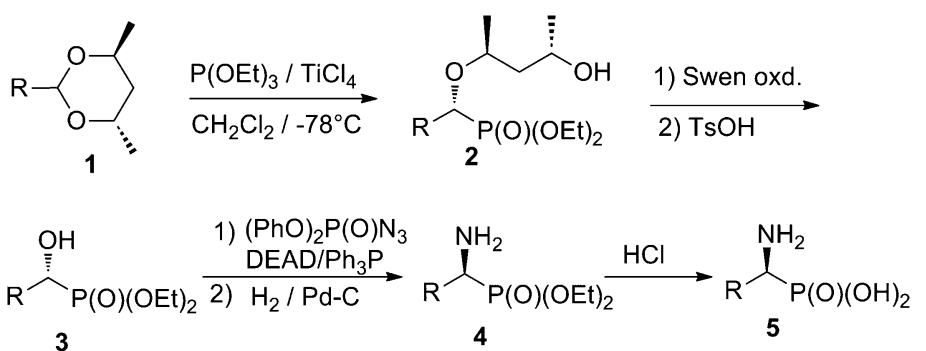

Scheme 1. Stereoselective Synthesis of $\alpha$-Hydroxyphosphonates from Homochiral Dioxane Acetals
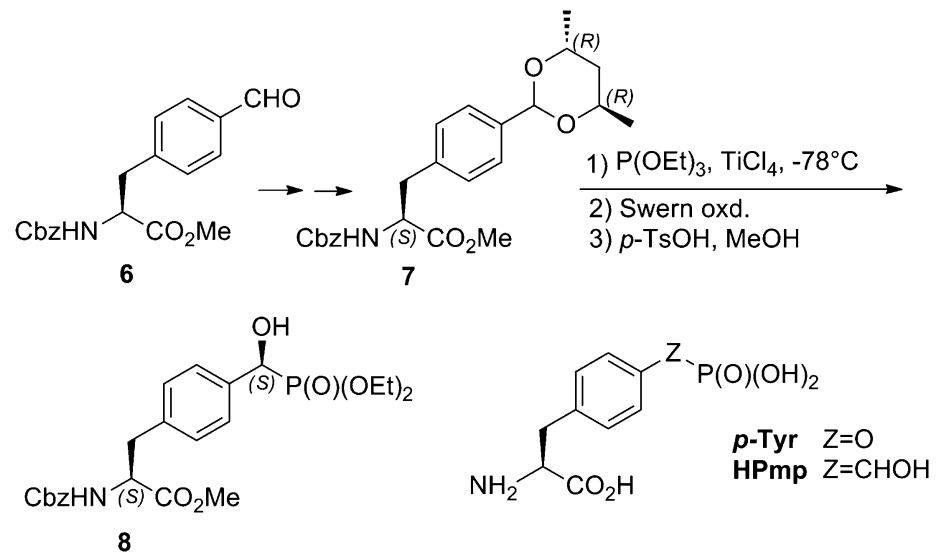

Scheme 2. Stereocontrolled Synthesis of Hydroxymethylene Phosphonate Analogues of Phosphorylated Tyrosine

も注目されており, リン酸エステルの化学修飾に利 用されていた。なかでも, リン酸化チロシン（pTyr）は，タンパク質ータンパク質間の相互作用に 重要な役割を演じていることが明らかになり, pTyr のエステル酸素をヒドロキシメチン $(\mathrm{CHOH})$ に置き換えた $\alpha$-ヒドロキシホスホン酸誘導体 （HPmp）の合成も注目されていた（Scheme 2). 17) しかしながら，既存の合成法では， $\alpha$ 位のヒドロキ シ基の立体配置を立体選択的に構築することができ なかった。

筆者は，L-ホルミルフェニルアラニン誘導体 6 か ら容易に誘導されるキラルアセタール 7 を $\mathrm{TiCl}_{4}$ 存 在下，低温でトリエチルホスファイトと作用させ， 引き続き不斉補助基を除去すると， HPmp の合成 中間体 8 を立体選択的に合成することを見い出した (Scheme 2).18) 本法は, キラル補助基として， $(S, S)$ アセタールを用いると，8 のジアステレオマーが立 体選択的に合成できる.

\section{2-2. 不斉Pudovik 反応の開発亜リン酸ジア} ルキルは，ホスホネート $\mathbf{a}$ とスファイト $\mathbf{b}$ の互 変異性の平衡混合物として存在するが, 塩基を作用

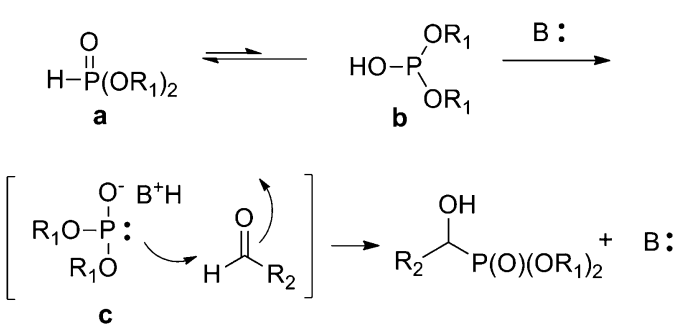

Scheme 3. Pudovik Reaction Catalyzed by a Base

させると平衡はホスファイトに傾きアニオン $\mathbf{c}$ が生 成する (Scheme 3).アニオン $\mathbf{c}$ とアルデヒドの反 応から $\alpha$-ヒドロキシホスホン酸誘導体を得る反応 は Pudovik 反応と呼ばれている. ${ }^{14)}$ Pudovik 反応を 不斉反応に展開するためには，1）ホスホナートの エステル部分をキラルにする，あるいは，2）キラ ルな塩基 B を用いるなどが考えられる。筆者が研 究を開始した当時，1）の方法については，既に,

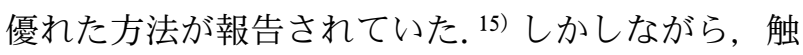
媒量のキラルな塩基 B を用いる Pudovik 反応は, キニーネを用いる方法が一例報告されているのみで あつた. ${ }^{19,20)}$

筆者は, 不斉 Pudovik 反応への展開を期待し 


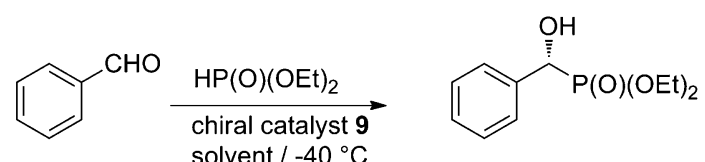

$\mathrm{Et}_{2} \mathrm{O}: 53 \%$ ee, Toluene: $36 \%$ ee $\mathrm{CH}_{2} \mathrm{Cl}_{2}: 0 \%$ ee



$\mathrm{X}=\mathrm{MeO}: 82 \%$ ee, $\mathrm{X}=\mathrm{Me}: 58 \%$ ee $\mathrm{X}=\mathrm{H}: 20 \%$ ee, $\mathrm{X}=\mathrm{Cl}: 17 \%$ ee
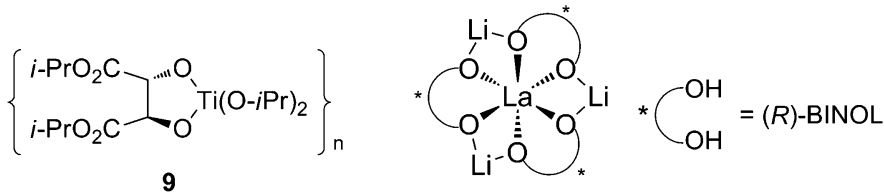

(R)-LLB

Scheme 4. Chiral Transition Metal-catalyzed Pudovik Reaction with Aldehydes

て，従来のアルキルアミン，アルカリ及びアルカリ 土類金属塩に代わる Pudovik 反応の活性化剂とし て，遷移金属錯体を適用したところ， $\mathrm{Ti}\left(\mathrm{OPr}^{\mathrm{i}}\right)_{4} や$ $\mathrm{La}\left(\mathrm{OPr}^{\mathrm{i}}\right)_{3}$ が有効に機能することを見い出した. ${ }^{21)}$ そこで，不斉 Pudovik 反応に展開するために， Sharpless の不斉チタン触媒 922-24) 及び Shibasaki ら が開発途上であった $(R)$-ランタンリチウムバイ ノール $[(\boldsymbol{R})-\mathbf{L L B}]^{25,26)}$ に注目し，これらの触媒存 在下に亜リン酸ジエチルとアルデヒドとの反応を検 討した (Scheme 4).

不斉チタン触媒 9 を用いた場合，顕著な溶媒効果 が認められ，エーテルなどドナー性溶媒が効果的で あり，9がルイス塩基として作用するものと考えら れる. ${ }^{27,28)}(\boldsymbol{R})$ - -LLB を触媒として用いると, 脂肪族 アルデヒドとの反応は，全く選択性を示さなかっ た。しかし，芳香族アルデヒドとの反応は，芳香核 上の置換基効果を受けるが，アニスアルデヒドとの 反応では，高いエナンチオ選択性（82\% ee）で， 対応する Pudovik 生成物が得られた. ${ }^{28,29)}$ 本法は, 不斉遷移金属錯体を用いる不斉 Pudovik 反応の最 初の報告例となつた. ${ }^{30)}$

その後, Shibasaki らにより, エナンチオ選択性 の高い触媒系が見い出された（Scheme 5).31) Shibasaki らは，不斉金属錯体として， $\mathrm{LiAlH}_{4}$ と $(R)$-binapthol から調製される触媒 $[(\boldsymbol{R})$-ALB $]$ を 用いると，脂肪族アルデヒドでも高いエナンチオ選 択性を示す Pudivik 反応が進行することを見い出し
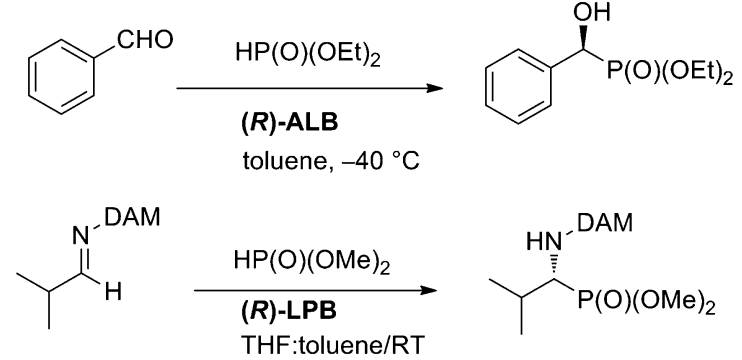

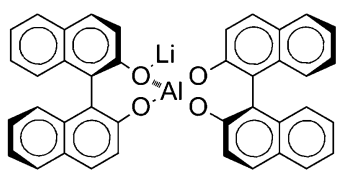

$(R)$-ALB

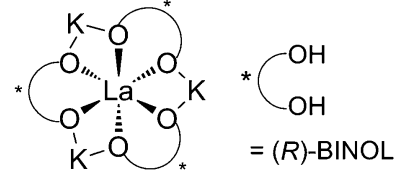

(R)-LPB
Scheme 5. Improved Catalysts for Asymmetric Pudovik Reactions

ている. ${ }^{31)}$ また， $(\boldsymbol{R})$-LLB のリチウムをポタシウ ムに置換した触媒 $[(\boldsymbol{R})$-LPB $]$ を用いると，アル ドイミン類に対しても高いエナンチオ選択性で Pudovik 型の付加反応が進行することが報告され た. ${ }^{32)} さ ら に ，$ 最近では，不斉有機分子触媒を利用 する Pudovik 反応も報告されるようになり, ${ }^{33)}$ Pudovik 型の反応は不斉触媒の機能評価を検討する 際の反応としても位置づけられるようになっている.

\section{3. $\beta$-アミノ $-\alpha$-ヒドロキシホスホン酸誘導体の合} 成

$\beta$-アミノ $\alpha$-ヒドロキシホスホン酸あるいは $\beta$-ア ミノ- $\alpha$-ヒドロキシホスフィン酸を組み込んだオリ 


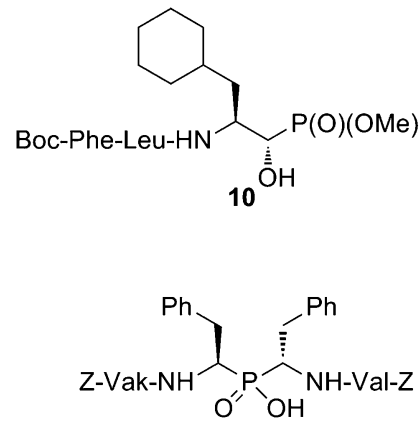

12

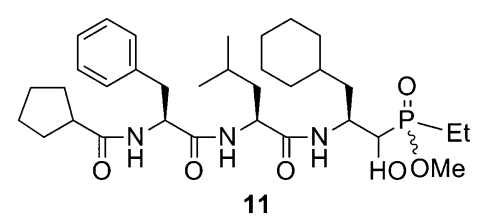

$\mathrm{Nal-Val-HN}]_{\mathrm{OH}}^{\left.\stackrel{\mathrm{O}}{\mathrm{O}}\right|_{\mathrm{OH}} ^{\mathrm{Ph}}} \mathrm{NH-Val-Nal}$

Fig. 3. Biologically Active Peptides Possessing Phosphonate and Phosphinate Moieties

ゴペプチド 10 及び 11 は，レニン阻害活性を発現す ることが知られていた (Fig. 3). ${ }^{34-36)}$ また，Peyman らは, HIV プロテアーゼが $\mathrm{C}_{2}$ 軸対称性ホモダ イマーとしてプロテアーゼの機能を示すことに注目 して， $C_{2}$ 対称性あるいは擬対称性のオリゴペプチ ド 12 及び 13 を合成し，それらに強い HIV 阻害活 性を見い出していた（Fig. 3). ${ }^{37,38)}$

以上のオリゴペプチドを構成する $\beta$-アミノ $-\alpha$-ヒ ドロキシホスホン酸あるいは $\beta$-アミノ- $\alpha$-ヒドロキ シホスフィン酸は, 高いジアステレオ選択性で得る ことが困難であったため， ジアステレオマーの混合 物がオリゴペプチドに組みこまれて活性評価が行わ れていた。

3-1. ジアステレオ選択的 Abramov 反応の利用

筆者は, 以上の問題を解決するために, ルイス酸 触媒下の $\alpha$-ジベンジルアミノアルデヒド 14 のキ レート及び非キレート制御下の Abramov 型の反応 を検討した (Scheme 6). ${ }^{39)}$ すなわち， $\mathrm{TiCl}_{4}$, $\mathrm{Et}_{2} \mathrm{AlCl}, \mathrm{BF}_{3} \cdot \mathrm{Et}_{2} \mathrm{O}$ などのルイス酸の存在下, 14 にシリルホスファイトを作用させると, 反応は非キ レート遷移状態を経て進行しエリスロ体 $\mathbf{1 5}$ が高選 択的に生成した. 一方, 過剰の $\mathrm{TiCl}_{4}$ 存在下でジエ チルホスファイトを作用させると, 反応はキレート 遷移状態を経て進行し，トレオ体 $\mathbf{1 6}$ が高選択的に 得られた。すなわち, 求核剤と反応条件を変化させ ることにより，立体分岐的な反応が高選択的に進行 することが明らかとなった。

同様に， $\alpha$-ベンジルオキシアルデヒド 17 をシリ ルホスファイトと $\mathrm{TiCl}_{4}$ 存在下に処理すると, キ レート制御下の反応が進行し，18 が高収率かつ高 選択的に得られた. ${ }^{40)} 18$ は，ヒドロキシ基をアミノ 基に変換するとオキシアミノ酸のホスホン酸アナロ

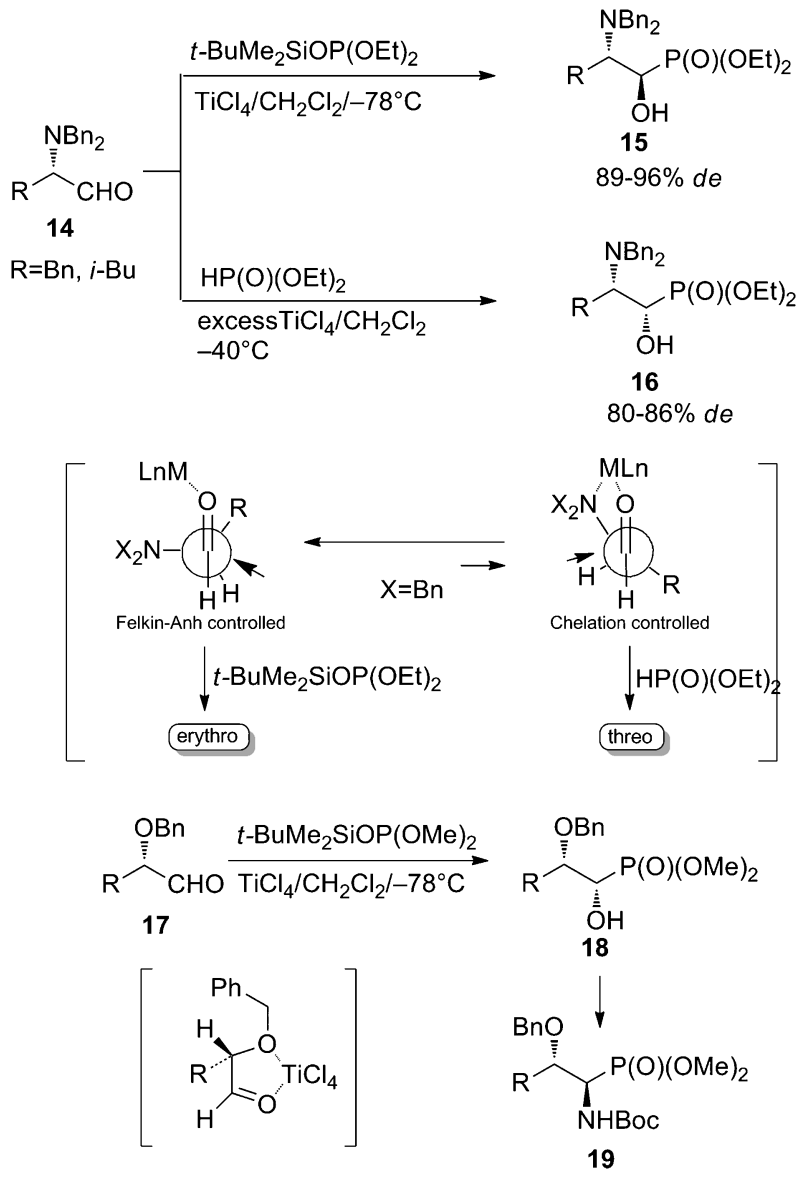

Scheme 6. Hydrophosphonylation of $\alpha$-Dibenzylamino Aldehydes and $\alpha$-Benzyloxy Aldehydes

グ 19 に変換できる（Scheme 6).

3-2. $\beta$-アミノ- $\alpha$-ヒドロキシホスフィン酸合成へ の展開 以上の知見を踏まえて, 次に, 求核剤に アリルホスフィン酸エチル 20 及びエチルホスフィ ン酸エチル 21 を用いて， $\alpha$-ジベンジルアミノアル デヒド 14 のホスフィニル化反応を検討した (Scheme 7). 41-46) この反応においては，ルイス酸は 


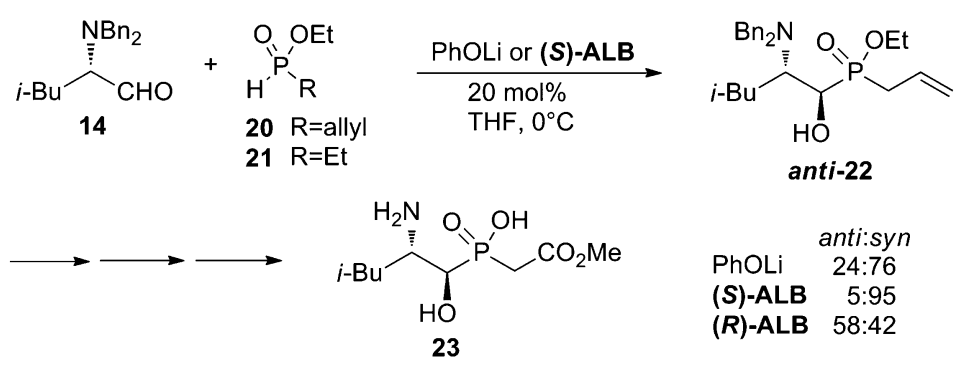

Scheme 7. Hydrophosphinylation of $\alpha$-Dibenzylamino Aldehydes with Alkyl- $H$-phosphinates

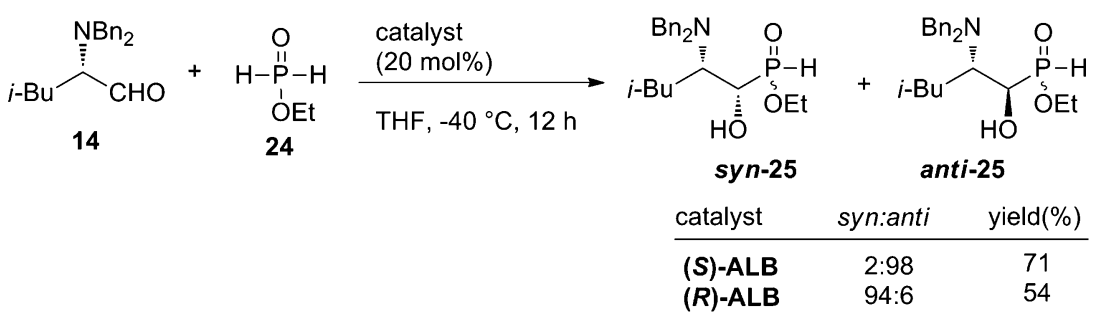

Scheme 8. Hydrophosphinylation of $\alpha$-Dibenzylamino Aldehydes with Ethyl Phosphinate

触媒として有効に機能しなかったが，14 と 20 を触 媒量のリチウムフェノキシド（PhOLi） と低温で作 用させると，付加物 $\mathbf{2 2}$ が中程度の選択性 (52\% de) で得られた。この反応において，PhOLi と類似の 機能を有する不斉金属触媒 $(S)$-ALB を用いると anti-22 が 90\% de で得られた。しかし， $(\boldsymbol{R})$-ALB を用いるとジアステレオ選択性の低下が観測され た. ${ }^{41)}(S)$-ALB を用いた反応において，ジアステレ 才選択性が高まったのは， $(S)$-ALB と基質の不斉 がマッチして重複不斉誘導が生じたためと考えられ る. エチルホスフィン酸エチル 21 を求核剤として 用いても，同様の結果が得られた。anti-22 は，数 工程でオリゴペプチドに誘導可能なジペプチドイソ スター 23 に変換された (Scheme 7). 41)

ホスフィン酸エチル 24 とアミノアルデヒド 14 の 反応では， $(S)$-ALB を触媒として用いると, anti25 が高いジアステレオ選択性で得られた. ${ }^{42,43)}$ 一 方，(R)-ALB を用いると，syn-25 が高選択的に得 られた，本反応のジアステレオ選択性は，不斉金属 触媒の不斉により制御されていることが明らかと なった（Scheme 8).

$\alpha$-アミノホスフィン酸を組み込んだ対称性あるい は擬対称性のオリゴペプチド $\mathbf{1 2}$ 及び 13 に着目し， それらの類縁体の合成を目的として，キラルな $\alpha$-アミノ- $H$-ホスフィナート 26 とプロキラルなアル デヒドあるいはイミンとの反応を検討した

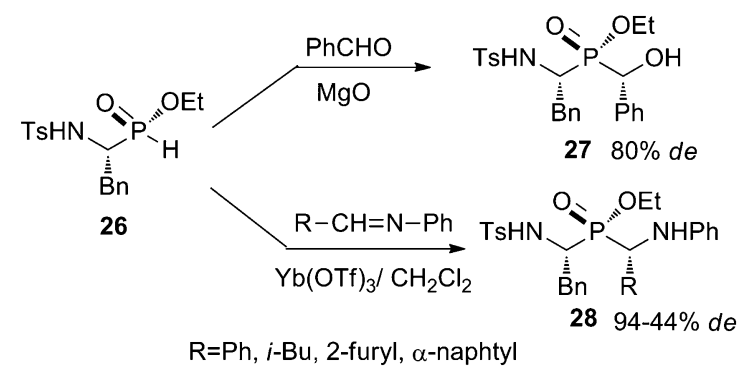

Scheme 9. Stereoselective Synthesis of $\alpha, \alpha^{\prime}$-Heteroatom-substituted Phosphinates

(Scheme 9). ${ }^{44,45)}$

ベンズアルデヒドとの反応では，塩基触媒として 酸化マグネシウムを用いると高ジアステレオ選択的 なホスフィニル化反応が進行し 27 が高収率で得ら れることが明らかとなった. ${ }^{44)}$ 一方，イミンとのホ スフィニル化反応では, 活性化剂として触媒量の $\mathrm{Yb}(\mathrm{OTf})_{3}$ が有効であった。この反応のジアステレ 才選択性は，イミンの置換基（R）の嵩高さにより 変化したが，嵩高いナフチル基を有するイミンとの 反応では，28 が極めて高い選択性（94\% de）で得 られた. ${ }^{45}$

3-3. 不斉ジヒドロキ化反応（AD 反応）の利用 vic-ジオール誘導体の簡便にかつ立体選択的に合 成する一般的な方法の 1 つに，オレフィン類のオス ミニウム酸化反応を利用する方法が挙げられる. 1990 年頃から，オスミニウム酸化を利用するオレ 


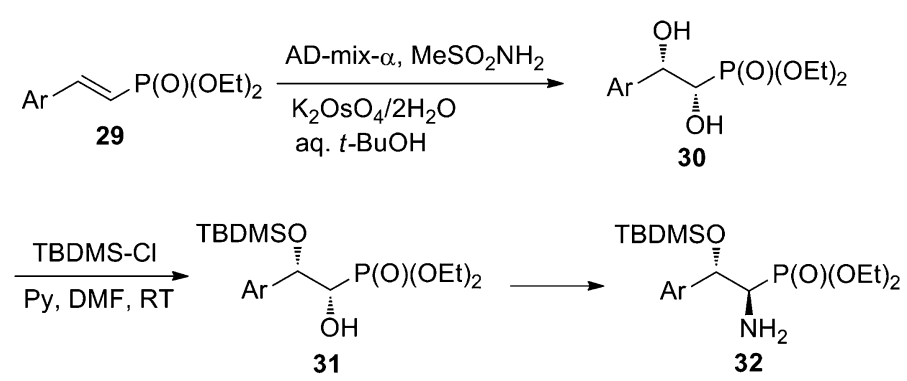

Scheme 10. Asymmetric Dihydroxylation of Alkenylphosphonates

フィン類のジヒドロキシ化反応は，不斉反応への展 開が検討され，優れた反応系が開発されていた。 な かでもシンコナアルカロイド誘導体を不斉配位子に 用い, $\mathrm{K}_{2} \mathrm{Fe}(\mathrm{CN})_{6}$ をオスミニウムの再酸化剂とし て用いる Sharpless らの不斉ジヒドロキシ化反応 （AD 反応）は，不斉配位子の入手が容易で基質の 適用範囲も広いこと，また，反応に必要なすべての 反応剂を含有する $\mathrm{AD}-\mathrm{mix}$ 試薬が利用可能なこと から，実用的な反応系の 1 つであつた. ${ }^{47)}$ しかしな がら，ホスホン酸誘導体の不斉合成に利用した研究 は報告されていなかった。

そこで，筆者は，エナンチ才選択性に与えるホス ホナート基の効果などの検証，並びに， $\alpha$-アミノホ スホン酸誘導体の不斉合成への展開を念頭におい て, 不飽和ホスホナート類の AD-mix 試薬を用い た不斉ジヒドロキシ化反応を検討した（Scheme 10). 48-51) その結果，エナンチオ選択性は，基質の $\beta$ 位に芳香族基が置換されていると，高まることが 明らかとなった。 また，ホスホン酸エステルの嵩高 さは，エナンチオ選択性に影響を及ぼすことを明ら かとした，さらに，AD 反応により得られたジオ一 ル 30 は, 嵩高いシリルクロライドで処理すると, $\beta$ 位のヒドロキシ基が選択的に保護され，31 が得 られた. 31 はオキシアミノ酸のホスホン酸アナロ グ 32 に変換された. ${ }^{51)}$

4. $\omega$ 位にホスホニル基を有する $\alpha$-アミノ酸誘 導体の合成

L-AP-3 及び L-AP-4 などの側鎖末端（ $\omega$ 位）に ホスホニル基を有する $\alpha$-アミノ酸誘導体は，グル タミン酸受容体のサブタイプ受容体（NMDA 受容 体）に対するアンタゴニスト活性を示すことが知ら れていた（Fig. 4).52)これらの知見は，アゴニスト である L-グルタミン酸の末端カルボキシ基を嵩高 いホスホン酸型バイオイソスターで置き換える化学

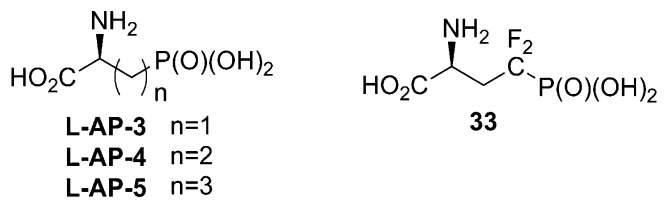

Fig. 4. $\omega$-Phosphono- $\alpha$-amino Acids

修飾によるもので，ホスホニル基と $\alpha$-アミノ酸部 分の空間的な距離は，アンタゴニスト活性に相関す ると推定されていた。 ${ }^{53)}$ また，33 は，リン酸化セリ ン（p-Ser）の非水解性プローブとして, $p$-Ser 含有 シグナルタンパク質の機能解析に利用されてい た. ${ }^{54,55)}$

一方，1990 年頃から，リパーゼが触媒するエス テル類の不斉加水分解反応あるいは有機溶媒中での アルコール類の不斉アシル化反応は，一般に高い不 斉認識能を示すことから，ラセミアルコール類の光 学分割法として広く利用されるようになってい

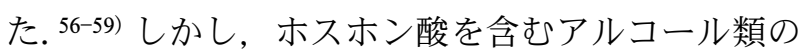
光学分割剂としてのリパーゼの有用性は十分に明ら かとなっていなかった。

そこで，筆者は，L-AP-3， L-AP-4 及びフッ素ア ナログ 30 の不斉合成を目的として，対称 1,3-プロ パンジオール 34a-c の有機溶媒中でのリパーゼ触媒 下のビニルアセテートとのエステル交換反応を検討 した (Scheme 11). ${ }^{60)}$ 種々の条件を検討したとこ ろ, エーテル系溶媒中で, lipase PS を触媒とする と, 高いエナンチオ選択性（96-98\% ee）でエステ ル交換反応が進行し, 光学活性アセテート $\mathbf{3 5 a}-\mathbf{c}$ が 生成することが明らかとなった。ここに得られた 36a-c の絶対配位は，Kazlasukas らが提唱していた lipase (Pseudomonas ceparia) の基質認識モデル61) から予想される絶対配位とよく一致していた。 また, フッ素を含む基質 $34 \mathbf{c}$ は，フッ素を含まない基質 34b と比べて, エステル交換反応が 4 倍程度速く進 


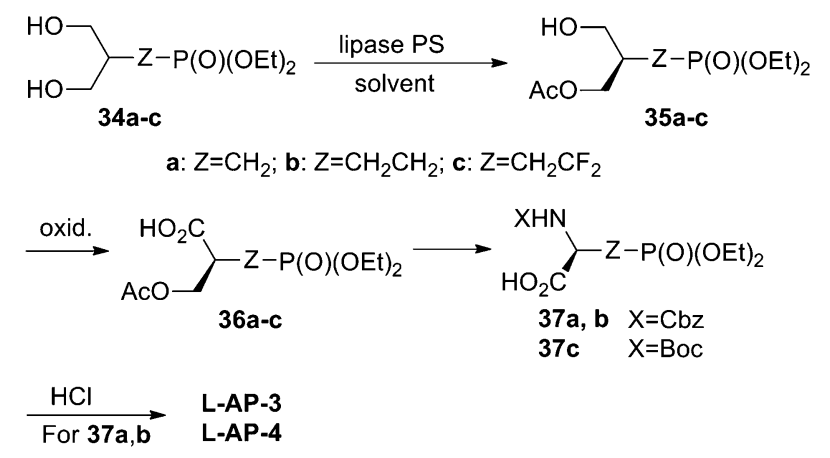

Scheme 11. Asymmetric Synthesis of $\omega$-Phosphono- $\alpha$-amino Acids

行した.フッ素原子はリパーゼの基質認識部位との 親和性に大きな影響を及ぼすことが明らかとなった。 35a-c は, 数工程の官能基変換反応を経て， 37a, 37b 及び 37c に誘導した。 $37 \mathbf{a}$ 及び 37b は，脱保護 して L-AP-3，L-AP-4 に変換した。37cは，p-Ser の安定類縁体として, ペプチドに誘導可能であ る. ${ }^{54,55)}$

前述したように， $\omega$-ホスホノ- $\alpha$-アミノ酸のホス ホニル基と $\alpha$-アミノ酸部分の空間的な距離 $[\mathrm{C}(2)$ -P 空間距離］は，アンタゴニスト活性に相関があ ると推定されており，そのプローブとして配座固定 型類縁体の合成が求められていた。 ${ }^{53)}$ 筆者は，これ まで知られていた L-AP-5 の配座固定類縁体のアン タゴニスト活性と C (2) -P 空間距離の関係を解析し たところ，その空間距離が $4.56 \AA$ のときに，最も 高い受容体結合能を示すと推定した．そこで，この 空間距離に近似させた L-AP-5 の配座固定類縁体 44 及び 45 を設計し，合成を検討した（Scheme 12). ${ }^{62)}$

本合成法では，環状硫酸エステル $\mathbf{3 8}$ の環開裂を 利用して合成されるホスホノアルコール 39 の光学 分割をはじめに検討した。 その結果，lipase AK 触 媒下でビニルアセテートとのエステル交換反応を行 うと, 高いエナンチオ比 $(E=152)$ で酵素反応が 進行し, 光学純度の高いアセテート 40 とアルコー ル 41 が得られた。 アルコール 41 は，ヒダントイン 42 及び 43 を経由して, 目的とした AP-5 の配座固 定型類縁体 44 及び 45 に誘導された。

\section{5. リン酸部修飾ヌクレオチドアナログの合成}

5-1. アンチセンスオリゴヌクレオチドを指向す る合成研究 RNA に相補的な塩基配列を有する 天然型オリゴヌクレオチドは，対象遺伝子と安定な

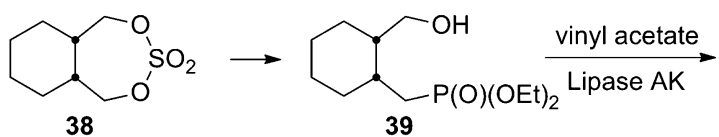<smiles>CCOCC[C@H]1CCCC[C@H]1COC(C)=O</smiles><smiles>CCOCC1CCCC[C@@H]1CO</smiles><smiles>CCOC[C@H]1CCCC[C@@H]1C1NC(=O)NC1=O</smiles><smiles>CCOCPC[C@H]1CCCC[C@@H]1C1NC(=O)NC1=O</smiles><smiles>CC(=O)CC1CCCCC1C(N)C(=O)O</smiles><smiles>[13CH3]C[C@H]1CCCC[C@H]1C(N)C(=O)O</smiles>

Scheme 12. Synthesis of Conformational Constrained Analogues for AP-5

二重鎖を形成し，アンチセンスオリゴヌクレオチド

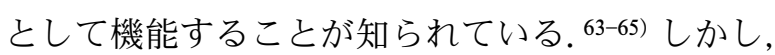
天然オリゴヌクレオチドは, リン酸ジエステル結合 が体液や細胞培養液に含まれるヌクレアーゼにより 容易に加水分解を受け，その機能を消失する欠点が ある. ヌクレアーゼに安定なオリゴヌクレオチドの 構成ユニットとして，ホスホジエステル結合の酸素 原子の 1 つをメチレンに置換したリン酸部修飾ジヌ クレオチドアナログ 51 の合成を検討した（Scheme 13). ${ }^{66-68)}$

D-グリセルアルデヒドから容易に誘導可能な共役 ホスホナート 46a を低温でラジカル環化すると，標 的ヌクレオチドのグリコシド相当部 $\mathbf{4 7 a}$ が高い選択 性で得られた。 ${ }^{66)}$ 47a とシリルチミン $\left[(\mathrm{TMS})_{2} \mathrm{~T}\right]$ との $N$-グリコシル化反応は, 種々の条件を検討し たが，高い選択性が得られなかった。一方，共役木 スホノチオエート 46b から誘導したグリコシド 47b を糖供与体として用いると， $(\mathrm{TMS})_{2} \mathrm{~T}$ の $N$-グリコ シル化反応は, $\mathrm{TiCl}_{4}$ 存在下, 低温で進行し, 高い 選択性でヌクレオチドアナログ $49(\alpha: \beta=96: 4)$ が生成した。 ${ }^{67)}$ 選択性が高まるのは，ホスホノチ才 エート基の隣接基効果により二環性力チオン中間体 48 が速やかに形成され，48 の $\beta$ 面から反応が優先 的に起こることによると考察した。 また，49 は小 


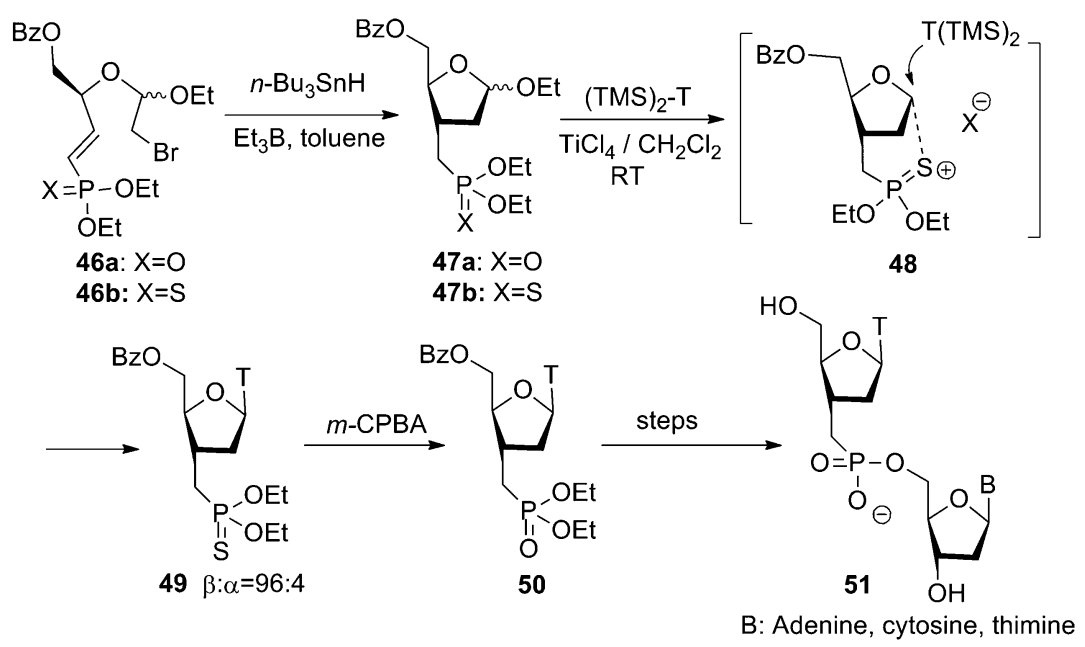

Scheme 13. Stereocontrolled Synthesis of Phosphonate Analogues of 2'-Deoxyribonuceloside 3'-Phosphates

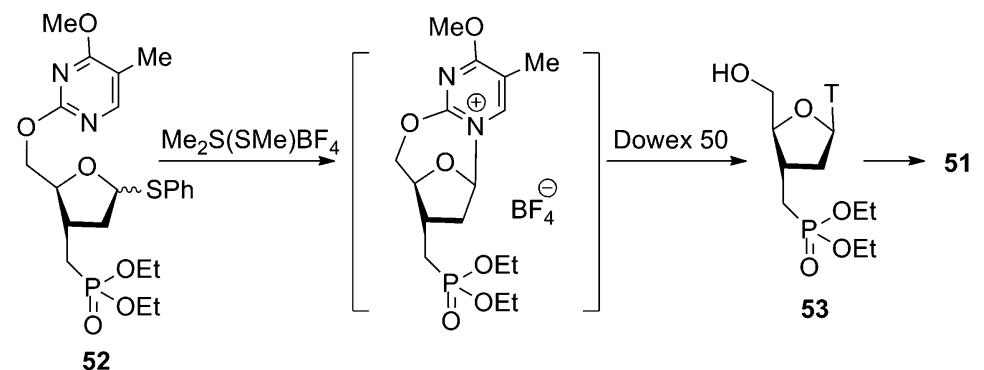

Scheme 14. Intramolecular N-Glycosylation for Nucleotide Analogues
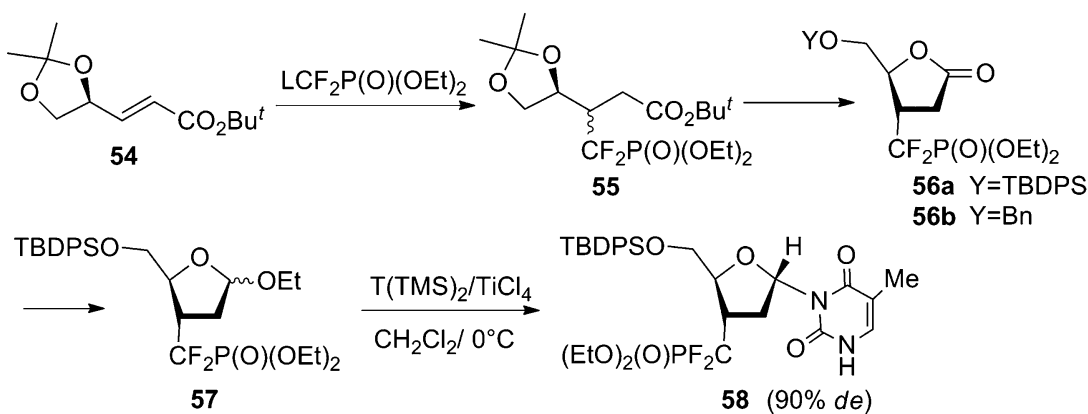

Scheme 15. N-Glycosylation with Glycosyl Donors Possessing a Group of " $\mathrm{CF}_{2} \mathrm{P}(\mathrm{O})(\mathrm{OEt})_{2}$ ”

スホン酸誘導体 $\mathbf{5 0}$ に容易に変換可能で, ジヌクレ オチドアナログ 51 の合成に利用できた.

なお，50 の脱ベンゾイル体 53 は，52 の分子内 $N$-グリコシル化反応を利用する方法でも合成が可 能であった (Scheme 14). ${ }^{68)}$

以上の知見を踏まえて, リン酸エステルとの等価 性をさらに高めた類縁体の合成を目指して，3 位に ジフルオロメチレンホスホニル基 $\left[\mathrm{CF}_{2} \mathrm{P}(\mathrm{O})\right.$ $(\mathrm{OEt})_{2}$ ] を有する糖供与体 $\mathbf{5 4}$ とシリルチミン
[ ( TMS $\left.)_{2} \mathrm{~T}\right]$ の $N$-グリコシル化反応を検討した (Scheme 15). ${ }^{69,70)}$ D-グリセルアルデヒドから得ら れた共役エステル 54 に, Michael 反応を利用して $\mathrm{CF}_{2} \mathrm{P}(\mathrm{O})(\mathrm{OEt})_{2}$ 基を導入すると, 55 がジアステレ オマーの混合物として得られた。 55 を酸で処理す ると, ジアステレオマーの 1 つだけがラクトン化さ れ，もう一方のジアステレオマーは分解した． 得ら れたラクトンは，ヒドロキシ基の保護及び官能基変 換反応を経由して 57 に変換された. 57 と (TMS) ${ }_{2} \mathrm{~T}$ 


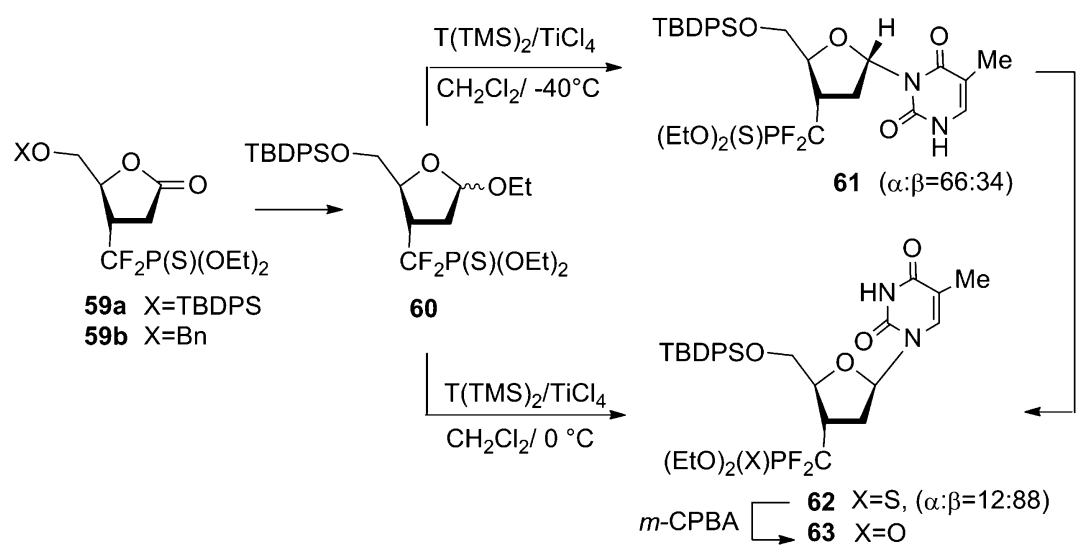

Scheme 16. N-Glycosylation with Glycosyl Donors Possessing a Group of " $\mathrm{CF}_{2} \mathrm{P}(\mathrm{S})(\mathrm{OEt})_{2}$ ",

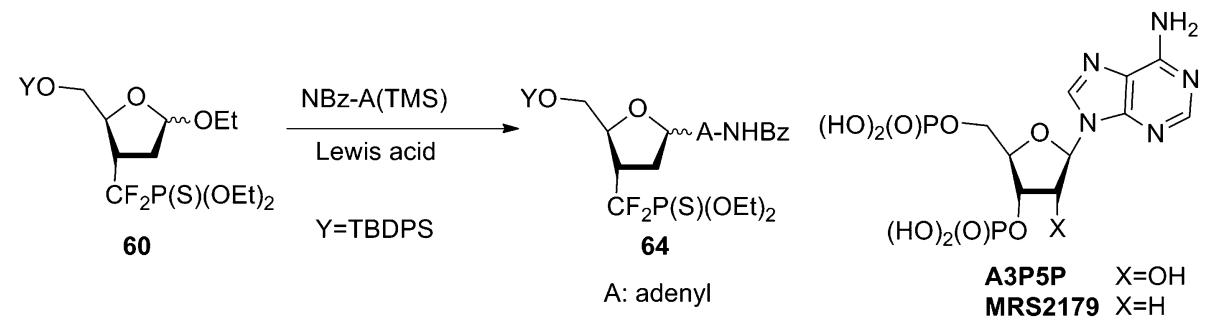

Scheme 17. $N$-Glycosylation of Adenine with Glycosyl Donor 60

を $\mathrm{TiCl}_{4}$ 存在下 $0^{\circ} \mathrm{C}$ で反応させたところ，N-グリコ シル化反応は糖供与体の $\alpha$ 面から進行し, さら に，予期に反してチミンの 3 位窒素がグリコシル化 された付加物 $\mathbf{5 8}$ が高選択的（90\% de）に得られ， 所望の付加物は得られなかつた。

そこで, 次に, ホスホノチオエート型の糖供与体 60 を用いて， $(\mathrm{TMS})_{2} \mathrm{~T}$ の $N$-グリコシル化反応を 検討した (Scheme 16). ${ }^{69,70)}$ このグリコシル化反応 において， $\mathrm{TiCl}_{4}$ 存在下，低温 $\left(-40^{\circ} \mathrm{C}\right)$ で反応を 行うと，ホスホナート型糖供与体 $\mathbf{5 7}$ を用いた場合 と同様に，チミンの 3 位がグリコシル化された付加 物 61 がジアステレオマーの混合物として得られ た。一方, 反応を $0^{\circ} \mathrm{C}$ に昇温して行うと, 所望のヌ クレオチドアナログ 62 が高い選択性 $(\alpha: \beta=12$ : 88）で得られた。 62 は，対応するホスホナート 63 に容易に変換できた。なお， 61 は， $0^{\circ} \mathrm{C} て ゙ ~ \mathrm{TiCl}_{4}$ と 処理すると，62 に高選択的に異性化した。このこ こから，このグリコシル化反応では，61 が速度論 的に生成した後, 熱力学的に安定な 62 に異性化し ていると考えられる。

5-2. $P 2 Y_{1}$ 受容体拮抗薬を指向するヌクレオチ ドアナログの合成研究＼cjkstart近年，ATP は，細胞内
においてシグナルタンパク質のリン酸化においてリ ン酸源を供給するばかりか, 細胞外の情報伝達物質 として受容体に作用し，多くの重要な生理機能を有 していることが明らかとなっている. $\mathrm{P} 2 \mathrm{Y}_{1}$ 受容体 は，ATP 受容体のサブタイプの 1 つで，血小板の 凝集などの生理活性の発現に関与している. ${ }^{71)}$

3'位及び $5^{\prime}$ 位のヒドロキシ基がリン酸化されたア デノシン誘導体（A3P5P） は，内因性の $\mathrm{P} 2 \mathrm{Y}_{1}$ 受容 体のアンタゴニストで, 弱いアンタゴニスト活性を

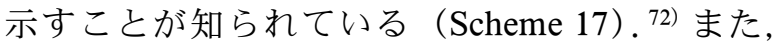

A3P5P の 2'-デオキシアナログ（MRS2179）にも 弱い活性が認められていた。. ${ }^{72)}$ 筆者は, MRS2179 の $3^{\prime}$ 位のリン酸エステルを加水分解に安定な類縁 体へ化学修飾する目的で，前述した $N$-グリコシル 化反応で，良好な結果が得られた糖供与体 $\mathbf{6 0}$ を用 いて，N-ベンゾイルシリルアデニン [ NBz$\left.\mathrm{A}(\mathrm{TMS})_{2}\right]$ との $N$-グリコシル化反応を検討した (Scheme 17). ${ }^{69,70)}$ しかしながら，この $N$-グリコシ ル化反応は，糖供与体の 5 位ヒドロキシ基の保護 基，ルイス酸，溶媒などを種々検討したが，高い $\beta$ 選択性は認められなかった。

$\mathrm{P}_{2} \mathrm{Y}_{1}$ 受容体拮抗薬を指向する A3P5P の構造展 

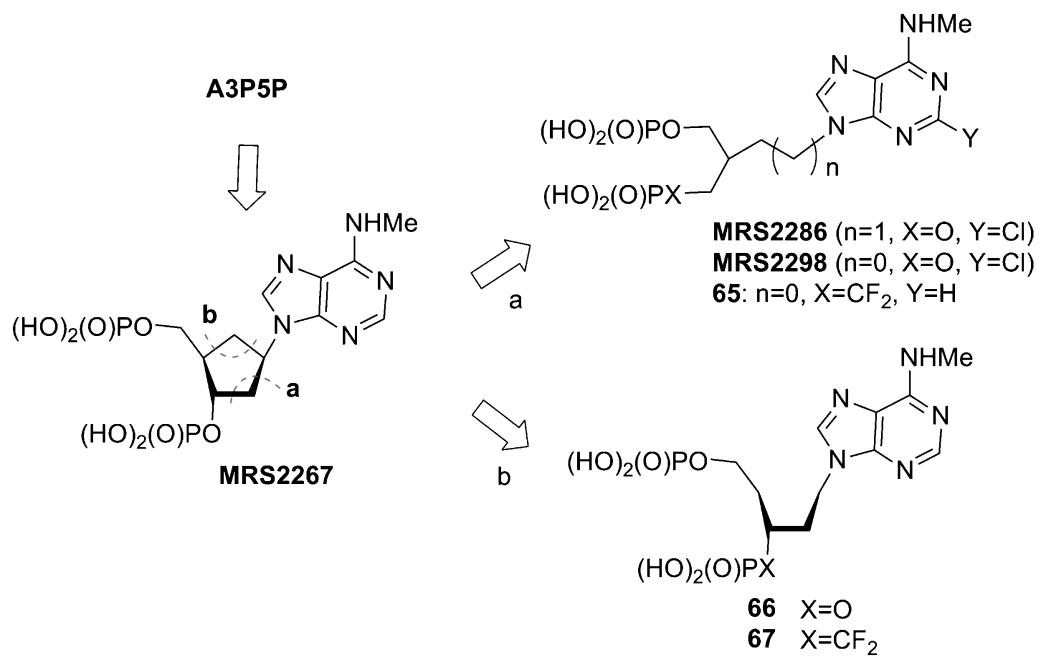

Fig. 5. Modification of A3P5P to Improve Antagonist Activities against $\mathrm{P}_{2} \mathrm{Y}_{1}$ Receptor

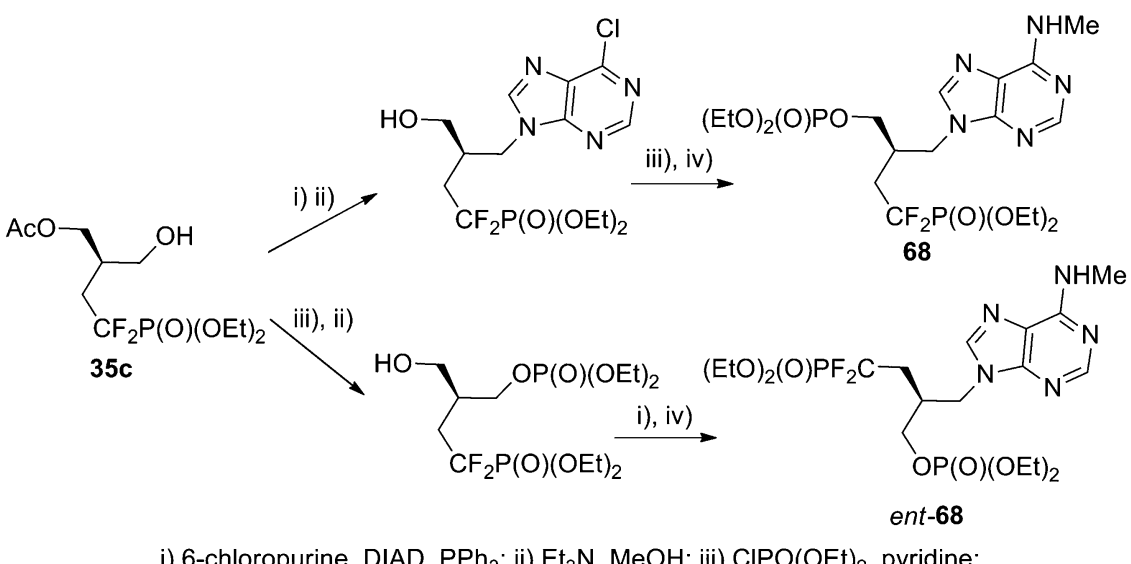

i) 6-chloropurine, $\mathrm{DIAD}, \mathrm{PPh}_{3}$; ii) $\mathrm{Et}_{3} \mathrm{~N}, \mathrm{MeOH}$; iii) $\mathrm{CIPO}(\mathrm{OEt})_{2}$, pyridine; iv) $2.0 \mathrm{M} \mathrm{MeNH}_{2}-\mathrm{MeOH}$

Scheme 18. Synthesis of Open Chain Analogues for MRS2267 (1)

開において，糖部を炭素環に変更したアナログ (MRS2267)，及び，破線 a 部分で開環した非環式 アナログ（MRS2286, MRS2298）などにも，高い アンタゴニスト活性が認められていた（Fig. 5). ${ }^{73)}$ そこで, 筆者は, MRS2298 のリン酸エステルの 1 つをジフルオロメチレンホスホン酸で置換した安定

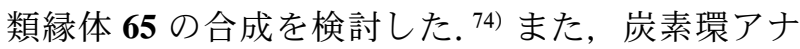
ログ（MRS2267）の炭素環を破線 b 部分で開環し たアナログ 67 についても，あわせて合成法を検討 した. ${ }^{75)}$

非環式アナログ 65 及びそのエナンチオマー ent-65 のエステル保護体（68 及び ent-68）は, Scheme 18 に示すように, 前述した光学活性モノア セテート 35c を合成素子として利用すると, 高収率

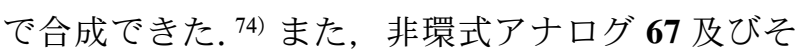

のエナンチオマー ent-67 のエステル保護体（73 及 び ent-73）は，ホスホノチオエート型ラクトン 59b の還元的開環反応を経由して合成した共通合成中間 体 71 から， Scheme 19 に示す官能基変換反応を組

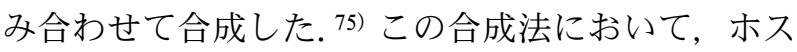
ホナート型ラクトン 56b の還元的な開環反応は, ホスホナート基の分解が観察され, 不成功であつ た. 本合成法において，ホスホナート基の安定性を 増す方法として, ホスホノチオエート基への変換が 有効であることが明らかとなった.

6. ホスフィニルジペプチドイソスターの立体制 御合成

6-1. 素反応の開発 リン原子は， 3 価と 5 価 の原子価状態を取り得る第 15 族の元素であり, そ のオキソ酸は，いずれも 5 価のリン原子を中心とす 


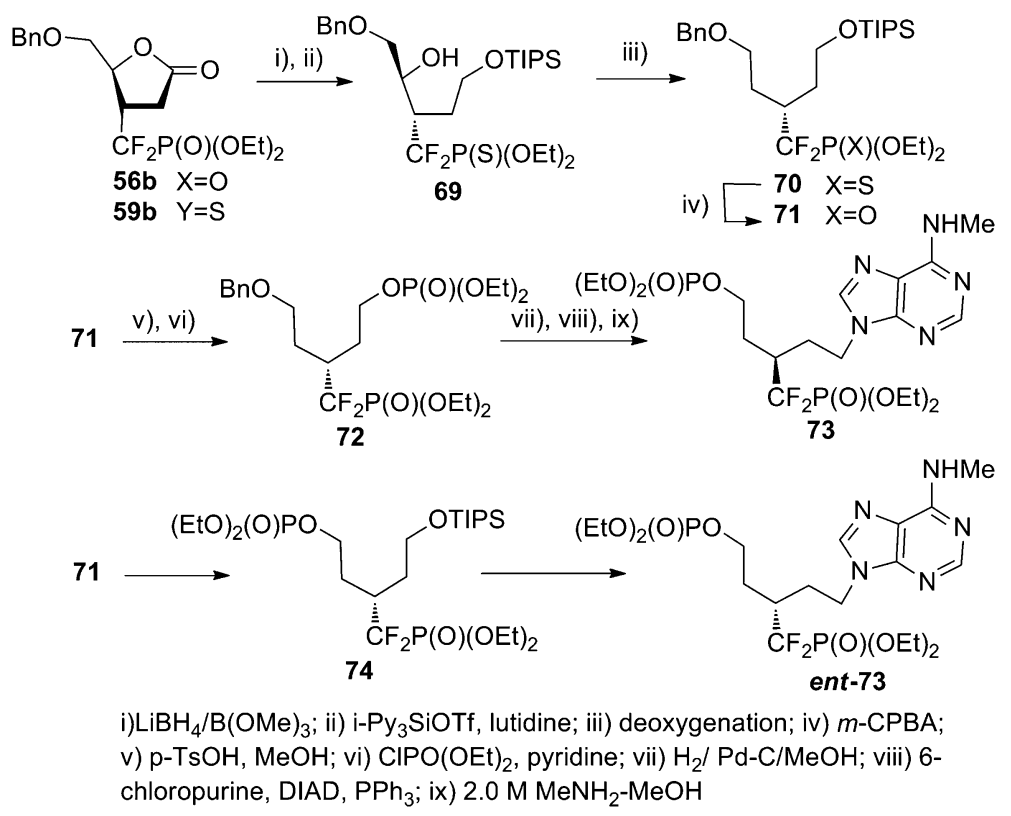

Scheme 19. Synthesis of Open Chain Analogues for MRS2267 (2)

るテトラへドラルな構造を有している. リン原子に 2 個のアルキル基が結合したオキソ酸はホスフィン 酸と呼ばれ，安定に存在できる。テトラヘドラルな ホスフィン酸の構造は，アルキル gem-ジオール構 造とよく似ている。このようなホスフィン酸誘導体 の構造的な特徵を利用して，不安定なアルキル gem-ジオール構造などを安定なホスフィン酸に置 き換えて，新しい生物活性化合物の創製に利用され るようになっている. ${ }^{76)}$

ホスフィニルジペプチドイソスター (PDIs) は, ジペプチドのアミド結合をメチルホスフィニル基で 置換したジペプチドイソスターで，ジペプチドが加 水分解されるときの水和遷移状態を模倣できる (Fig. 6). ${ }^{76)}$ PDIs を組み込んだオリゴペプチドは, レニンや $\beta$-セクレターゼなどのアスパラギン酸プ ロテアーゼの阻害剤として利用されている（Fig. 6). ${ }^{77-79)}$ また，ホスフィン酸は亜鉛に二座配位でき る性質を有するため，メタロプロテアーゼ阻害剤の 重要な部分構造にも利用されている. ${ }^{80}$

これまで，PDIs の $\alpha$ 位と $\beta^{\prime}$ 位の立体配置を制御 した合成法は知られていなかった．したがって，生 物活性を有する所望の立体配置を有するオリゴマー は，ジアステレオマー混合物として合成された PDIs をオリゴペプチドに組み込んだ後に分離する 方法により合成されていた，そこで，効率よい合成 法をめざして検討したところ，ホスフィニル基の不

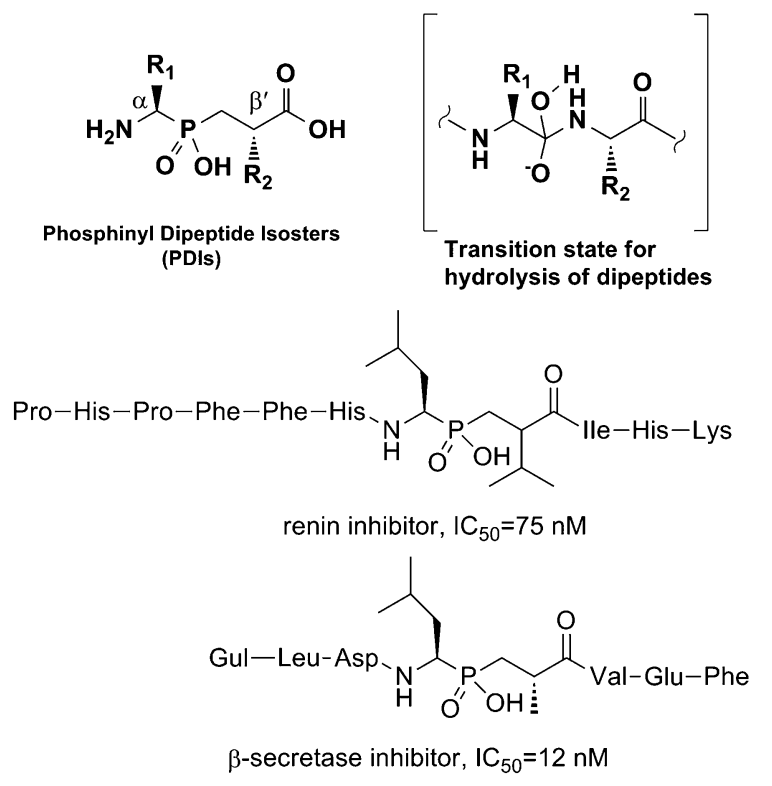

Fig. 6. Biologically Active Peptides Having a Phosphinyl Dipeptide Isostere

斉を有効に活用する PDIs の不斉合成法が開発でき た (Scheme 20). ${ }^{81-86)}$

すなわち， $\alpha$-アミノホスフィン酸誘導体 77 を低 温で LHMDS と処理し，生成するアニオンを求電 子剂で捕捉すると，79が高いジアステレオ選択性 （10:1-4.5:1）で生成した. ${ }^{82)} 78$ を基質に用いると 選択性が低下することから，高い選択性の発現に， アセタールの付け根のメチル基が重要な役割を演じ ていることが推定された（Fig. 7，A）。79は，窒素 

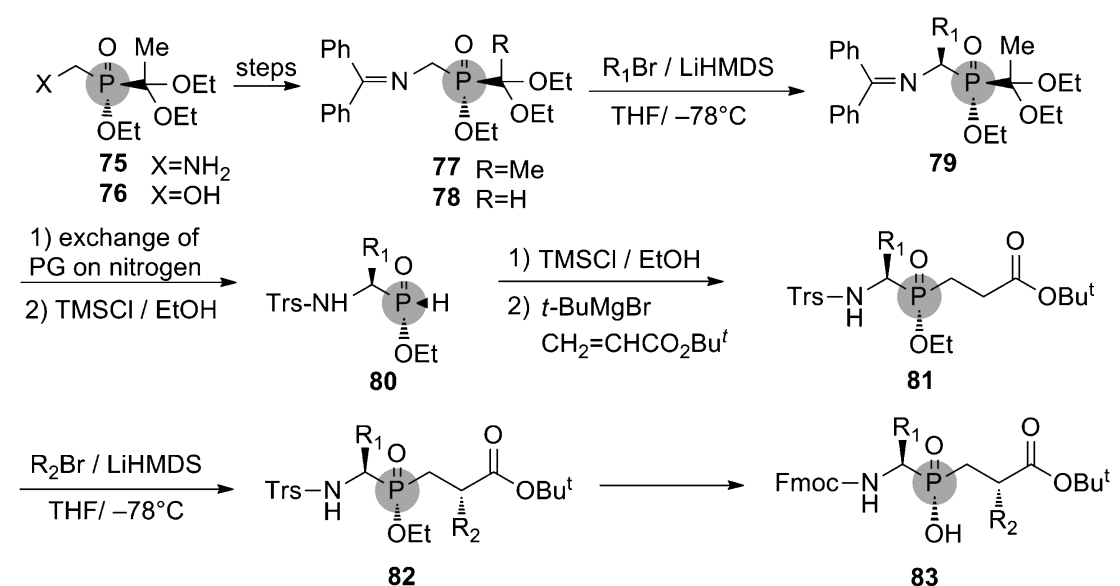

Scheme 20. Stereocontrolled Synthesis of PDIs

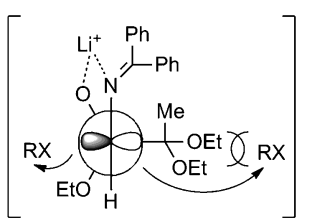

A

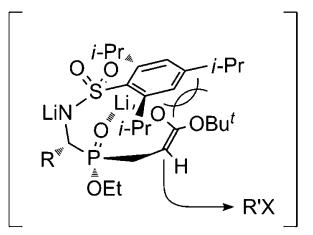

B

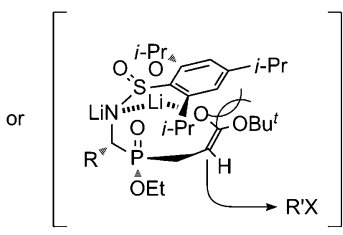

C

Fig. 7. Plausible Transition States for Stereoselctive Alkylation Reactions

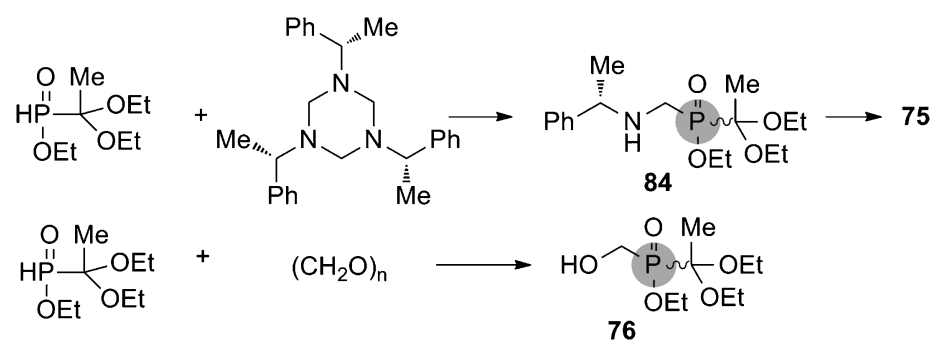

Scheme 21. Preparation of Starting Phosphinates

上の保護基を嵩高いトリシル基に変換後, 1,1-ジエ トキシエチル基を除去し，アミノ- $H$-ホスフィナー ト80 に変換した。 80 は，さらに，マグネシウム系 塩基の存在下で, アクリル酸 tert-ブチルを作用さ せると, PDIs の基本骨格 $\mathbf{8 1}$ が高収率で生成した。 以上の変換過程で, ホスフィニル基の立体配置は保 持されていた. 81 をLHMDS で処理し，生成する エノラートをハロゲン化アルキルで捕捉すると， $\alpha$ 位及び $\beta^{\prime}$ 位にアルキル基を有する 82 が高選択的 （25:1-14:1）に得られた。選択性の発現は，Fig. 7 に示した遷移状態 $\mathbf{B}$ あるいは $\mathbf{C}$ において, 親電 子剤が嵩高いトリシル基の逆側からエノレートに接 近することによると推定した。 82 は，オリゴペプ チドに誘導可能な Fmoc 体 83 に変換可能である. ${ }^{83)}$
なお，本合成法において，出発原料となるヒドロ キシメチルホスフィン酸誘導体 76 は, ラセミ体と して合成後, リパーゼ触媒を用いる不斉アシル化反 応により速度論的光学分割を行うと, 高純度なそれ ぞれの鏡像異性体が得られた（Scheme 21）。 ${ }^{84) ま ~}$ た, アミノメチルホスフィン酸誘導体 75 は, 光学 活性フェニルエチルアミンから得られるアミノホス フィン酸 84 のジアステレオマー混合物を分離する 方法で，両エナンチオマーを得ることができる (Scheme 21). ${ }^{85,86)}$ さらに, 82 は, 塩基で処理後, 生成するエノレートをプロトン化すると， $\beta^{\prime}$ 位の立

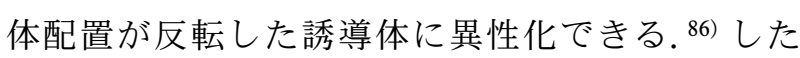
がって，本法は，以上の知見を組み合わせると， PDIs の 4 つのジアステレオマーを，それぞれ，光 

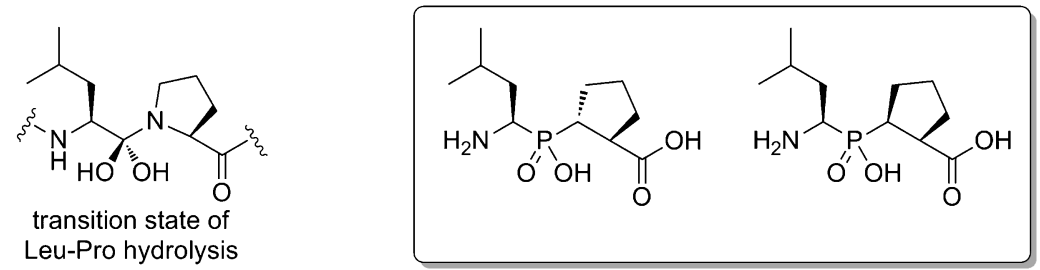

Fig. 8. PDIs for Leu-Pro Dipeptides
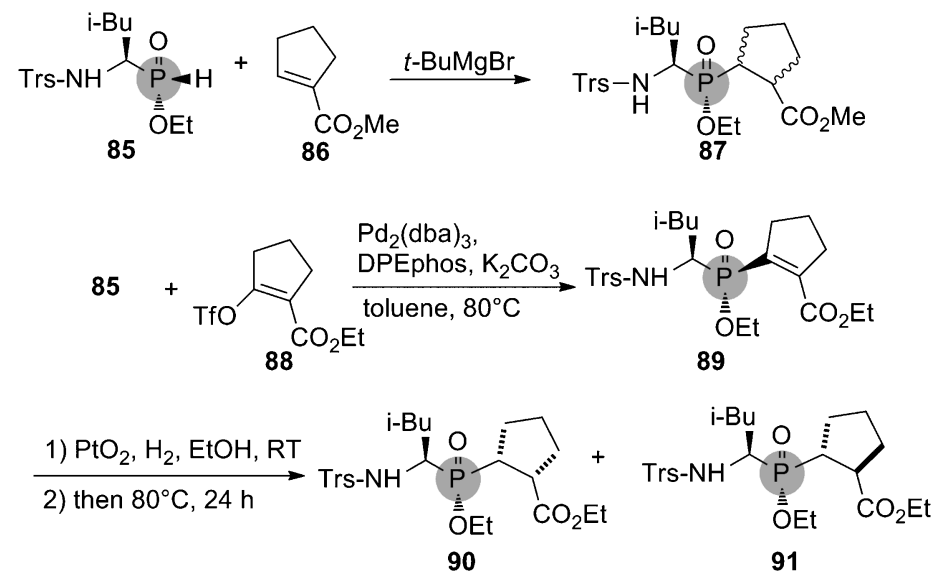

Scheme 22. Stereoselective Synthesis of PDIs for Leu-Pro Dipeptide

学活性体として作り分けることが可能である.

\section{6-2. Leu-Pro 型 PDIs の合成＼cjkstart成人 $\mathrm{T}$ 細胞白} 血病の発症に関与する human T-cell leukemia virus type 1 (HTLV-1) プロテアーゼなどある種のプロテ アーゼは，基質タンパク質の切断部位にロイシンと プロリンが含まれている（Fig. 8)。これらのプロ テアーゼを標的とするペプチド性プロテアーゼ阻害 剂のジペプチドイソスターとして，Leu-Pro 型 PDIs は有用と考えられる。 Leu-Pro 型 PDIs に は，ジペプチドの窒素原子の 1 つが炭素原子で置き 換えられているので, Fig. 8 に示すジアステレオ マーが存在する。したがった，Leu-Pro 型 PDIs の 合成では，高度な立体制御が必要となる，Leu-Pro 型 PDIs の合成例は極めて少なく二例しか報告され ていなかったが, これらのジアステレオマーの立体 選択合成には，成功していなかつた。 ${ }^{87,88)}$

筆者は，6-1. で述べた合成法を踏まえて，はじめ に，ホスフィン酸誘導体 85 と共役エステル 86 の Michael 反応を検討した. ${ }^{89)}$ しかし，生成物はジア ステレオマーの混合物として得られ，この反応のジ アステレオ選択性は認められなかった (Scheme 22).

そこで，次に，ホスフィン酸誘導体 85 とトリフ
ラート 88 のカップリング反応をパラジウム触媒と して $\mathrm{Pd}_{2}(\mathrm{dba})_{3}$ ，リガンドに DPEphos，塩基とし て $\mathrm{K}_{2} \mathrm{CO}_{3}$ を用いて行いカップリング生成物 89 を得 た (Scheme 22).このカップリング反応の過程で, リン原子の配位は完全に保持されていた。 得られた カップリング生成物 89 は, 酸化白金触媒下で水添 すると，90 と91 を生成比 $11: 1$ で与えた。主成績 体 90 の $\beta^{\prime}$ 位の配位は天然型とは異なっていた。し かし，加熱条件で水添すると，90 は天然型の立体 を有する91 へ完全に異性化することができた．本 合成法は，Leu-Pro 型 PDIs の立体制御合成に関す る，最初の報告例と考えられる. ${ }^{89)}$

なお，PDIs に関する以上の成果は，山岸丈洋元 講師（現在，奥羽大学薬学部教授）が本教室に在籍 中に行つた業績の 1 つである. 本業績は，山岸教授 の日本薬学会東北支部若手奨励賞の受賞対象となつ た. ${ }^{81)}$ 大変喜ばしいことである.

7. ジフルオロメチレンホスホン酸誘導体のメ ディシナルケミストリー

細胞外の情報が細胞内に伝達されて, 細胞の分 化，増殖及び細胞死などの細胞応答に変換される仕 組みは，細胞内情報伝達機構と呼ばれる，身体に存 
Table 1. Physical Propaties of Phosphates and Phosphonates

\begin{tabular}{|c|c|c|c|c|c|}
\hline \multirow{2}{*}{ Compd. } & \multirow{2}{*}{$\mathrm{X}$} & \multirow{2}{*}{ angle $\alpha$} & \multicolumn{2}{|c|}{ bond length (̊) } & \multirow{2}{*}{$\mathrm{p} K \mathrm{a}_{2}$} \\
\hline & & & $\mathrm{a}$ & $\mathrm{b}$ & \\
\hline 92 & $\mathrm{O}$ & $118.7^{\circ}$ & 1.59 & 1.43 & 6.4 \\
\hline 93 & $\mathrm{CH}_{2}$ & $112.1^{\circ}$ & 1.81 & 1.51 & 7.5 \\
\hline 94 & $\mathrm{CF}_{2}$ & $116.5^{\circ}$ & 1.85 & 1.50 & 5.6 \\
\hline
\end{tabular}

在する様々な細胞内情報伝達機構を統合した複雑な 生体システムが正しく働くことにより，心蔵，肝 臓，脳を始め，多くの臟器や組織が互いに正常に機 能し, 生命現象の恒常性が維持されている. 多くの 疾病の発症は情報伝達機構の不調に起因することが 明らかにされるようになり，それらを正しく制御す る物質が難治性疾患の治療薬や予防薬の創製に活用 されるようになった。

タンパク質，糖質，核酸などから生成する多くの 生体内リン酸エステルは, 細胞内の情報伝達機構で 重要な役割をしている. 生体内リン酸エステルの物 理化学的性質を保持したまま, 加水分解酵素に対し て安定な分子は，疾病と関連する細胞内情報伝達機 構を解明する探索分子（分子プローブ）となるばか りか, 情報伝達機構の破綻により生ずる疾病の治療 薬リードとなることが期待された。

ジフルオロメチレンホスホン酸 94 (以下 DFMPA と略す）は，リン酸エステル 92 のエステル酸素を ジフルオロメチレン $\left(\mathrm{CF}_{2}\right)$ で置換した誘導体で, R-C-P の結合角と第二酸解離定数 $\left(\mathrm{p} K \mathrm{a}_{2}\right)$ がリン 酸エステル 92 のそれらに近い值を示す（Table 1). ${ }^{8,9,90)}$ また，2つのフッ素原子は，水素結合のア クセプターとなることも報告されており, 91,92) リン 酸エステル 89 におけるエステル酸素原子の不対電 子をミミックすることができる。このような物理化 学的性質を有するため, DFMPA はメチレンホス ホン酸 93 よりもリン酸エステル 92 に物理化学的な 性質が似ている。筆者は，このような物理化学的な 性質に注目し，DFMPA 誘導体の簡易合成法とそ れを利用する生物活性化合物の創製について検討し た

7-1. ジフルオロメチレンホスホン酸（DFMPA） 誘導体の合成 筆者が研究を開始した当時, 既に, DFMPA 誘導体の合成法は数多く報告されてい
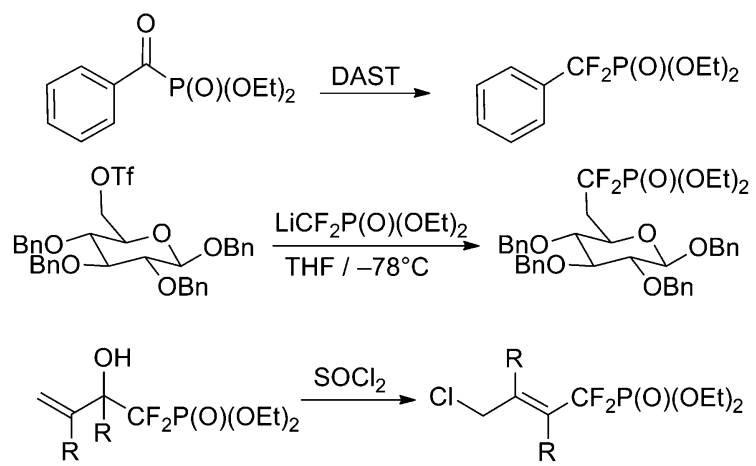

Scheme 23. Representative Reactions for Synthesis of DFMPA Ester Derivertives

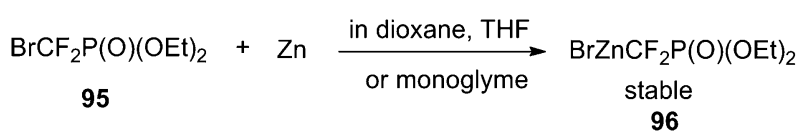

Scheme 24. Preparation of the Burton Reagent

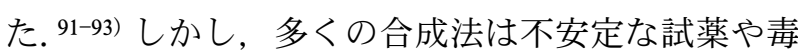
性の高い試薬を用いるなどの操作上の制限があり, 簡便な方法とは言えなかった（Scheme 23）。例え ば，ベンゼン核に DFMPA エステル基を導入する には，不安定なケトホスホネートを有毒な DAST で処理する方法が利用されていた [Eq. (1) ] . ${ }^{94-96)}$ アルキル鎖に DFMPA エステル基を導入するため には，不安定なトリフラートを低温で $\mathrm{HCF}_{2} \mathrm{P}(\mathrm{O})$ $(\mathrm{OEt})_{2}$ のリチウム塩 ${ }^{97)} \quad\left[\mathrm{LiCF}_{2} \mathrm{P}(\mathrm{O})(\mathrm{OEt})_{2}\right]$ で処理 する方法が利用されていた [Eq. (2) ]. ${ }^{98-100)} \mathrm{LiCF}_{2}$ $\mathrm{P}(\mathrm{O})(\mathrm{OEt}){ }_{2}$ は， $-78^{\circ} \mathrm{C}$ 以上に昇温するとジフルオ ロカルベン $\left(: \mathrm{CF}_{2}\right)$ と $\mathrm{LiP}(\mathrm{O})(\mathrm{OEt})_{2}$ に分解し, 取 扱が困難であった。 また，立体障害の大きい 2 級卜

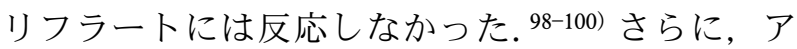
ルケンへの DFMPA エステルの導入は，アリルア ルコールの転位反応を利用する間接的な方法が 1 例 知られているのみであった [Eq. (3)]. ${ }^{101)}$

安定で毒性の低い試薬を用いる DFMPA 誘導体 の合成法を調査したところ, エーテル系溶媒中でブ ロモ試薬 95 と亜鉛から調製される亜鉛試薬 96 は, 熱的安定性が高く，取扱が容易な有機金属試薬であ ることが Burton らにより報告されていた（Scheme 24). ${ }^{102)} 96$ は, $\mathrm{CuBr}$ 存在下で臭化ベンジル，臭化 アリルなどの親電子剂と室温で容易に反応し，対応 する DFMPA 誘導体を与えることも報告されてい た。しかしながら， $\mathrm{sp}^{2}$ 炭素や $\mathrm{sp}$ 炭素に DFMPA 


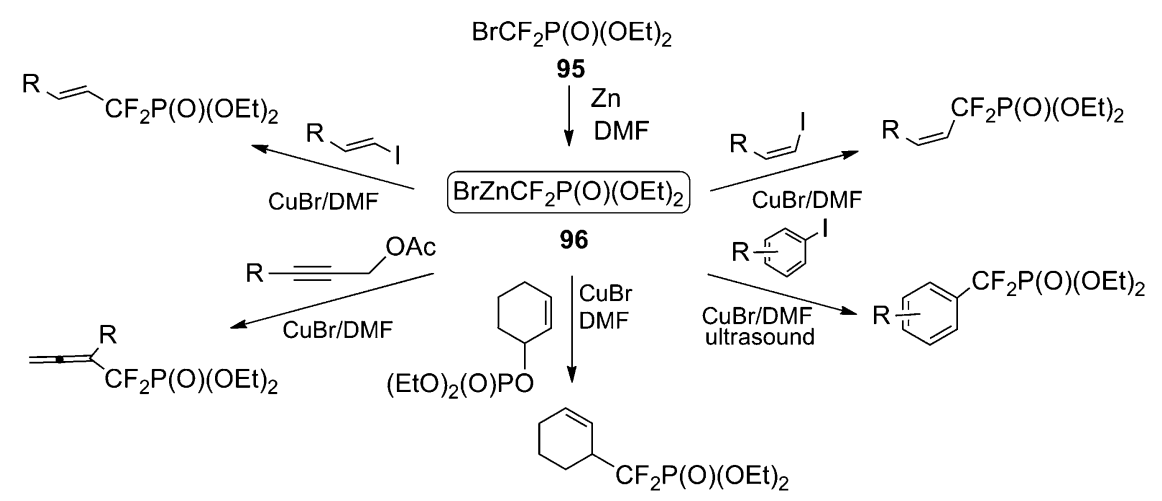

Scheme 25. Versatile Reactivity of the Burton Reagent in DMF

エステルを直接導入するカップリング反応への展開 はほとんど検討されていなかった.

そこで，筆者は，Burton 試薬の適用範囲を拡張 するために，溶媒効果を検討した（Scheme 25）. その結果, DMF 系溶媒中で調製した亜鉛試薬 96 を，触媒量の $\mathrm{CuBr}$ 存在下ヨードアルケン類と処理 すると，立体特異的にカップリング反応が進行し二 重結合にDFMPA エステル基を直接導入できるこ とが明らかとなった. ${ }^{103)}$ また， ヨードベンゼン誘 導体との反応では，等量の $\mathrm{CuBr}$ と超音波の照射が 必要であったが, ベンゼン環に DFMPA エステル を直接導入することに成功した. ${ }^{104)}$ 以上の反応は, $\mathrm{sp}^{2}$ 炭素に DFMPA エステル基を簡便に直接導入し た最初の報告例となった。 その他, DMF 系溶媒中 で調製した亜鉛試薬 96 は，環状アリルホスフェー トやプロパギルアセテートと $\mathrm{CuBr}$ 存在下容易に反 応し，アリル位及びアレンの $\mathrm{sp}^{2}$ 炭素に DFMPA エステルを簡便に導入することができた. ${ }^{105,106)}$

本カップリング反応を利用すると, DFMPA エ ステル基を有する 1,3-ジエン 97 の合成が可能で,

Diels-Alder 反応を組み合わせると，合成が比較的 困難なシクロヘキセン誘導体 $\mathbf{9 8}$ が立体選択的に合 成できた（Scheme 26）。107)さらに，DFMPA エス テルと共役したアルケン類 99 は, 優れたラジカル 受容体となり，テトラヒドロフラン及びピラン誘導 体 100 の簡易合成に利用できた（Scheme 27）。 108,109) 100 は 101 に立体選択的に変換可能である。 また, カップリング反応で合成された DFMPA エステル $\boldsymbol{E}-102$ を, $\mathrm{Pd}(\mathrm{OAc})_{2}$ 存在下, ジアゾメタンと反応 させると，シクロプロパン環に DFMPA エステル 基が直結された誘導体 103 の合成が可能であっ

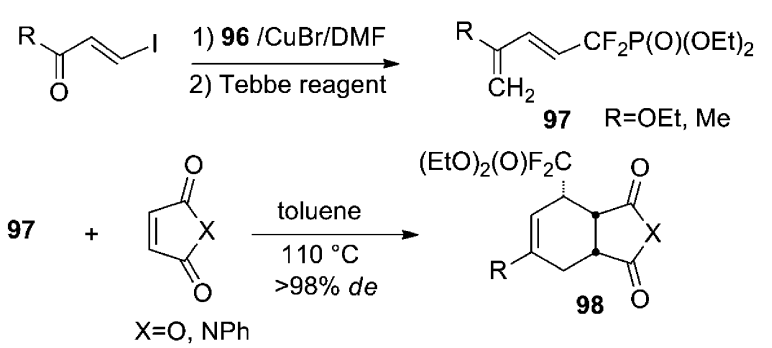

Scheme 26. Introduction of DFMP Ester to Cyclohexene Moiety

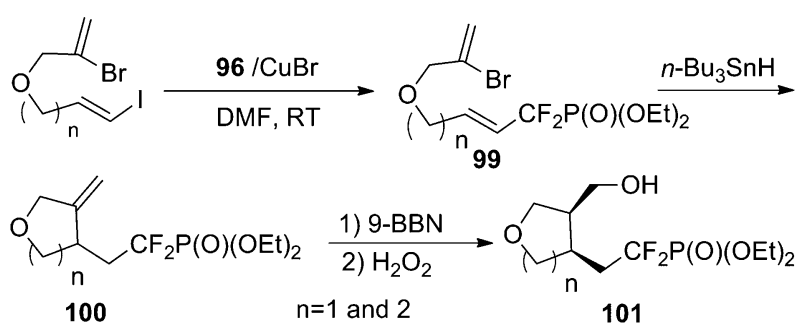

Scheme 27. Reactivity of Alkenyldifluoromethylphosphonates toward Vinyl Radicals

た. 110-113) 103 は, 共役エステル 104 のイオウイリ ドを利用するシクロプロパン化反応を経由する方法 でも合成可能であった (Scheme 28).112)また， シ クロパン誘導体 103 は, リパーゼ触媒下の不斉アシ ル化反応により光学分割が可能で, 高純度の両エナ ンチオマーを合成することができる. ${ }^{110)} 101$ 及び 103 は, 後述するプリンヌクレオシドホスホリラー ゼ (PNP) 阻害剤の構造活性相関研究の合成中間 体として利用された。

前述したように, ベンゼン環に DFMPA エステ ルを簡便に導入することができたので, 本法をリン 酸化チロシン（p-Tyr）のエステル酸素をジフルオ 


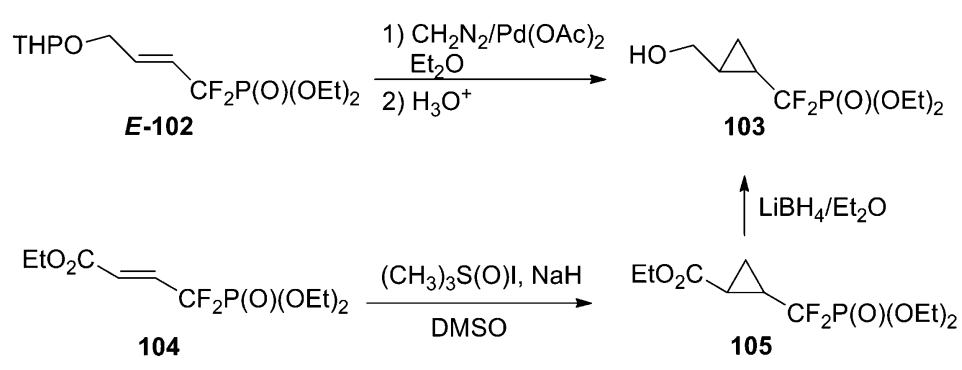

Scheme 28. Cyclopropanation of Alkenyldifluoromethylphosphonates

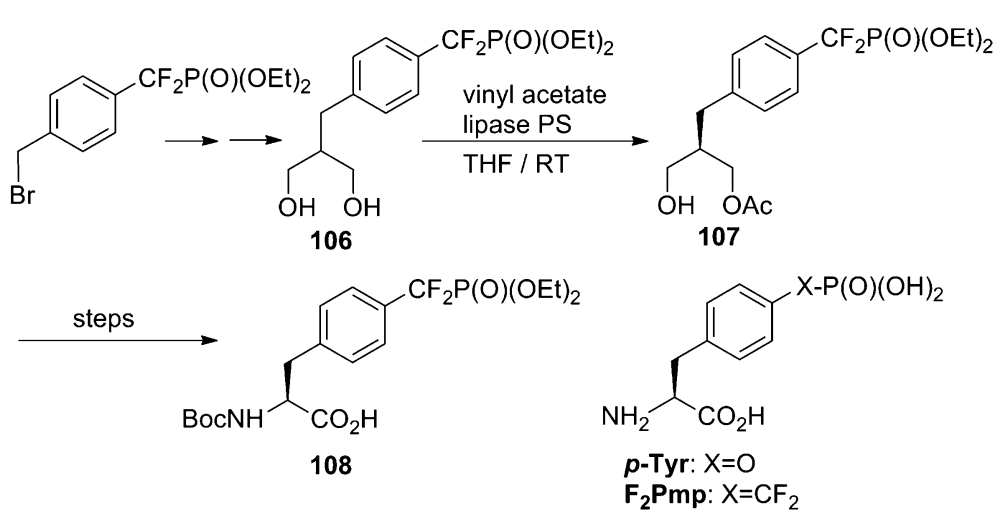

Scheme 29. Synthesis of $\mathbf{F}_{2} \mathbf{P m p}$ Derivertives

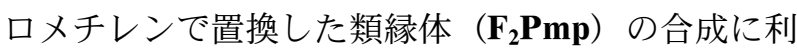
用した (Scheme 29). ${ }^{114)} \mathbf{F}_{2} \mathbf{P m p}$ は，後述するプロ ティンチロシンホスファターゼ (PTP) のペプチ ド性阻害剂の構成アミノ酸として注目され，数種の 合成法が報告されていた. ${ }^{91-93)}$ 筆者らは，カップリ ング反応を利用して容易に合成できるジオール 106 のリパーゼ触媒下の不斉アシル化反応を検討したと ころ, 非対称化が高選択的に進行しモノアセテート 107 が高純度で得られた。107 は，ペプチドに誘導 可能な $F_{2} P m p$ 誘導体 108 に変換された. ${ }^{114)}$

また, Otaka らは, リン酸化スレオニン（p-Thr） のエステル酸素をジフルオロメチレンに置換した類 縁体 $\mathbf{F}_{2} \mathbf{P m b a}$ の合成に，ヨードアルケン 109 と亜鉛 試薬 96 のクロスカップリング反応を利用している (Scheme 30)。115) カップリング生成物は不斉補助基 を有する共役エステル 110 に変換後，不斉還元を経 て 111 に誘導された。 111 は，選択的な $\alpha$ 位アミノ 化反応により $\mathbf{L}-\mathbf{F}_{2} \mathbf{P m b a}$ deriv. に変換された。 L$\mathrm{F}_{2}$ Pmba deriv. は, $p$-Thr の安定類縁体としてシグ ナルペプチドに取り込むことができる.

7-2. ジフルオロメチレンホスホノチオ酸 （DFMPTA）の合成と物性＼cjkstart前節で述べたジフル
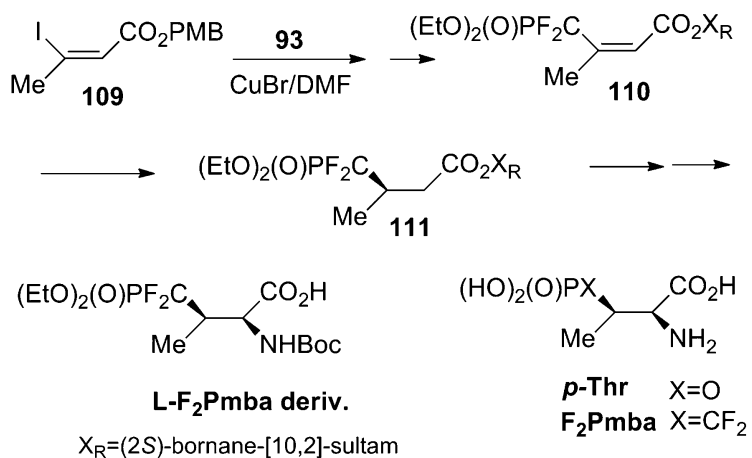

Scheme 30. Application of the Cross Coupling Reaction to the Synthesis of $\mathbf{L}-\mathbf{F}_{2}$ Pmba Deriv.

オロメチレンホスホン酸 [DFMPA, $\mathrm{R}-\mathrm{CF}_{2} \mathrm{P}(\mathrm{O})$ $\left.(\mathrm{OH})_{2}\right]$ は，極性の高さから，細胞膜の透過性が低 く，細胞内に取り込まれ難いことが予想された。そ こで，疎水性の向上を目的に，DFMPAのリンー酸 素二重結合をリンーイオウ二重結合に置き換えた類 縁体，すなわち，ジフルオロメチレンホスホノチオ 酸 [DFMPTA, R- $\left.\mathrm{CF}_{2} \mathrm{P}(\mathrm{S})(\mathrm{OH})_{2}\right]$ の合成を検討 した．特に，後述するプロティンチロシンホスファ ターゼ阻害剤の創製をも念頭において，芳香族 DFMPTAの合成を検討した (Scheme 31). 116,117) 


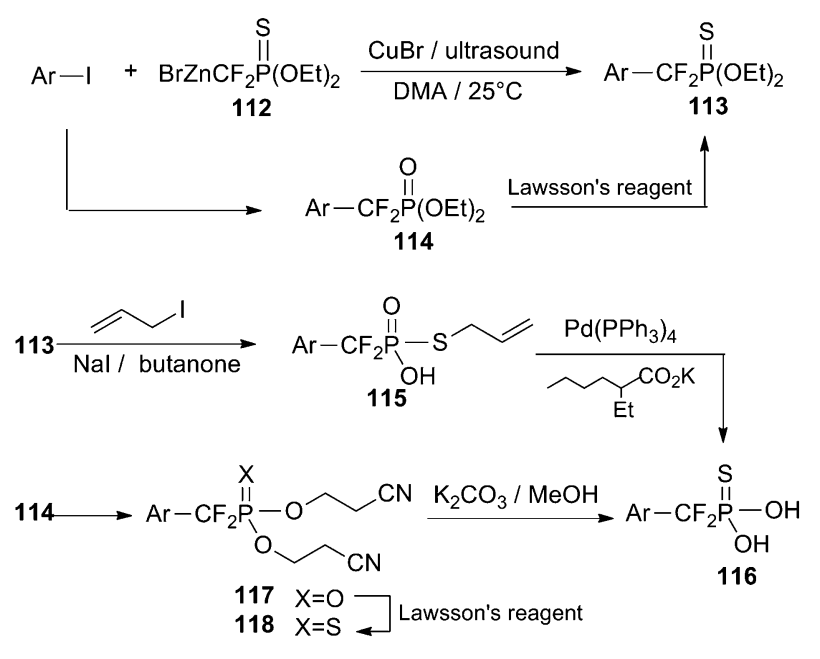

Scheme 31. Synthesis of Aryldifluoromethylphosphonothioic Acids

DFMPTA エステル基の芳香核への導入は，1） 対応するブロマイドから調製した亜鉛試薬 112 と ヨードアリール類の臭化銅存在下のカップリング反 応で直接得る方法，2）ヨードアリールからカップ リング反応で得られるDFMPA エステル誘導体 114 をチオ化する 2 段階で得る方法を検討し た. ${ }^{116,117)}$ 1）の方法は，カップリング生成物 113 の 収率（10-34\%）が低く実用的ではなかった。しか し，2）の方法では，チ才化剤として Lawesson's 試 薬を用いると，高収率で DFMPTA エステル 113 が 得られた.

DFMPA の合成と物性については古くから知ら れているが, ${ }^{90)}$ DFMPTA の物性については，ほと んど報告がなかった。そこで，次に，DFMPTA工 ステル 113 の脱エステル化を検討した。DFMPA エステル 114 は, 通常, $\mathrm{TMSBr}$ で処理後, 中間体 をメタノールなどで加溶媒分解すると容易に遊離酸 に変換できる，しかしながら，DFMPTA エステル 113 は，この条件で脱エステル化すると，複雑な混 合物を与え，遊離酸は得られなかった。

そこで，種々の脱エステル化を試みた。 113 は， ヨウ化ナトリウム存在下，3-ヨードプロペンと加熱 すると, thiono-thiolo 転位反応が高収率で進行し, $S$-アリルエステル 115 に変換された。 115 は 0 価パ ラジウムで処理するとアリル基が除去され，遊離酸 116 を与えた. ${ }^{116)}$ また, DFMPA エステル 114 は, 2-シアノエチル基にエステル交換後，Lawesson's 試薬でチオ化して DFMPTA エステル 118 に誘導し
Table 2. Physical Constants of $\mathbf{1 1 9}$ and $\mathbf{1 2 0}$

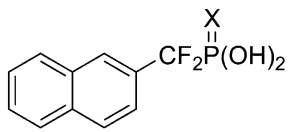

\begin{tabular}{cccc}
\hline \hline Compd. & $\mathrm{X}$ & $D$ & $\mathrm{p} K \mathrm{a}_{2}$ \\
\hline $\mathbf{1 1 9}$ & $\mathrm{O}$ & 0.18 & 5.4 \\
$\mathbf{1 2 0}$ & $\mathrm{S}$ & 0.82 & 4.5 \\
\hline
\end{tabular}

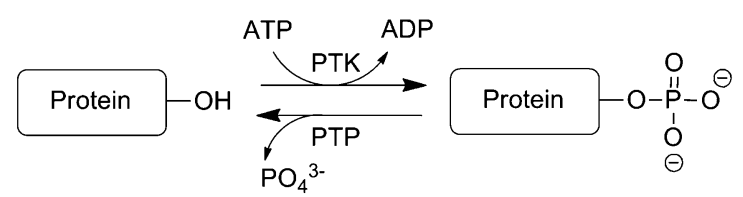

Fig. 9. Reversible Reactions Catalyzed by PTK and PTP

た，118 は，塩基で処理すると，遊離酸 116 に高収 率で変換できた. ${ }^{117)}$

DFMPA と DFMPTA の物性を比較するために, ナフタレン誘導体 119 と 120 について，オクタノー 儿/水分配比 $(D)$ 並びに第二酸解離定数 $\left(\mathrm{p} K \mathrm{a}_{2}\right)$ を求めた（Table 2). ${ }^{117)}$ ホスホン酸 119 の $D$ 值は $25^{\circ} \mathrm{C}$ において 0.18 と算出され，119 はほとんどオ クタノール層に分配されていないことが推定され た。一方，ホスホノチオ酸 120 の $D$ 值は 0.82 と算 出され，120 はオクタノール層と水層にほぼ $1: 1$ の割合で分配されていることが明らかとなった。

119 と 120 の $\mathrm{pKa}_{2}$ 值は，それぞれ，5.4，4.5 と算 出された. 以上のデータから, DFMPTA は DFMPA と同様に生理的 $\mathrm{pH}$ で解離し, 疎水性が高く, 細胞 内に効率よく浸透できる分子となることが期待され た.

7-3. プロティンチロシンホスファターゼ（PTP） 阻害剤の創製 チロシンキナーゼ内在型受容体を 介するシグナル伝達機構において，受容体に増殖因 子などが結合すると，その刺激は，多段階の信号変 換ステップを踏みながら核へと伝播され，最終的に は核で遺伝子の制御を介して，多様な生物応答を引

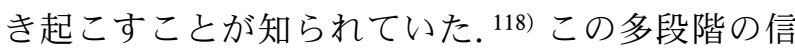
号変換ステップを制御している酵素に, プロテイン チロシンキナーゼ（PTK）とプロテインチロシン ホスファターゼ (PTP) がある (Fig. 9).

Figure 10 に模式的に示すように，この伝達機構 において，受容体の細胞外ドメインに増殖因子など が結合すると，受容体の構造変化（二量化）に伴つ 


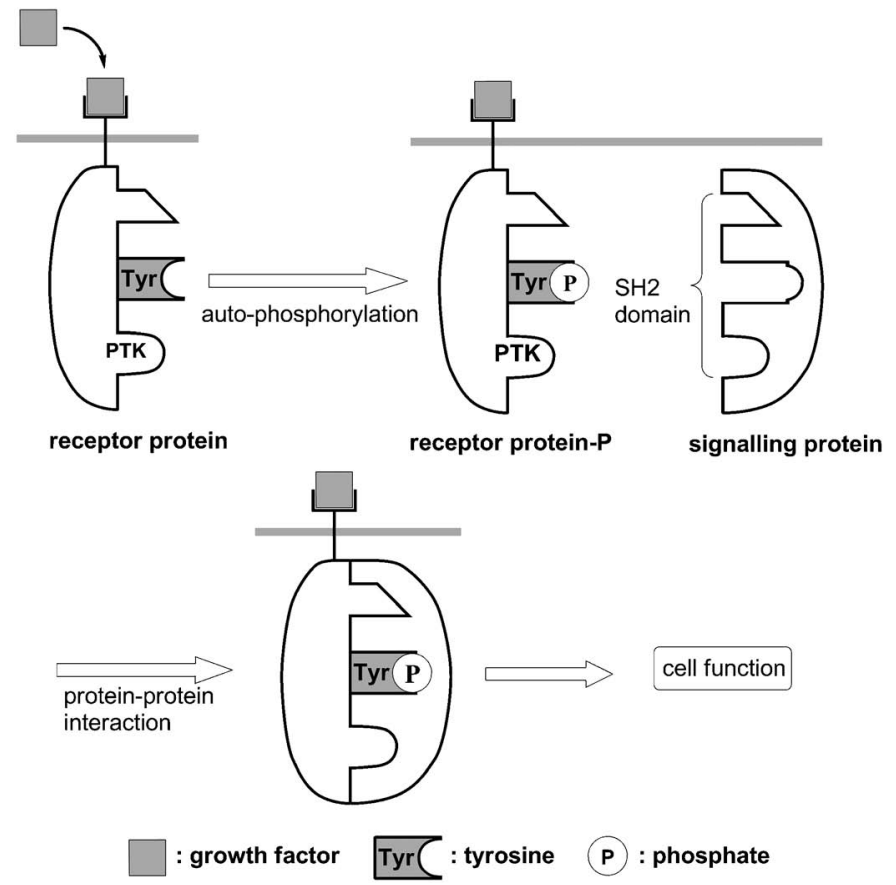

Fig. 10. Schematic Illustration of Tyrosine Kinase-mediated Signal Transductions

て PTK ドメインが活性化し，受容体のチロシン残 基は自己リン酸化を受ける。この情報は，リン酸化 された受容体タンパク質とリン酸化チロシン（ $p$ Tyr）残基を認識するアダプター分子などのシグナ ルタンパク質群との間に, タンパク質ータンパク質 相互作用が起き，核に伝達される。PTP は，リン 酸化された受容体タンパク質の $\boldsymbol{p}$ - Tyr を特異的に脱 リン酸化する酵素で，PTK と PTP の拮抗作用のバ ランスは, 細胞の恒常性の調節に大きな役割を果た していると考えられていた（Fig. 9).

形質転換した細胞には, $p$-Tyr の含量が異常に高 く, PTP の酵素活性と細胞のがん化に深い関係が あることが示唆されていた. ${ }^{118)}$ 一方，血管新生促 進因子受容体の多くがチロシンキナーゼ内在型であ り，PTKによるチロシンのリン酸化は血管新生を

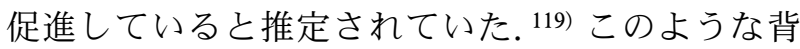
景から，PTP 阻害剂は，がん化や血管新生のメカ ニズム解明のための分子プローブになると考えられ た。しかしながら，筆者が研究を開始した当時，バ ナジン酸ナトリウムや酸化フェニルヒ素などに PTP の阻害活性が報告されていたが，分子プロー ブとして利用可能な低分子化合物はほとんど報告さ れていなかった。

7-3-1. PTP 阻害剂の探索そこで，筆者はリ

$$
\begin{gathered}
\text { Ac-Asp-Ala-Asp-Glu- Xxx }- \text { Leu }-\mathrm{NH}_{2} \\
121 \\
\mathbf{X x x}=\mathrm{F}_{2} \text { Pmp } \\
K_{\mathrm{i}}(\text { for PTP-1 })=0.18 \pm 0.02 \mu \mathrm{M}
\end{gathered}
$$

Fig. 11. A Peptidyl Inhibitor against PTP-1B

ン酸化チロシンの安定類縁体を基盤とする PTP 阻 害剂の探索を行つた。当時，このような手法による PTP 阻害剤の探索研究として, Burke らの先行研 究が知られていた. ${ }^{120-124)}$ Burke らは，PTP-1B の基 質となるリン酸化タンパク質のアミノ酸配列に注目 して， $\mathbf{F}_{2} \mathbf{P m p}$ を組み込んだオリゴペプチド $\mathbf{1 2 1} に$ ラット胎盤由来の PTP-1B に対する強い阻害活性 を見い出していた（Fig. 11）. 120) また，121 の非ぺ プチド化を展開する過程で, ナフタレンの $\beta$ 位に DFMPA 基を有する化合物 119 に，弱い PTP-1B

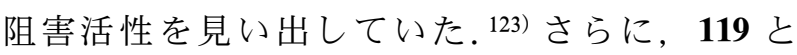
PTP-1B の共結晶の $\mathrm{X}$ 線結晶構造解析が報告され ていた (Fig. 12). 123,124)

この報告では，119は，DFMPA 基が予想通りリ ン酸結合部位に結合している以外に，ナフタレンの B 環がリン酸結合部の近傍の Phe182, Tyr46, Ile219 残基から構成される疎水性部分と $\pi$ スタキング型 の相互作用をしていることが明らかとされていた. 


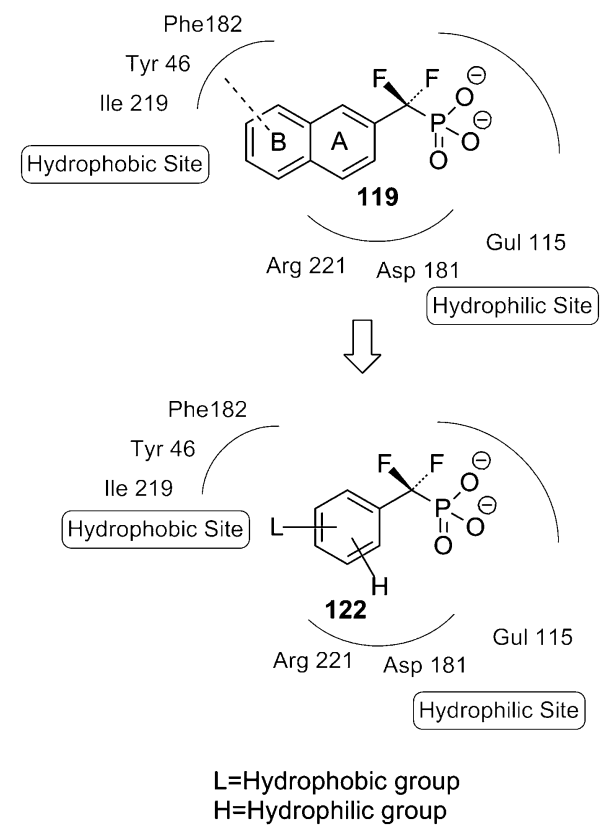

Fig. 12. Design for PTP Inhibitors Based on Phenyldifluoromethylphosphonic Acids

しかしながら, Gul115, Asp181, Arg221 残基から 構成される親水部分との相互作用は，観察されてい なかった。

筆者は，構造展開の多様性を踏まえて，フェニル ジフルオロメチルホスホン酸を基本構造に位置づけ, フェニル核に，疎水基 $(\mathrm{L})$ と水素結合アクセプター 基（H）を配置した誘導体 122 を設計した（Fig. 12). ${ }^{125,126)}$ 具体的には，DFMPA 基のメ夕位あるい はパラ位にフェニル基などの疎水基を導入した誘導 体 $\boldsymbol{m}$-123a-d 及び $\boldsymbol{p}-\mathbf{1 2 3 a}-\mathbf{d}$ を合成・評価した（Table 3)。 また，アクセプター（H）としての機能を 期待して，DFMPA 基のメ夕位にスルホンアミド 基及びビススルホンイミド基を配置し，さらに DFMPA 基のパラ位にスチリル基などの疎水基を
配置した誘導体 124a,b 及び 125a,b をそれぞれ合 成・評価した（Table 4)。これらの誘導体の合成で は，ブロムヨードベンゼン誘導体（126 と 129）と $\mathrm{BrZnCF}_{2} \mathrm{P}(\mathrm{O})(\mathrm{OEt}){ }_{2}$ の銅触媒下のカップリング反 応 ${ }^{104)}$ により 127 及び 130 を選択的に得た後, Still カップリング反応により疎水基を導入する方法が効 果的であった (Scheme 32). 125,126)

PTP-1B の阻害活性の測定は $p$-ニトロフェニルホ スフェート（ $p$-NPP） を用い，PTP-1B が $p$-NPP を加水分解する反応を $50 \%$ 阻害する被験化合物の 濃度を $\mathrm{IC}_{50}$ 值として表し，評価した。

陽性対照薬としたナフタレン誘導体 119 の $\mathrm{IC}_{50}$ 值は $718.1 \mu \mathrm{M}$ であるのに対し，ここで合成した誘 導体はすべて 119 と同等あるいはそれよりも高い PTP-1B 阻害活性を示した. ${ }^{125,126)}$ フェニルエチニル 誘導体（123b）では $m$-置換， $p$-置換で活性にほと んど変化がみられなかったが，概して $m$-置換体が $p$-置換体よりも活性が高い傾向があると言える．置 換基の種類ではエチニル基が最も高い活性を示し， $m$-エチニル誘導体 $\boldsymbol{m}$-123d $の ~ \mathrm{IC}_{50}$ 值は $19.0 \mu \mathrm{M}$ で あった。残念なことに, $\boldsymbol{m - 1 2 3 d}$ は安定性が低く, 活性の再現性がそしかった。 $p$ 位あるいは $m$ 位に $(E)$-スチリル基やフェニル基を導入した誘導体も 119 と同程度の PTP-1B 阻害活性を有していること が明らかになった。

フェニルエチニル誘導体 $\boldsymbol{p}$-123b にモノスルホン アミド基を導入すると阻害活性はむしろ低下した が，ビススルホンアミド基を導入すると $\boldsymbol{p - 1 2 3 b よ ~}$ り活性が向上する傾向がみられた。（E)-スチリル 誘導体 $\boldsymbol{p}$-123a にモノスルホンアミド基あるいはビ ススルホンアミド基を導入した誘導体（124a 及び 125a）は，活性が顕著に向上した．このことから，

Table 3. $\mathrm{IC}_{50}$ Values of Phenyldifluoromethylphosphonic Acid Derivertives against PTP-1B

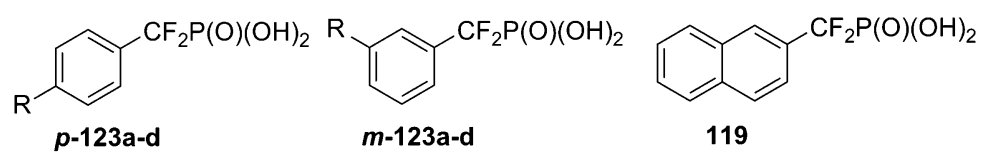

$\mathrm{IC}_{50}(\mathrm{PTP}-1 \mathrm{~B})=718.1 \mu \mathrm{M}$

\begin{tabular}{ccc|ccc}
\hline \hline Compound & $\mathrm{R}$ & $\mathrm{IC}_{50}, \mu \mathrm{M}$ & Compound & $\mathrm{R}$ & $\mathrm{IC}_{50}, \mu \mathrm{M}$ \\
\hline $\boldsymbol{p}$-123a & $(E)$-styryl & 449.9 & $\boldsymbol{m}$-123a & $(E)$-styryl & 386.2 \\
$\boldsymbol{p}$-123b & phenylethnyl & 128.3 & $\boldsymbol{m}$-123b & phenylethnyl & 135.9 \\
$p$-123c & phenyl & 778.9 & $\boldsymbol{m}$-123c & phenyl & 252.2 \\
$\boldsymbol{p}$-123d & ethnyl & 77.5 & $\boldsymbol{m}$-123d & ethnyl & 19.0 \\
\hline
\end{tabular}


Table 4. Effects of Sulfonamides and Bis-sulfonimides on Inhibition against PTP-1B
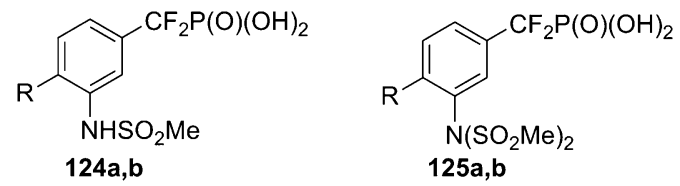

\begin{tabular}{ccc|ccc}
\hline \hline Compound & $\mathrm{R}$ & $\mathrm{IC}_{50}, \mu \mathrm{M}$ & Compound & $\mathrm{R}$ & $\mathrm{IC}_{50}, \mu \mathrm{M}$ \\
\hline $\mathbf{1 2 4 a}$ & $(E)$-styryl & 175.7 & $\mathbf{1 2 5 a}$ & $(E)$-styryl & 57.9 \\
$\mathbf{1 2 4 b}$ & phenylethnyl & 167.1 & $\mathbf{1 2 5 b}$ & phenylethnyl & 88.7 \\
\hline
\end{tabular}
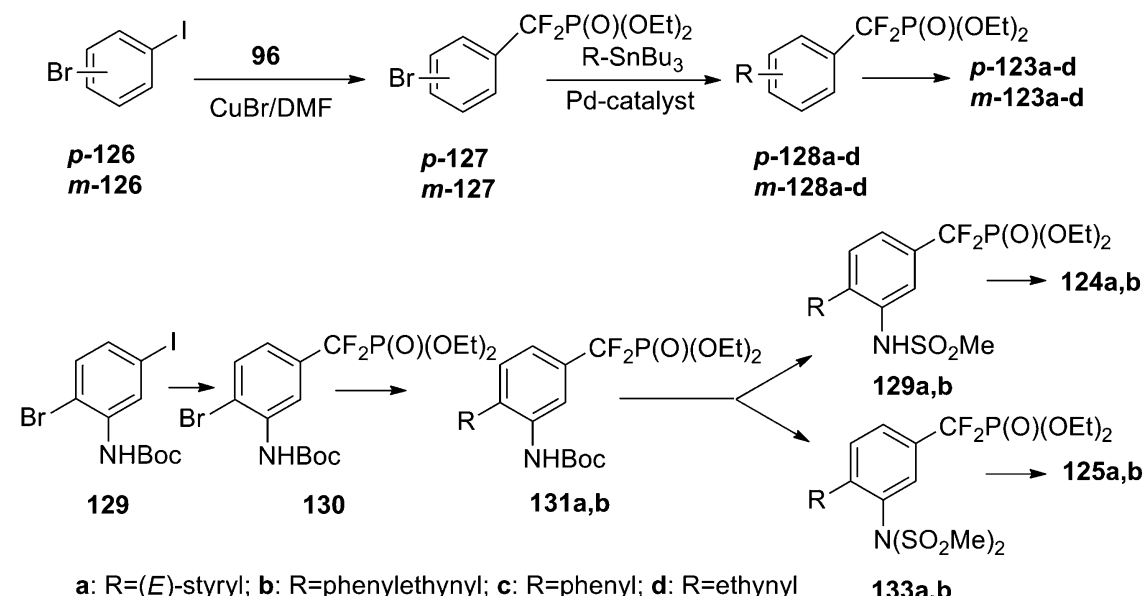

a: $\mathrm{R}=(E)$-styryl; $\mathbf{b}: \mathrm{R}=$ phenylethynyl; $\mathbf{c}: \mathrm{R}=$ phenyl; $\mathbf{d}$ : $\mathrm{R}=$ =ethynyl

133a,b

Scheme 32. Synthesis of Phenyldifluoromethylphosphonic Acid Derivertives
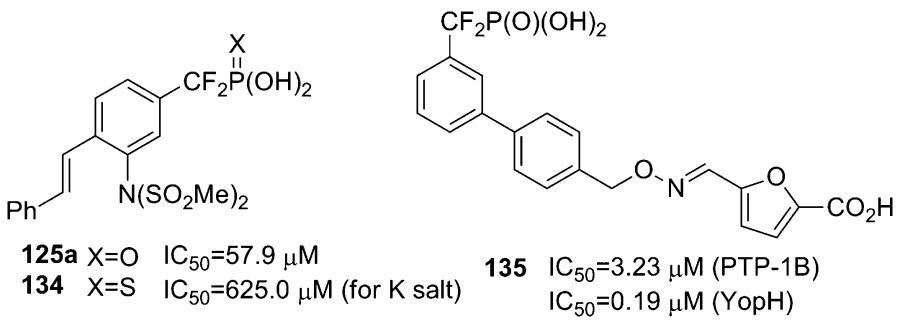

Fig. 13. PTP Inhibitors Based on Phenyldifluoromethyphosphonic Acids

スルホンアミド基は PTP-1B の活性中心付近の親 水性部分と効果的に相互作用したと推察される.

なお，安定な阻害活性を示した 125a のホスホノ チオ酸アナログ 134 の PTP-1B 阻害活性は $\mathrm{IC}_{50}=$ $625.0 \mu \mathrm{M}$ を示した. ${ }^{117)}$ すなわち，ホスホノチ才酸 に修飾すると活性が低下することが明らかとなつた (Fig. 13).

フェニルジフルオロメチルホスホン酸を基本構造 とする PTP 阻害剤の創製研究において, 最近で は，さらに活性の高い誘導体も報告されるように なった. Burkeらはフェニルジフルオロメチルホス ホン酸のメタ位フェニル基からオキシムエーテルリ
ンカーでフラン-2-カルボン酸を連結した誘導体 135 が強いPTP 阻害活性を示すことを報告している (Fig. 13).127) 135 の合成において, DFMPA 基の導 入には筆者らのカップリング反応が利用されている.

7-3-2. PTP 阻害剤の利用安定で活性の高い 125aについて，さらにセリン/スレオニンホスファ ターゼ PP 2A，膜貫通受容体 PTP である LAR に 対する阻害活性を評価したところ, $\left.{ }^{126}\right)$ 125a はセリ ン/スレオニンホスファターゼ PP $2 \mathrm{~A}$ には全く阻害 活性を示さなかつた。 LARにもほとんど阻害活性 を示さなかった。119 は PP 2A にも PTP-1B と同 程度の阻害活性を示すことが報告されており, 123) 
Table 5. Enzyme Selectivity and $K_{\mathrm{i}}$ value of $\mathbf{1 2 5 a}$

\begin{tabular}{ccc}
\hline \hline PTP-1B & PP2A & LAR \\
\hline $\mathrm{IC}_{50}=57.9 \mu \mathrm{M}$ & $\mathrm{IC}_{50}>1000 \mu \mathrm{M}$ & $\mathrm{IC}_{50}=414.9 \mu \mathrm{M}$ \\
$K_{\mathrm{i}}=176 \mu \mathrm{M}$ & $\mathrm{ND}^{\mathrm{a}}$ & $\mathrm{ND}^{\mathrm{a}}$ \\
mix-type inhibition & $\mathrm{ND}^{\mathrm{a}}$ & $\mathrm{ND}^{\mathrm{a}}$ \\
\hline
\end{tabular}

${ }^{a}$ Not determined.

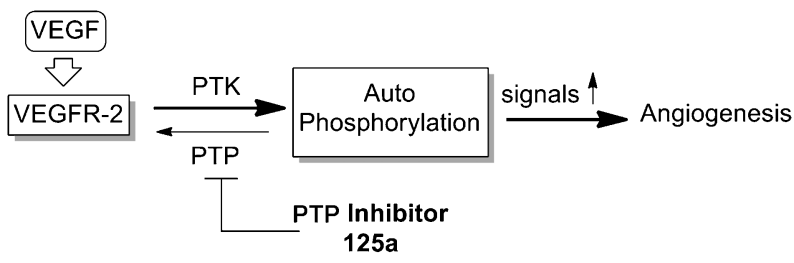

Fig. 14. Amplification of the Angiogenesis Signals by the PTP Inhibitor in VEGF-mediated Signal Transduction

125a が PTP-1B を選択的に阻害する化合物である ことが明らかとなった（Table 5).

酵素選択性の高い PTP 阻害剂 125a を見い出す ことができたので，125a を分子プローブとして用 いて，福岡大学生化学教室占野廣司教授及び添田秦 司教授との共同研究として，培養ヒ卜臍帯静脈内皮 細胞 (HUVEC) の細胞内情報伝達機構に与える効 果を検討した. ${ }^{128)}$

血管内皮細胞増殖因子（VEGF）が HUVEC の 血管新生受容体（VEGFR-2）に結合すると, VEGFR-2 に内在する PTK が活性化し，VEGFR-2 のリン酸化を経て血管新生のシグナルが生じること が知られている (Fig. 14)。血管新生のシグナル強 度は，PTK による VEGFR-2 のリン酸化と PTP に よる脱リン酸化の拮抗バランスで調節されていると 考えられた。PTPを阻害すると，相対的に VEGFR-2 のリン酸化が促進され，血管新生のシグ ナルが増幅されると推定した。

そこで，125a を HUVEC に作用させたところ， HUVEC 内の PTP 活性の阻害に伴って，PTK が相 対的に活性化され，VEGFによる血管新生シグナ ルの増幅が起こり，HUVEC の管腔形成，増殖及び

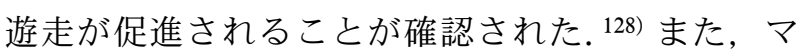
ウスの背部皮下におけるマトリゲル誘起による血管 新生は， 125a の共存下で促進されることが，機能 形態学的にも観測されることが明らかとなった. ${ }^{128)}$

7-4. スフィンゴミェリナーゼ（SMase）阻害剤 の創製前述した PTP 阻害剂に関する共同研究
の打ち合わせ会議で，セラミドを介する情報伝達系 を明らかとする分子プローブも同様の手法で作るこ とができないかとの提案があった．特に，共同研究 者の一人の添田教授は，長年，セラミドに関する生 化学研究を展開していて, 分子プローブの必要性を 感じているとのことであった，そこで，セラミドに 関して文献調査をしたところ，セラミドは，細胞内 の情報伝達物質 (セカンドメッセンジャー) として， 細胞のアポトーシス誘導, 細胞増殖抑制, ストレス 応答，炎症反応，脂質代謝，遺伝子転写などに関与 しているが，それらの生物応答のメカニズムなどに ついては，不明な点が多く，それらを解明するため の分子プローブは有用であることが分かった. ${ }^{129)}$

セラミドは, 細胞内で様々な合成系・代謝系経路 で産生されているが，その 1 つに，細胞膜の主要な 構成成分であるスフィンゴミエリン（SM）から酵 素スフィンゴミエリナーゼ（SMase）によって加水 分解を受けて生成される経路が知られていた（Fig. 15)。この経路は 1 工程でセラミドを生成すること から，外的因子によって素早く細胞応答を引き起こ す経路として重要と考えられていた。したがって,

SMase 阻害剂はセラミドを介する細胞内情報伝達 機構の解明のための最も有用な分子プローブの 1 つ となると期待されていた.

当時, SMase 阻害剤は, 天然物のスクリーニン グによる手法で見い出されており，代表的な化合物 として scyphostatin が知られていた (Fig. 16)。130,131) scyphostatin はラット脳由来中性 SMase に対して強 力かつ選択的な阻害作用 $\left(\mathrm{IC}_{50}=1.0 \mu \mathrm{M}\right)$ を示すこ とが明らかにされていた。しかしながら。 scyphostatin は, 構造が複雑で全合成も確立されて いなかったので，分子プローブとして利用すること は困難であった。

7-4-1. SMase 阻害剂の探索筆者は, より単 純な構造で，比較的簡単に合成可能な SMase 阻害 剂が分子プローブとして有用と考えた。当時, SMase の活性部位のアミノ酸配列などの構造情報 は知られていなかった。 そこで，SMase の基質構 造（SM）に着目して，その化学修飾により SMase 阻害剤を見い出すこととした。

化学修飾に当たっては，以下の点に留意した。す なわち，Katsumura らは，SMのアルケニル部（A） を飽和させた短鎖アナログ 136 やアミノアルコール 


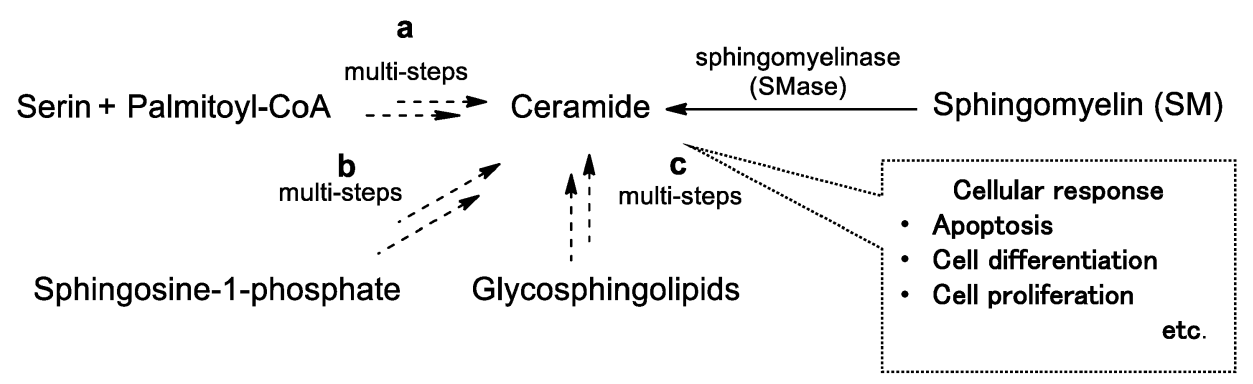

Fig. 15. Metabolic and de Novo Pathways for Formation of Ceramide in Cells

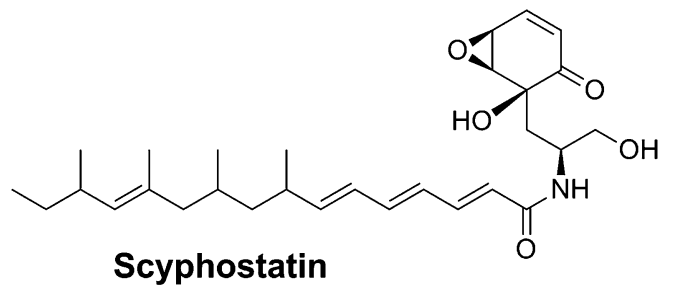

from discomycete, Trichopeziza mollissima

$\mathrm{IC}_{50}=1.0 \mu \mathrm{M}$ (for neutral SMase)

Fig. 16. A Neutral SMase Inhibitor Isolated from Natural Sources

部分（B）の立体配置をトレオ型に変換したアナロ グ 137 などを合成し，それらの SMase に対する親 和性を評価していた（Fig. 17）。132-134）この報告によ ると，E-配置の二重結合を含む長鎖は，SMase と の親和性に影響を及ぼさないが，アミノアルコール 部分のエリスロ型立体配置は，親和性に重要な影響 を及ぼすことが明らかとなっていた。しかしなが ら，コリン部分については，その必要性の有無は報 告されていなかった.

そこで，筆者は，アミノアルコール部の立体配置 と窒素上の置換基は天然型 SM のそれを保持し, リン酸ジエステル部（C）と長鎖アルケニル部（A） を，安定性を考慮してジフルオロメチレンホスホニ ル基とフェニル基でそれぞれ置換した類縁体 138 を 当初の標的化合物として設定し，関連化合物の合成 と SMase 阻害活性評価を検討した（Fig. 17）. 135,136)

標的化合物 138 は, 市販の $(1 S, 2 S)$-2-amino-1phenyl-1,3-propanediol（139）から容易に得られる アルデヒド 140 に $\operatorname{LiCF}_{2} \mathrm{P}(\mathrm{O})(\mathrm{OEt})_{2}$ を付加後, 立 体選択的に得られたアルコール 141 の脱オキシ化反 応を経て合成した。 また，アルコール141 から， $\alpha$-ヒドロキシ類縁体 143 も合成した。ささらに，139 のエナンチオマーも市販されていたので, 138 と
143 のエナンチオマー（ent-138 及び ent-143） につ いても，あわせて合成した（Scheme 33）.

同様の合成経路で，アミノアルコールの相対配置 をトレオ型に変更した誘導体 144 も合成可能であつ たが，144 は，速い $\mathrm{N} \rightarrow \mathrm{O}$ アシル転位が起こり，生 物活性評価を行うことはできなかった（Scheme 34).136) なお， ent-138については，ホスホノチ才酸 エステル142 から誘導したケトン $146(\mathrm{R}=\mathrm{Ph})$ の 立体選択的な還元を利用する合成経路でも合成可能 であった (Scheme 35). ${ }^{137)}$

以上に合成した SM 類縁体 $\mathbf{1 3 8}, \alpha$-ヒドロキシ類 縁体 143 及びそれらのエナンチオマー（ent-138, ent-143）について, ウシ脳ミクロソームから単離 された $\mathrm{Mg}^{2+}$ に依存性の高い中性 SMase (N-SMase), 微生物 (Bacillus cereus) から単離さ れた中性 SMase（N-SMase）及びウシ脳リソソー ムから単離された酸性 SMase（A-SMase）に対す る阻害活性を評価した (Table 6). ${ }^{135,136)}$

これらの化合物は, 微生物由来 (Bacillus cereus) の N-SMase に対しては，阻害活性を示さなかっ た。しかし, ウシ脳ミクロソームから単離された $\mathrm{Mg}^{2+}$ に依存性の高い $\mathrm{N}-\mathrm{S} M a \mathrm{se}$ に対して阻害活性 を示した。興味深いことに，天然 SM の立体配置 と同じ立体配置を有する SM 類縁体 138 及び 143 よりも，それらのエナンチオマー ent-138 及び ent-143 の方が約 4-60 倍高い阻害活性を示した.

ent-138 は，このシリーズのなかで，N-SMase に対 して最も高い阻害活性（ $\mathrm{IC}_{50}=3.3 \mu \mathrm{M} ）$ を示し，前 述した天然物 scyphostatin とほぼ同等の阻害活性を 示すことが明らかとなつた。 また， ent-138 は， 3.3 $\mu \mathrm{M}$ の濃度でウシ脳リソソームから単離された ASMase を $48 \%$ 阻害することも明らかとなつた。さ らに, Lineweaver-Burk plots の解析から, ent-138 はウシ脳ミクロソームから得られた N-SMase を非 


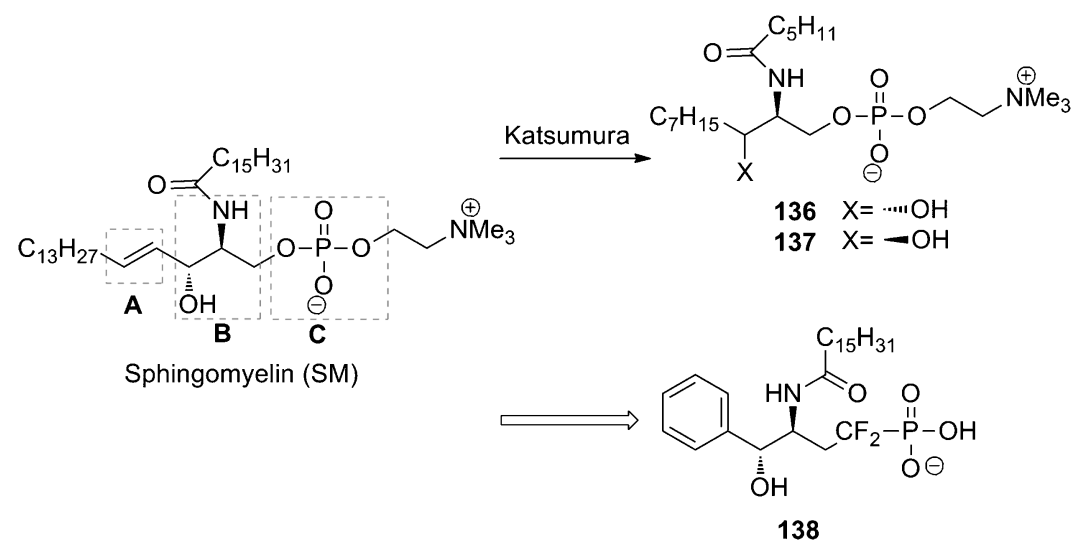

Fig. 17. Chemical Modification of Sphingomyelin
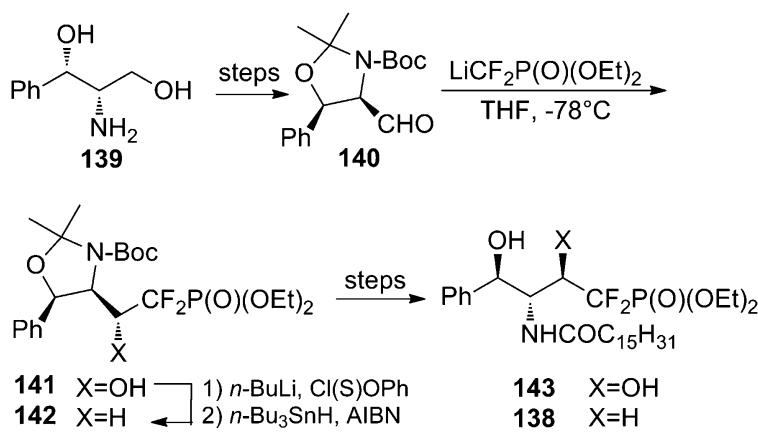

Scheme 33. Synthesis of the Target Compounds<smiles>CCOC(=O)OCCC1C([PH+]C)OC(C)(C)N1C(=O)OCC</smiles>

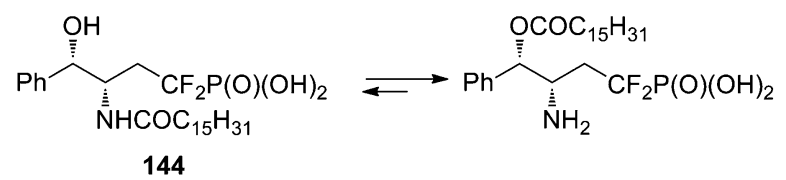

Scheme 34. Synthesis of the threo-Isomer and the $\mathrm{N} \rightarrow \mathrm{O}$ Acyl Rearrangement

競合阻害することが明らかとなつた。

以上の筆者らの報告とほぼ同時期に，Katsumura らは, SM のエステル酸素を他の原子団で置換した 短鎖類縁体 147 の合成に成功し，その阻害活性を報 告した（Fig. 18）. 133,134) この報告では，これらの短 鎖類縁体は微生物由来（Bacillus cereus）の NSMase を比較的低濃度で競合阻害することが明ら かとされた。筆者らの阻害剤 ent-138 は，Katsumura らの阻害剤 147 とは，阻害形式が異なってい た，ent-138 の結合部位の特定など，更なる阻害メ カニズムの解明と ent-138 の構造最適化も必要で あった. しかし, これらの研究展開は, 当時の狂牛 病の流行により研究材料のウシ脳ミクロソーム及び リソソーム由来の SMase が入手困難となり，断念 しなければならなかった。誠に残念であった。

7-4-2. SMase 阻害剤（SMA-7）の利用しか しながら，SMase 阻害剤 ent-138 は，N-SMase に対 して十分な阻害活性を有することから SMA-7 と命 名し, 福岡大学薬学部の添田教授との共同研究とし て，以下のセラミド情報系の機構解明の分子プロー ブとして活用することができた. ${ }^{138-142)}$

1）がん細胞における A-SMase の役割解明

2）脳虚血による神経細胞死と SMase 活性の関 連解明

3）ヒト末梢血単核細胞 (HPBMC) のリポポリ サッカロイド (LPS) 刺激による炎症性サイト カイの放出阻止効果

4）炎症性腸疾患の改善効果

5） SMase 活性の阻害による脂肪細胞のインス リン抵抗性の改善効果

以上の共同研究から, 以下の結果が得られた。す なわち，SMA-7 は腫瘍壊死因子（TNF- $\alpha ）$ で誘起 される PC-12 ニューロンの細胞死を低濃度（0.1 $\mu \mathrm{M} ）$ で阻止することが明らかとなった。この神経 細胞死の抑制効果は, SMA-7 が脳神経細胞膜に存 在する $\mathrm{Mg}^{2+}$ 依存性中性 SMase を阻害し, 脂質セ カンドメッセンジャー (セラミド) のアポトーシス シグナルが遮断されることにより発現することが明 らかとなった。ささらに，マウス中大脳動脈閉塞モデ 

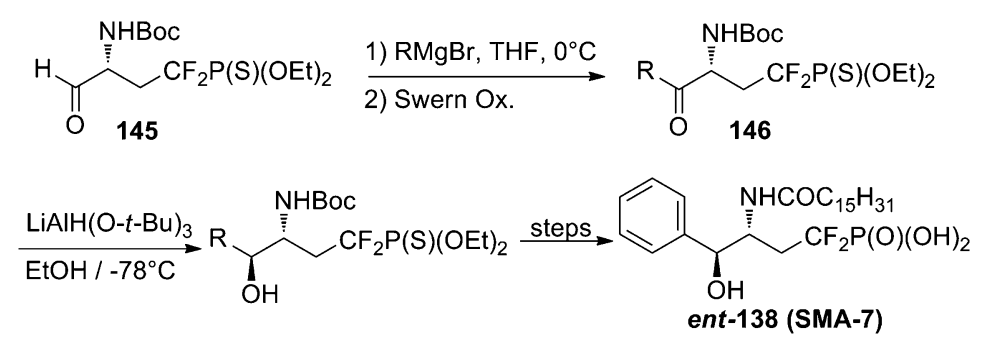

Scheme 35. Alternative Synthesis of ent-138 through a Highly Divergent Method

Table 6. $\mathrm{IC}_{50}$ and $K_{\mathrm{i}}$ Values of SM Analogues against NSMase from Bovine Brain Microsomes

\begin{tabular}{ccc}
\hline \hline Compd & $\mathrm{IC}_{50}(\mu \mathrm{M})$ & $K_{\mathrm{i}}(\mu \mathrm{M})$ \\
\hline $\mathbf{1 4 3}$ & 377 & 253 \\
$\mathbf{1 3 8}$ & 181 & $\mathrm{ND}$ \\
ent $\mathbf{- 1 4 3}$ & 99 & $\mathrm{ND}$ \\
ent-138 & 3.3 & 1.6 \\
\hline
\end{tabular}

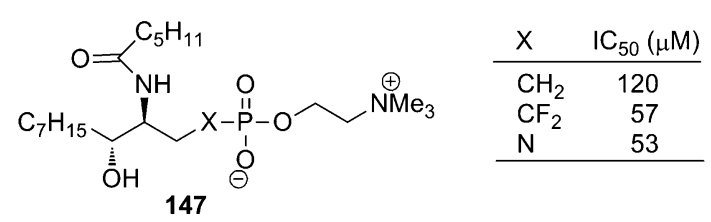

Fig. 18. Inhibitory Activities of SM Analogues Having a Choline Moiety

ルにおいて，SMA-7 は投与群の脳の梗塞領域を有 意に減少した。その減少効果は SMase 阻害活性に よく相関することが明らかとなった，以上の結果か ら, SMase 阻害剂がサイトカインや虚血に起因す る細胞ストレスシグナルの遮断に有効である可能性 が示唆された. ${ }^{139)}$

HPBMC の LPC 刺激により放出される炎症性サ イトカインは, SMA-7 の共存下で有意に減少し た。 また, マウス炎症性腸疾患モデルにおいて,

SMA-7 の投与群は，杯細胞の減少と粘膜下層への 細胞浸潤の抑制などがみられた。以上の結果から
N-SMase を特異的に阻害することにより，炎症性 腸疾患特有の病態が改善される可能性が示唆され た. ${ }^{140-142)}$

なお，SMA-7 関連化合物のうち， $\alpha$-ヒドロキシ 類縁体 143 はがん細胞における de novo セラミド 合成ルートの活性化とジヒドロセラミド合成酵素の 役割を明らかとするための有用な分子プローブとな ることも判明した. ${ }^{138)}$

7-5. プリンヌクレオシドホスホリラーゼ (PNP) 阻害剂の創製 リン酸は, 生体内に普遍的に分布 している分子であり, 多くの生体内反応に係わって いる，例えば，核酸のサルベージ経路において，プ リンヌクレオシドは, PNP の触媒作用により加リ ン酸分解をうけ, リボース-1ーリン酸とプリン塩基 に分解される (Fig. 19). 143,144)

生体内では，この反応は，DNA や RNAの合成 に必要なプリン塩基を供給する役割を担っている.

したがって, PNP を阻害すると, 細胞内でプリン 塩基の供給が停止し，DNA や RNA の合成が抑制 される. ${ }^{143)}$

PNP は T 細胞に高発現していることが知られて おり, PNP 阻害剤は $\mathrm{T}$ 細胞の異常増殖により引き 起こされる $\mathrm{T}$ 細胞白血病, $\mathrm{T}$ 細胞リンパ腫, 成人 $\mathrm{T}$ 細胞白血病（ATL）などの治療薬として有用で あろうと期待されている. ${ }^{143)}$ PNP の活性部位に は，プリン塩基を認識する Purine binding site, リ

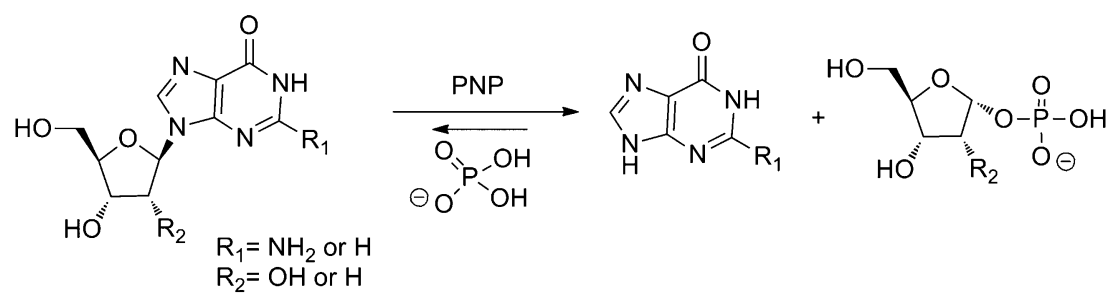

Fig. 19. Phosphorolysis of Purine Nucleosides Catalyzed by PNP 


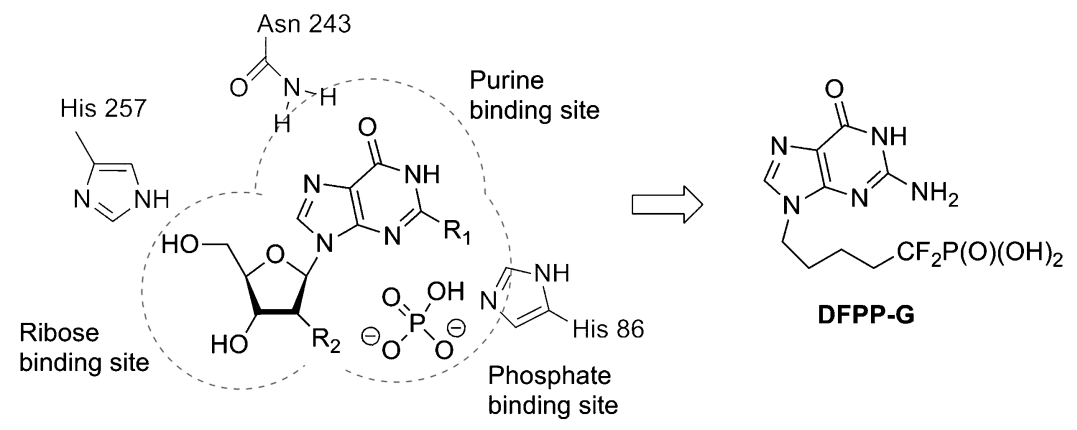

Fig. 20. Binding Sites and Multi-substrate Analogue Inhibitors for PNP

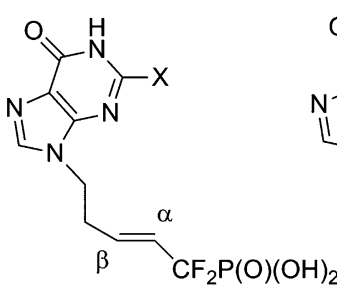

$E-148 a, b$

a: $\mathrm{X}=\mathrm{NH}_{2}, \mathbf{b}: \mathrm{X}=\mathrm{H}$

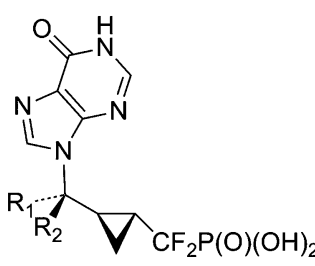

$151 \mathrm{R}_{1}=\mathrm{Me}, \mathrm{R}_{2}=\mathrm{H}$

$152 \mathrm{R}_{1}=\mathrm{H}, \mathrm{R}_{2}=\mathrm{Me}$

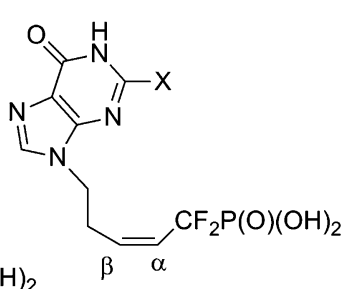

Z-148a,b

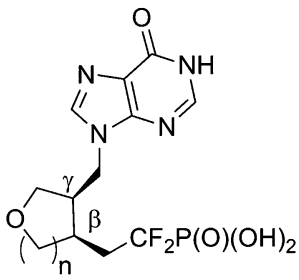

cis $-153 \mathrm{n}=1$

cis-154 $\mathrm{n}=2$

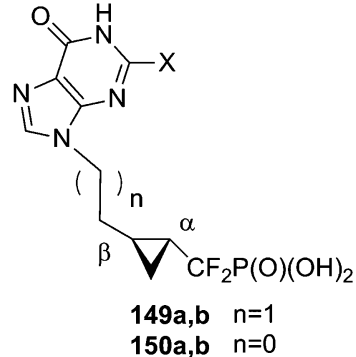

$150 a, b \quad n=0$<smiles>O=c1[nH]cnc2c1ncn2C[C@H]1COC[C@@H]1CC(F)(F)F</smiles>

trans $-153 \mathrm{n}=1$ trans-154 $\mathrm{n}=2$

Fig. 21. DFPP-G Analogues Having Modified Linkers and Nucleobases

ボース部分を認識する Ribose binding site, リン酸 を認識する Phosphate binding site が存在すること が知られている (Fig. 20). ${ }^{145)}$ PNPは，これらの binding site にプリンヌクレオシドと無機リン酸の 二基質を取り込み，Fig. 19 に示した加リン酸分解 反応を触媒している.

PNP 阻害剤は，1）基質の 1 つであるプリンヌク レオシドを化学修飾する方法143,145-147) と，2）2つ の基質（プリンヌクレオシドと無機リン酸）に注目 し，そのフラグメントをリンカーにより結合する方 法143,148,149) で見い出されてきた。 2) の方法は，標 的タンパク質に対して親和性を有する 2 つのラグ メントをリンカーで連結し，もとのフラグメントよ りも親和性の高い分子を見い出す方法，いわゆる fragment-based drug design (FBDD) を基本にして いる. 150) 2) の方法による PNP 阻害剤の創製研究
において, Danzin らは, グアニンと無機リン酸の ミミック $\left[\mathrm{HCF}_{2} \mathrm{P}(\mathrm{O})(\mathrm{OH})_{2}\right]$ をメチレン 4 炭素で 連結した誘導体 DFPP-G に強い PNP 阻害活性を見

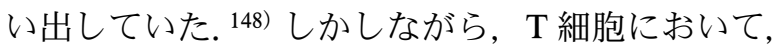
PNP は高発現していることから，PNP 阻害剤を医 薬として利用するためには，解離定数 $K_{\mathrm{d}}$ 值が 10 $\mathrm{nM}$ 以下で阻害活性を示す分子を見い出すことが求 められていた. ${ }^{143)}$ 筆者は, Danzin らの報告以降に DFPP-G の構造展開が十分に行われていないこと に着目し，DFPP-G の構造展開を基本として高活 性 PNP 阻害剤の創製を検討した。

7-5-1. リンカーの修飾ＤFPP-G は，二基質 複合型アナログとして，PNP の Purine binding site と Phosphate binding site に取り込まれて阻害活性 を示すことが，基質との競合阻害実験から推定され ていた. ${ }^{148)}$ DFPP-G の核酸塩基部とリン酸ミミッ 
Table 7. Comparison of Inhibition Constants of Synthesized Compounds for PNPs

\begin{tabular}{lrrrrr}
\hline \hline \multirow{2}{*}{ Compound } & \multicolumn{2}{c}{$\begin{array}{c}\text { PNP from } \\
\text { Cellulomonas sp. }\end{array}$} & & \multicolumn{2}{c}{$\begin{array}{c}\text { PNP from human } \\
\text { erythrocytes }\end{array}$} \\
\cline { 2 - 3 } \cline { 5 - 6 } & $\mathrm{IC}_{50}(\mathrm{nM})^{\mathrm{a}}$ & $K_{\mathrm{i}}(\mathrm{nM})^{\mathrm{a}}$ & & $\mathrm{IC}_{50}(\mathrm{nM})^{\mathrm{a}}$ & $K_{\mathrm{i}}(\mathrm{nM})^{\mathrm{a}}$ \\
\hline DFPP-G & 540 & 28.7 & & 380 & 53.7 \\
$(\boldsymbol{E})$-148a & 170 & 20.4 & & 400 & 30.7 \\
$(\boldsymbol{Z})$-148a & 200 & 29.1 & & 310 & 27.6 \\
$( \pm)$-149a & 390 & 28.2 & & 330 & 43.4 \\
$( \pm)$-150a & 291000 & 53200.0 & & 391000 & 39067.0 \\
$(\boldsymbol{E})$-148b & 280 & 11.4 & & 320 & 32.1 \\
$(\boldsymbol{Z})$-148b & 240 & 16.2 & & 360 & 32.1 \\
$( \pm)$-149b & 70 & 8.8 & & 340 & 17.3 \\
$( \pm)$-150b & 190 & 5.4 & & 380 & 23.4 \\
$\mathbf{1 5 1}$ & 70 & 20.4 & & ND & ND \\
$\mathbf{1 5 2}$ & 90 & 19.6 & & ND & ND \\
$( \pm)$-cis-153 & ND & ND & & 88 & ND \\
$( \pm)$-trans-153 & ND & ND & & 320 & ND \\
$( \pm)$-cis-154 & ND & ND & & 38 & 26.9 \\
$( \pm)$-trans-154 & ND & ND & & 106 & ND \\
\hline
\end{tabular}

a Determined in the presence of $0.1 \mathrm{~mm}$ inosine and $100 \mathrm{~mm} \mathrm{Pi}(\mathrm{pH} 7.5)$.

ク部分の空間的な配置は，PNP との親和性に大き な影響を及ぼすことが考えられた。そこで，筆者 は，リンカーの配座を制限した分子を合成し，それ らの PNP 阻害活性を評価した。 ${ }^{108-111,151) ~}$ 代表的な 分子の構造と PNP 阻害活性を，それぞれ，Fig. 21 及び Table 7 に示す。合成法の詳細は省略するが,

7-1. で述べた合成中間体が有効に利用された。

合成したヌクレオチドアナログは，イノシン (0.1 mM) 及び無機リン酸（100 mM）の共存下に, ヒト赤血球由来 PNP 並びに微生物（Cellulomonas sp.）由来 PNP に対する阻害活性を DFPP-G のそ

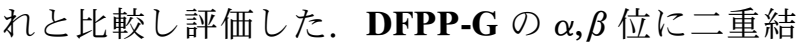
合を導入した配座固定類縁体（E-148a と $Z$-148a $)$ では，活性の大幅な変化は認められなかつた. ${ }^{110,111)}$ また， $\alpha, \beta$ 位に trans- 配置のシクロプロパン環を導 入して配座固定した類縁体 $[( \pm)$-149a) において も，活性の大幅な変化は認められなかった。しかし ながら，(土)-149a を 1 炭素減炭して $( \pm)-150 a に$ 構造展開すると, 活性は完全に消失した. ${ }^{111)}$

一方，以上の配座固定類縁体（E-148a, $Z-148 a$, （土）-149a，（土）-150a）の核酸塩基部をグアニンか らヒポキサンチンに変更した類縁体（E-148b，Z148b，（土）-149b，（土）-150b）では，活性が向上す る傾向が認められた。. ${ }^{111)}$ 特に活性の認められな
Table 8. Effects of Pi Concentration on Inhibition of DFPPG and ( \pm$)$-cis-154 for Human PNP

\begin{tabular}{lccccc}
\hline \hline \multirow{2}{*}{ Compound } & \multicolumn{2}{c}{$\mathrm{IC}_{50}(\mathrm{nM})^{\mathrm{a}}$} & & \multicolumn{2}{c}{$K_{\mathrm{i}}(\mathrm{nM})^{\mathrm{a}}$} \\
\cline { 2 - 3 } \cline { 5 - 6 } & $1 \mathrm{mM} \mathrm{PO}_{4}$ & $100 \mathrm{mM} \mathrm{PO}_{4}$ & & $1 \mathrm{mM} \mathrm{PO}_{4}$ & $100 \mathrm{mM} \mathrm{PO}_{4}$ \\
\hline DFPP-G & 32.5 & 380 & & 17.5 & 53.0 \\
$( \pm)$-cis-154 & 8.7 & 38 & & 3.5 & 26.9 \\
\hline
\end{tabular}

a Determined in the presence of inosine $(0.1 \mathrm{~mm})$ at $\mathrm{pH} 7.5$.

かった (土)-150a の核酸塩基部をヒポキサンチンに 変更して $( \pm)-\mathbf{1 5 0 b}$ に構造展開すると, PNP 阻害 活性が認められ，PNP との親和性が DFPP-Gより も 2-5 倍に高まることが明らかとなった。（土）150b の核酸塩基の $\alpha$ 位にメチル基を導入すると, 活性の低下が観測された。（士）-150b の両鏡像体の 合成も可能であったが，鏡像体による活性の違いは 認められなかつた. ${ }^{110)}$

$\beta, \gamma$ 位にテトラヒドロフラン環及びピラン環を縮 環した類縁体 $[( \pm)$-cis-153，（士)-trans-153，（士)cis-154，（土）-trans-154]は，これらのへテロ環が リンカーの配座固定と PNP の Ribose binding site との相互作用に寄与すると期待して設計された分子 である。これらの分子の活性は, trans 体よりも cis

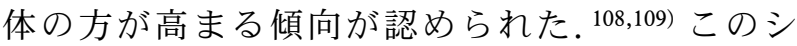
リーズのなかで最も高活性を示した（土）-cis-154 について，さらに詳細な解析を行った。すすなわち, ヒト細胞中のリン酸濃度は $1 \mathrm{mM}$ であることから, リン酸濃度を $1 \mathrm{mM}$ に変更して，ヒトPNP に対す る阻害活性を評価した（Table 8)。その結果，リン 酸濃度を $100 \mathrm{mM}$ から $1 \mathrm{mM}$ に低下すると，（土）cis-154 の $\mathrm{IC}_{50}$ 值と $K_{\mathrm{i}}$ 值は濃度依存的に低下するこ とが明らかとなった。これらの結果から，(土)cis-154 は，二基質複合型アナログとして Purine binding site と Phosphate binding site の両方に取り 込まれて阻害活性を示す分子であることが推定され た。また， $1 \mathrm{mM}$ のリン酸濃度で DFPP-G と $( \pm)$ cis-154 の阻害活性を比較すると，(土）-cis-154 は, DFPP-G の 4-5 倍の阻害活性を示すことが明らか となった.

\section{7-5-2. 核酸塩基部の修飾（共同研究での展開）}

前述したリンカーの修飾に関する結果が論文とし て掲載されて間もないころ, 北海道大学薬学部で核 酸化学の研鑽を積んだ正島貞雄助教が本教室の教育 研究教育に参加することとなり，PNP 阻害剤の開 


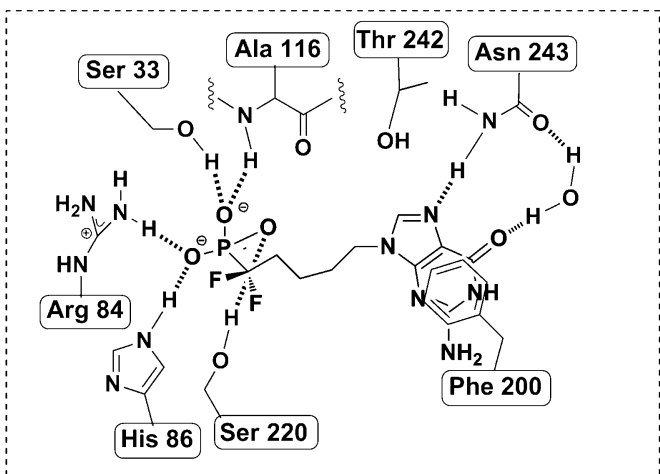

Fig. 22. Interactions of DFPP-G with Calf-spleen PNP in the Binary Complex

発を担当することとなった．また，ワルシャワ大学 物理学科の David Shugar 教授から一通の手紙と PNP に関する総説143)が送られてきた. Shugar 教授 は，世界的に著名な生物物理学者で，特に PNP の 触媒機構研究の大家だった.この手紙をきっかけと して, Shugar 教授の後継者である Bzowska 教授の グループとのPNP 阻害剤に関する共同研究を推進 することとなつた. ${ }^{152-163)}$

この共同研究では, 当初, ( \pm )-cis-154 の calf spleen PNP に対するより精密な阻害定数や解離定 数が明らかとされた。また，三量体として存在する calf spleen PNP に対して，(土)-cis-154 が結合する 分子数（ストイキオメトリー）などの解析が行われ た. ${ }^{155)}$ さらに, PNP 阻害剤の治療薬としての可能 性を探索したところ，リンカーにテトラヒドロフラ ン環を組み込んだ PNP 阻害剂（土）-cis-153 が自己 免疫疾患患者（橋本病）の $\mathrm{T}$ リンパ球の増殖阻止 に顕著な効果を示すことが明らかとなった. ${ }^{157)}$

その後, DFPP-G と calf spleen PNP の共結晶の $\mathrm{X}$ 線結晶解析に成功し, 詳細な結合様式を明らか とすることができた (Fig. 22). ${ }^{156)}$

この X 線結晶解析より, DFPP-G のジフルオロ メチレンホスホン酸ユニットは, Phosphate binding site において Ser220, Ser33, Ala116 や塩基性ア ミノ酸残基 His86, Arg84 との水素結合を形成して いた。 すなわち，期待通りジフルオロメチレンホス ホン酸ユニットはリン酸ミミックとして機能し，こ の結合部位にリン酸と同様に認識されていることが 確認された. Purine binding siteにおいて，グアニ ンユニットは Asn243 と水を介した水素結合及び Phe200 とのスタッキングで相互作用していた.
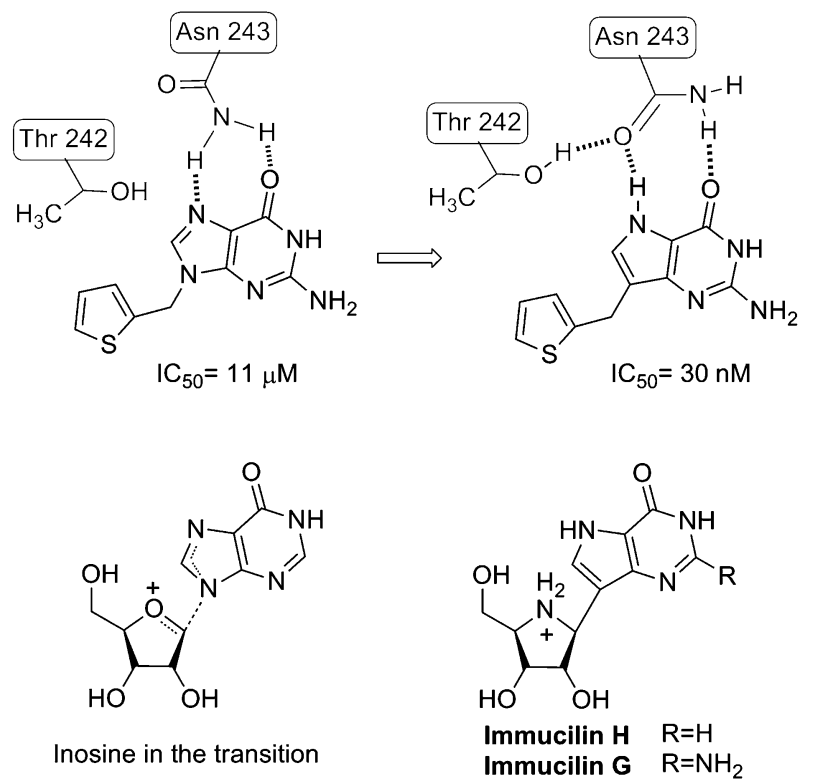

Fig. 23. 9-Deazaguanine Derivertives for PNP Inhibitors

以上の解析結果から, Purine binding site との水 素結合のネットワークにおいて，水を介さない水素 結合が形成されるように，グアニン塩基部を化学修 飾すれば，PNP との親和性が高まることが予想さ れた。核酸塩基と Purine binding site との水素結合 に関しては，Montgomery らにより詳細な検討がさ れており,グアニンを非天然型 9-デアザグアニン に置き換えると，水素結合のネットワークが変化し， PNP 阻害活性が 300 倍程度に高まることが報告さ れていた (Fig. 23). 143,145,146)

また，9-デアザグアニンあるいは 9-デアザヒポキ サンチンをアザ糖に結合した核酸アナログ（Immucillin G 及び Immucillin H）は，アザ糖の窒素 原子がイノシンの加リン酸分解の遷移状態（電荷状 態）を模倣できる遷移状態アナログで，ピコモル オーダーの濃度で PNP との親和性を示すことが知 られており, 臨床開発候補として研究が進められて いた (Fig. 23). ${ }^{147)}$

以上の知見を踏まえて，筆者は，DFPP-G のグ アニン塩基をデアザグアニンに置換した類縁体 （DFPP-DG）及びその炭素鎖長を減炭あるいは増 炭した類縁体（nor-DFPP-DG, homo-DFPP-DG 及 び 6C-DFPP-DG）を新たにデザイン・合成した (Fig. 24). 152-154) また, 水溶性の向上と加リン酸分 解の遷移状態で生成するオキソカルベニウムイオン のミミックを目的として， DFPP-G のリンカーの 

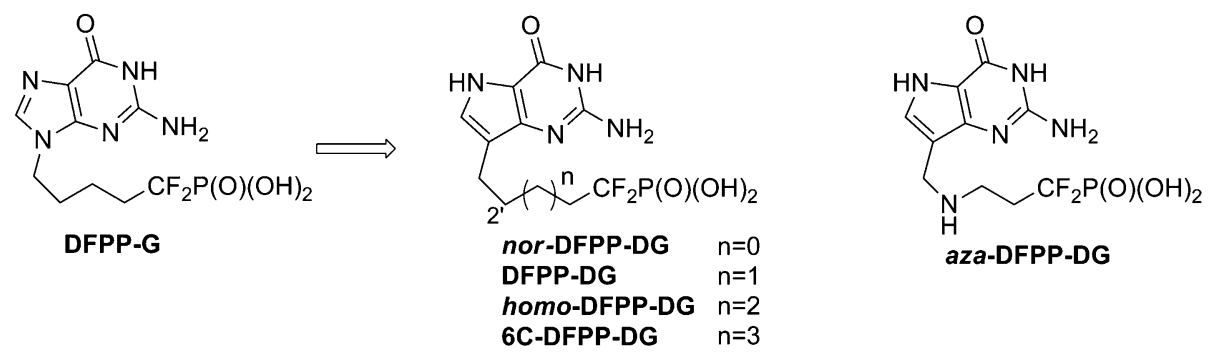

Fig. 24. Modifications of DFPP-G with Transition-state Features

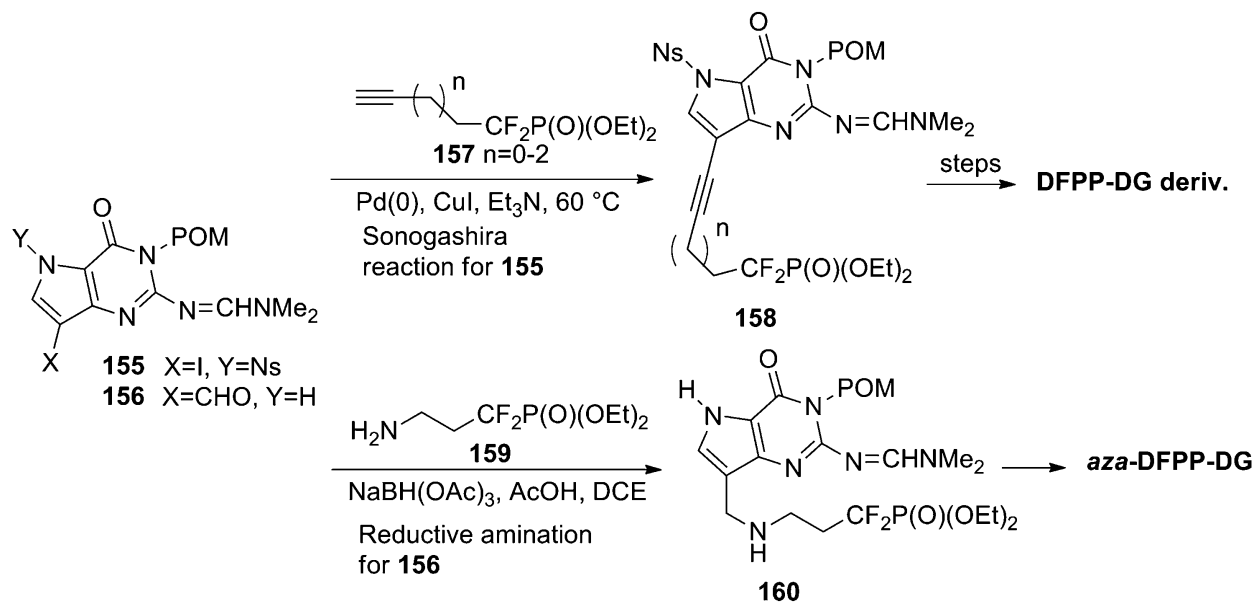

Scheme 36. Synthesis of DFPP-DG Deriv. and $a z a$-DFPP-DG

2'位に窒素原子を組み入れた類縁体（aza-DFPPDG）をデザイン・合成した（Fig. 24）。163）合成法 の詳細は省略するが，DFPP-DG 誘導体は，9-ヨー ドデアザグアニン誘導体 155 と $\omega$ - アルキニルホス ホナート 157 の Sonogashira 反応により得られた中 間体 158 から容易に合成できた（Scheme 36）。ま た， $a z a$-DFPP-DG 誘導体は，9-ホルミルデアザグ アニン誘導体 156 の還元的なアミノ化反応により得 られる中間体 160 から容易に得られた (Scheme 36).

以上に得られた DFPP-DG deriv. の阻害活性につ いては, calf spleen 由来 PNP（caPNP）及び human erythrocyte 由来 PNP (huPNP) に対する $\mathrm{IC}_{50}$ 值及びみかけの阻害定数（ $\left.K_{\mathrm{i}}^{\mathrm{app}}\right)$ で初期の評価を 行った (Table 9). 152,153,162)

以上の評価において，DFPP-DG とDFPP-G を $K_{\mathrm{i}}^{\mathrm{app}}$ で比較すると，わずかに DFPP-DG の活性が 高いと言えるが， $\mathrm{IC}_{50}$ 值の比較では，ほぼ同等の 活性を示した．また，DFPP-DG の炭素鎖を 1 炭素 減炭すると活性の大幅な減少が認められた。リン カーの炭素を 1 炭素増炭すると活性が高まる傾向が
Table 9. Inhibitory Properties of DFPP-DG Deriv. against huPNP and caPNP

\begin{tabular}{lccccc}
\hline \hline & \multicolumn{3}{c}{$\begin{array}{c}\text { Human erythrocyte } \\
\text { PNP }\end{array}$} & & \multicolumn{2}{c}{ Calf spleen PNP } \\
\cline { 2 - 3 } \cline { 5 - 6 } Compd. & $\begin{array}{c}\mathrm{IC}_{50} \\
{[\mathrm{nM}]^{\mathrm{a}}}\end{array}$ & $\begin{array}{c}K_{\mathrm{i}}^{\mathrm{app}} \\
{[\mathrm{nM}]^{\mathrm{a}}}\end{array}$ & & $\begin{array}{c}\mathrm{IC}_{50} \\
{[\mathrm{nM}]^{\mathrm{a}}}\end{array}$ & $\begin{array}{c}K_{\mathrm{i}}^{\mathrm{app}} \\
{[\mathrm{nM}]^{\mathrm{a}}}\end{array}$ \\
\hline DFPP-G & 20.2 & $10.8 \pm 0.7$ & & 18.7 & $6.9 \pm 0.7$ \\
nor-DFPP-DG & 173 & - & & - & - \\
DFPP-DG & 20.4 & $8.1 \pm 0.6$ & & 10.2 & $4.4 \pm 0.6$ \\
homo-DFPP-DG & 9.5 & $5.3 \pm 0.4$ & & - & $5.7 \pm 0.6$ \\
6C-DFPP-DG & - & $13 \pm 1$ & & - & $21 \pm 2$ \\
\hline
\end{tabular}

a Obtained in the presence of $1 \mathrm{~mm}$ phosphate.

認められたが，2 炭素増炭すると活性の低下が認め られた。しかしながら， Montgomery の報告のよう に, ${ }^{143-145)} \mathrm{IC}_{50}$ 值が劇的に低下することは認められ なかった.

そこで，次に，核酸塩基を 9-デアザグアニンに 置換した効果を検証するために, DFPP-DG/ caPNP 複合体の X 線結晶構造から，相互作用のパ ターンを解析した（Fig. 25）. 159）その結果，DFPPDG は，二基質複合型アナログとして Purine bind- 


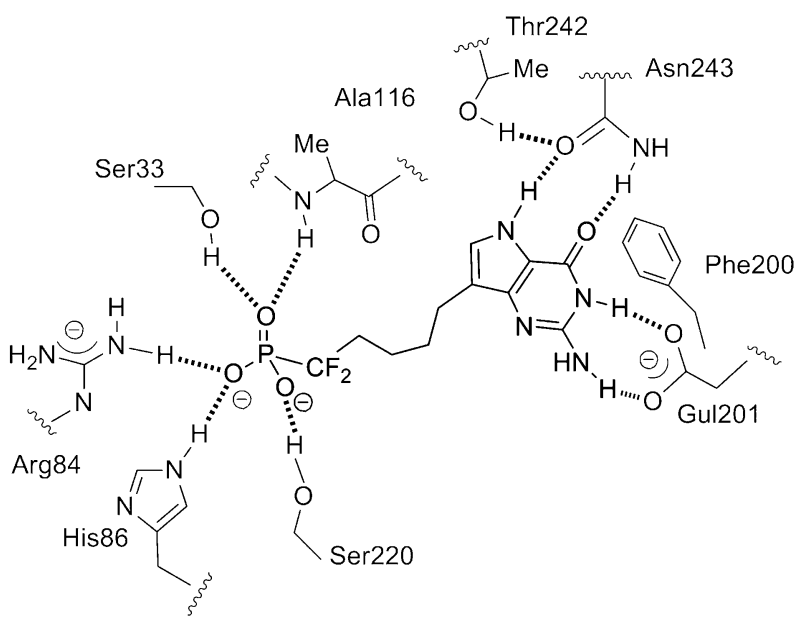

Fig. 25. Interactions of DFPP-DG with Calf-spleen PNP in the Binary Complex

$$
[\mathrm{E}]+[\mathrm{I}] \underset{k_{\mathrm{off} 1}=0.021 \mathrm{~s}^{-1}}{\stackrel{k_{\mathrm{on} 1}=17.6 \times 10^{5} \mathrm{M}^{-1} \mathrm{~s}^{-1}}{\rightleftarrows}}[\mathrm{EI}] \underset{\begin{array}{c}
k_{\text {off } 2}=0.024 \mathrm{~s}^{-1} \\
\text { conformation changes }
\end{array}}{\stackrel{k_{\mathrm{on} 2}=1.22 \mathrm{~s}^{-1}}{\rightleftarrows}}[\mathrm{EI}]^{*}
$$

Fig. 26. Rate Constants for a Two-step Binding of DFPP-DG to Calf-spleen PNP

ing site と Phosphate binding site の両方に取り込ま れて阻害活性を示す分子であることが確認された。 また, Purine binding site の Asn243 との水素結合 において，水分子は存在しておらず，期待通り， 9-デアザグアニン部が直接相互作用していることが 明らかとなった。

X 線結晶解析で DFPP-DG の結合様式が明らか となったので, 次に, DFPP-DGについて, 阻害速 度に関する速度論的解析を行つた. ${ }^{160)}$ その結果,

DFPP-DG による caPNP の阻害は, EI 錯体のコン フォメーションを伴う 2 段階の連続反応で進行して いることが明らかとなった（Fig. 26）。また，それ ぞれの素反応の速度定数の解析から, DFPP-DG は, slow-binding tight inhibitor として, PNP を阻害す ることが明らかとされた.

そこで, Fig. 26 の阻害反応が平衡に達したとき の阻害定数 $\left(K_{\mathrm{i}}^{\mathrm{eq}}\right)$ で, DFPP-DG 類縁体と Immucillin H $の$ caPNP に対する阻害能を評価し た. ${ }^{160)}$ Table 10 に, $K_{\mathrm{i}}^{\mathrm{eq}}$ 值と解離定数值 $\left(K_{\mathrm{d}}\right)$ を示 す。この解析により, DFPP-DG $の K_{\mathrm{i}}^{\mathrm{eq}}$ 値は $85 \pm$ $13 \mathrm{pM}$ と算出され, Immucillin $\mathbf{H}$ のそれ $\left(K_{\mathrm{i}}^{\mathrm{eq}}=23\right.$ $\pm 5 \mathrm{pM})$ と同等の值を示した。 また, DFPP-G と
Table 10. Inhibitory Properties of Immucilline $\mathbf{H}$ and DFPPDG Derivertives at the Inhibition Equilibrium

\begin{tabular}{lcc}
\hline \hline & $K_{\mathrm{i}}^{\text {eq }}[\mathrm{nM}]$ & $K_{\mathrm{d}}[\mathrm{nM}]$ \\
\hline Immucillin H & $0.023 \pm 0.005$ & $2.3 \pm 0.5 \times 10^{-11}$ \\
DFPP-DG & $0.085 \pm 0.013$ & $1.0 \pm 0.5 \times 10^{-10}$ \\
DFPP-G & $0.72 \pm 0.13$ & $4.6 \pm 1.1 \times 10^{-10}$ \\
$a z a$-DFPP-DG & $6.8 \pm 0.4$ & $3.6 \pm 0.5 \times 10^{-9}$ \\
\hline
\end{tabular}

$a z a$-DFPP-DG $の K_{\mathrm{i}}^{\mathrm{eq}}$ 值は，それぞれ， $0.72 \pm 0.13$ $\mathrm{nM}$ 及び $6.8 \pm 0.4 \mathrm{nM}$ を示した。 すなわち，DFPPGの核酸塩基部を 9-デアザグアニンに置き換える と，阻害活性が 10 倍程度に向上することが明らか となった。しかし，リンカーへの窒素原子の導入と 核酸塩基部の 9-デアザグアニンへの変更は予想に 反して，阻害活性を低下させることが明らかとなつ た.

各種 cell line を対象とする細胞毒性試験の結果か ら, DFPP-DG は，橋本病やグレーブス病の自己免

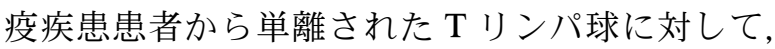
顕著な増殖阻止効果を示すことが明らかとなっ た. 160) しかし，DFPP-DG の細胞膜透過性は低く， 増殖阻止濃度は中程度で留まった。DFPP-DG の細 胞膜透過性の改善は今後の課題として残されたが,

DFPP-DG 及び関連類縁体は，Immucillin H の PNP 阻害メカニズム解明のための分子プローブと して有効に利用された. ${ }^{155-163)}$

\section{8. トロンビン選択的非拮抗阻害剤の創製}

2011 年 4 月に, 分子細胞生物学研究所（橋本祐 一先生の研究室）から, 当教室の准教授として青山 洋史先生が教育研究に参加することとなった．青山 准教授は, タンパク質の行動制御に基づく創薬手法 において，小分子によるプロテアソームなどのタン パク質の行動制御に成功していた。 また，サリドマ イドの構造展開から，トリプシン様セリンプロテ アーゼのうち，アトピー性皮膚炎などのアレルギー 疾患のメディエーターの 1 つであるトリプターゼ に，選択的な阻害活性（ $\left.K_{\mathrm{i}}=44 \mathrm{nM}\right)$ を示すフタル 酸イミド誘導体 161 を見い出していた（Fig. 27).164) しかしながら，フタル酸イミド誘導体 161 の活性と酵素選択性は十分とは言えず，実用化に耐 え得る段階までには至っていなかった.

そこで，筆者らは以上の先行研究を踏まえて，フ タル酸イミド誘導体 161 の更なる構造展開を検討し 


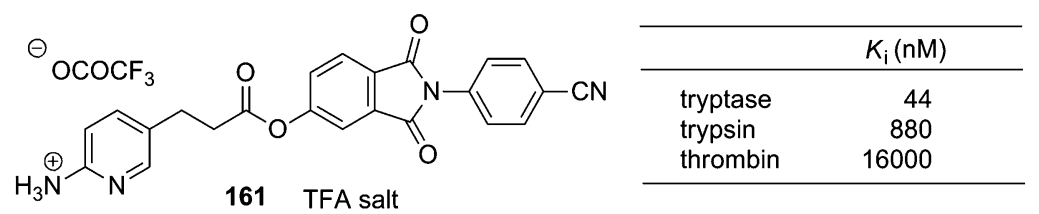

Fig. 27. A Tryptase Inhibitor Derived from Thalidomide

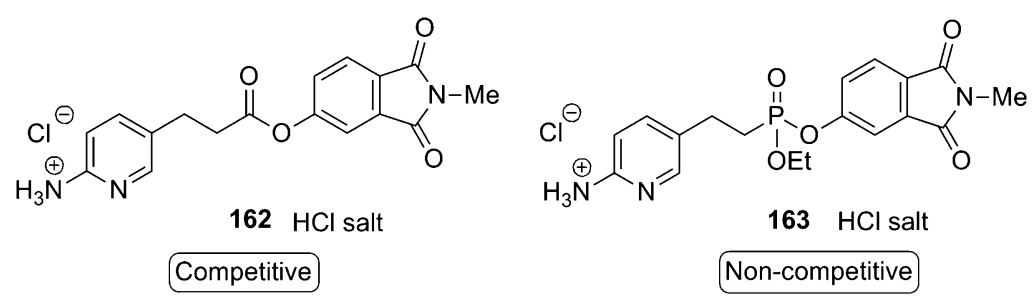

Fig. 28. Alternation of Inhibition Mode by Skeletal Conversion of Carboxylates to Phosphonates

た。構造展開では，フタル酸イミド誘導体 161 のア リールカーボエステル構造が比較的不安定であるこ とから, 加水分解に安定なアリールホスホン酸エス テル構造に置換し安定性を増すこととした. ${ }^{12)}$ フタ ル酸イミド誘導体 161 は, トリプターゼの基質結合 部位における競合阻害を示すことから，テトラヘド ラルなアリールホスホン酸エステル構造で置換した 誘導体は，アリールカーボエステルの水和遷移状態 アナログとして機能して, トリプターゼとの親和性 が高まると期待した. ${ }^{76)}$ 筆者らは，このような誘導 体として，2-アミノピリジンと $N$-メチルフタル酸 イミドをアルキルホスホン酸エステル型のリンカー で連結した誘導体 163 をデザイン・合成した。 ${ }^{165)}$ そして，トリプシン様セリンプロテアーゼに対する 阻害活性について，アリールカーボエステル誘導体 162 の阻害活性と比較した (Fig. 28 and Table 11).

以上の検討から，アリールカーボエステル誘導体 162 は，予想通り，トリプターゼ，トリプシン及び トロンビンに対して阻害活性を示した。しかし，ア リールホスホン酸エステル誘導体 163 は, 当初の標 的であったトリプターゼやトリプシンに対しては高 い阻害活性は認められなかったが，トロンビンに対 して高い阻害活性 $\left(\mathrm{IC}_{50}=1.2 \mu \mathrm{M}\right)$ を示した。 また, Lineweaver-Burk plots の解析から，アリールカー ボエステル誘導体 162 はトロンビンを競合阻害した が，アリールホスホン酸エステル誘導体 163 は，卜 ロンビンを非競合阻害することが明らかとなった。 すなわち，アリールカーボエステル構造をアリール
Table 11. $\mathrm{IC}_{50}$ Values of Carboxylate $\mathbf{1 6 2}$ and Phosphonate 163

\begin{tabular}{lcc}
\hline \hline & $\mathrm{IC}_{50}(\mu \mathrm{M})$ for $\mathbf{1 6 2}$ & $\mathrm{IC}_{50}(\mu \mathrm{M})$ for $\mathbf{1 6 3}$ \\
\hline tryptase & 0.20 & $>10$ \\
trypsin & 2.9 & $>10$ \\
thrombin & 7.0 & 1.2 \\
\hline
\end{tabular}

ホスホン酸エステル構造に置換するだけで，酵素選 択性が劇的に変化するばかりか，阻害形式が競合阻 害から非競合阻害に変化することを見い出した。

ホスホン酸誘導体を基盤とする酵素阻害剤の創製 研究において，基質構造にホスホニル基を組み込む と，阻害形式が競合阻害から非競合阻害に変る現象 が観察されることがあった．以上の発見は，その典 型的な現象の 1 つと考えられる. 現在, アリールホ スホン酸エステル誘導体 163 をリードとして構造最 適化が行われている。これらの研究で，以上の現象 が分子レベルで解明されれば，類似構造を有する化 合物群への適用も考えられ，新しい創薬手法の開発 につながると思われる，今後の展開が楽しみである.

\section{9.おわりに}

本研究は，長年にわたる研究生活のうち，1990 年以降に行われもののなかで，特にリン原子団を有 する化合物の合成と生物活性に焦点を絞り総説にま とめた．研究テーマによっては，十分な展開ができ ておらず，見苦しいものもあると思いつつ論文をま とめた．しかし，いくつかの研究テーマでは，共同 研究者に恵まれて, 細胞内の情報伝達機構の生化学 
的解明や酵素阻害メカニズムの生物物理学的な解明 に分子プローブとして利用できる生物活性ホスホン 酸誘導体を見い出すことができた．本研究テーマ立 ち上げ時の目標がある程度達成されたと考えてい る。また，定年間近ではあったが，ホスホン酸誘導 体の生物活性に関する新たな側面を発見することが でき，今後の展開を楽しみにしている.

謝辞本研究は, 東京薬科大学薬学部薬品製造 工学教室, 分子機能解析学教室において, 教室員と 大学院生・学生とともに行ってきたものであり, 研 究推進に御尽力を頂いた皆様に心より感謝を申し上 げます，特に，学生時代から研究の厳しさと方向性 について御指導頂いた加納慎蔵東京薬科大学名誉教 授 (故人), 渋谷 皓東京薬科大学名誉教授に深謝 いたします。共同研究に快く応じて頂き，種々の御 助言と御指導を頂いた占野廣司福岡大学名誉教授, 福岡大学生化学教室添田秦司教授に深甚なる感謝の 意を表します。また，X 線結晶構造解析や精密な 阻害定数の測定などで御協力頂いたワルシャワ大学 Bzowska 教授に感謝します。研究テーマの立ち上 げ時に, 大学院生として，その後教員として研究に 御協力頂いた山岸丈洋奥羽大学薬学部教授に感謝し ます。本研究の一部は，日本学術振興会外国人招へ い事業（外国人招へい研究者長期・短期）により来 日した研究者（Kaboudin 教授）の協力により実現 できました。招へいを支援して頂いた日本学術振興 会に感謝いたします。最後に，本研究に御支援を 賜つた本学はもとより，日本学術振興会科研費補助 金及び文部科学省私立大学ハイテクリサーチ事業か らの研究助成に対して深謝いたします。

利益相反＼cjkstart開示すべき利益相反はない.

\section{REFERENCES}

1) Overman L. E., Yokomatsu T., J. Org. Chem., 45, 5229-5230 (1980)

2) Yokomatsu T., Shibuya S., Yuki Gosei Kagaku Kyokai Shi, 46, 626-637 (1988).

3) Yokomatsu T., Yuasa Y., Shibuya S., Heterocycles, 33, 1051-1078 (1992).

4) Shibuya S., Yokomatsu T., Yuasa Y., "Studies in Natural Products Chemistry," Vol. 12, ed. by Rahman A. U., Elsevier, Amsterdam,
1993, pp. 445-498.

5) Shibuya S., Yakugaku Zasshi, 124, 725-749 (2004).

6) Engel R., Chem. Rev., 77, 349-367 (1977).

7) Hilderbrand R. L., "The Role of Phosphonates in Living Systems," CRC Press, Boca Raton, 1983.

8) Blackburn G. M., Chem. Ind., 134-138 (1981) .

9) Blackburn G. M., Kent D. E., J. Chem. Soc., Perkin Trans. 1, 913-917 (1986).

10) Lalinde N., Tropp B. E., Engel R., Tetrahedron, 39, 2369-2372 (1983).

11) Bartlett P. A., Hanson J, E., Giannousis P. P., J. Org. Chem., 55, 6268-6274 (1990).

12) Engel R., "Synthesis of Carbon-Phosphorus Bonds," CRC Press, Boca Raton, 1988.

13) Engel R., Org. React., 36, 175-248 (1988).

14) Pudovik A. N., Konovalova I. V., Synthesis, 81-96 (1979).

15) Yokomatsu T., Yamagishi T., Shibuya S., Yuki Gosei Kagaku Kyokai Shi, 53, 881-892 (1995) .

16) Yokomatsu T., Shibuya S., Tetrahedron: Asymmetry, 3, 377-378 (1992).

17) Burke T. R., Smyth M. S., Otaka A., Nomizu M., Roller P. P., Wolf G., Case R., Shoelson S. E., Biochemistry, 33, 6490-6494 (1994).

18) Yokomatsu T., Yamagishi T., Matsumoto K., Shibuya S., Tetrahedron, 52, 11725-11738 (1996)

19) Wynberg H., Smaardijik A. A., Tetrahedron Lett., 24, 5899-5900 (1983).

20) Smaardijik A. A., Noorda S., van Bolhuis F., Wynberg H., Tetrahedron Lett., 26, 493-496 (1985)

21) Yamagishi T., Ph.D. Thesis, Tokyo University of Pharmacy and Life Sciences, March 1997.

22) Finn M. G., Sharpless K. B., "Asymmetric Synthesis, Vol. 5, Chiral catalysis," ed. by Morrison J. M., Academic Press Inc., San Diego, 1985, pp. 247-308.

23) Hayashi M., Matsuda T., Oguni N., J. Chem. Soc., Chem. Commun., 1364-1365 (1990).

24) Katsuki T., Sharpless K. B., J. Am. Chem. Soc., 102, 5974-5976 (1980).

25) Sasai H., Suzuki T., Arai S., Arai T., Shibasaki M., J. Am. Chem. Soc., 114, 44184420 (1992). 
26) Sasai H., Suzuki T., Itoh N., Shibasaki M., Tetrahedron Lett., 34, 851-854 (1993).

27) Yokomatsu T., Yamagishi T., Shibuya S., Tetrahedron; Asymmetry, 4, 1779-1782 (1993).

28) Yokomatsu T., Yamagishi T., Shibuya S., J. Chem. Soc., Perkin Trans. 1, 1527-1534 (1997).

29) Yokomatsu T., Yamagishi T., Shibuya S., Tetrahedron: Asymmetry, 4, 1783-1784 (1993).

30) Rath N. P., Spilling C. D., Tetrahedron Lett., 35, 227-230 (1994).

31) Arai T., Bougauchi M., Sasai H., Shibasaki M., J. Org. Chem., 61, 2926-2927 (1996).

32) Sasai H., Arai S., Tahara Y., Shibasaki M., J. Org. Chem., 60, 6656-6657 (1995).

33) Hirashima S., Arai R., Nakashima K., Kawai N., Kondo J., Koseki Y., Miura T., Adv. Synth. Catal., 357, 3863-3867 (2015).

34) Patel D. V., Rielly-Gauvin K., Ryono D. E., Tetrahedron Lett., 31, 5587-5590 (1990).

35) Patel D. V., Rielly-Gauvin K., Ryono D. E., Tetrahedron Lett., 31, 5591-5594 (1990).

36) Patel D. V., Rielly-Gauvin K., Ryono D. E., Free C. A., Rogers W. L., Smith S. A., DeForrest J. M., Oehl R. S., Petrillo E. W. Jr., J. Med. Chem., 38, 4557-4569 (1995) .

37) Peyman A., Budt K.-H., Spanig J., Stowasser B., Ruppert D., Tetrahedron Lett., 33, 45494552 (1992).

38) Stowasser B., Budt K.-H., Jian-Qi L., Peyman A., Ruppert D., Tetrahedron Lett., 33, 66256628 (1992).

39) Yokomatsu T., Yamagishi T., Shibuya S., Tetrahedron: Asymmetry, 4, 1401-1404 (1993).

40) Yokomatsu T., Yoshida Y., Shibuya S., J. Org. Chem., 59, 7930-7933 (1994).

41) Yamagishi T., Kusano T., Kaboudin B., Yokomatsu T., Sakuma C., Shibuya S., Tetrahedron, 59, 767-772 (2003).

42) Yamagishi T., Suemune K., Yokomatsu T., Shibuya S., Tetrahedron Lett., 42, 5033-5036 (2001).

43) Yamagishi T., Suemune K., Yokomatsu T., Shibuya S., Tetrahedron, 58, 2577-2583 (2002).

44) Kaboudin B., Haruki T., Yamagishi T.,
Yokomatsu T., Synthesis, 3226-3232 (2007).

45) Kaboudin B., Haruki T., Yamagishi T., Yokomatsu T., Tetrahedron, 63, 8199-8205 (2007).

46) Suemune K., Ph.D. Thesis, Tokyo University of Pharmacy and Life Sciences, March 2003.

47) Kolb H. C., VanNieuwenhze M. S., Sharpless K. B., Chem. Rev., 94, 2483-2547 (1994).

48) Yokomatsu T., Yoshida Y., Suemune K., Yamagishi T., Shibuya S., Tetrahedron: Asymmetry, 6, 365-368 (1995).

49) Yokomatsu T., Yamagishi T., Suemune K., Yoshida Y., Shibuya S., Tetrahedron, 54, 767-780 (1998).

50) Yokomatsu T., Yamagishi T., Sada T., Suemune K., Shibuya S., Tetrahedron, 54, 781790 (1998).

51) Yokomatsu T., Suemune K., Yamagishi T., Shibuya S., Synlett, 847-849 (1995).

52) Schoepp D. D., Johnson B. G., J. Neurochem., 53, 273-278 (1989).

53) Hutchison A. J., Williams M., Angst C., de Jesus R., Blanchard L., Jackson R. H., Wilusz E. J., Murphy D. E., Bernard P. S., Schneider J., Campbell T., Guida W., Sills M. A., J. Med. Chem., 32, 2171-2178 (1989).

54) Berkowitz D. B., Shen Q., Maeng J.-H., Tetrahedron Lett., 35, 6445-6448 (1994).

55) Otaka A., Miyoshi K., Burke T. R., Roller P. P., Kubota H., Tamamura H., Fujii N., Tetrahedron Lett., 36, 927-930 (1995).

56) Xie Z.-F., Tetrahedron: Asymmetry, 2, 733750 (1991).

57) Faber K., Riva S., Synthesis, 895-910 (1992).

58) Theil F., Chem. Rev., 95, 2203-2227 (1995).

59) Schoffers E., Golebiowski A., Johnson C. R., Tetrahedron, 52, 3769-3826 (1996).

60) Yokomatsu T., Sato M., Shibuya S., Tetrahedron: Asymmetry, 7, 2743-2754 (1996).

61) Weissfloch A. N. E., Kazlauskas R. J., J. Org. Chem., 60, 6959-6969 (1995).

62) Yokomatsu T., Nakabayashi N., Matsumoto K., Shibuya S., Tetrahedron: Asymmetry, 6, 3055-3062 (1995).

63) Uhlmann E., Peyman A., Chem. Rev., 90, 543-584 (1990).

64) Morr M., Ernst L., Schomburg D., Liebigs Ann. Chem., 615-631 (1991).

65) Pragnacharyulu P. V. P., Abushanab E., 
Tetrahedron Lett., 36, 5507-5510 (1995) .

66) Yokomatsu T., Shimizu T., Yuasa Y., Shibuya S., Synlett, 1280-1282 (1995).

67) Yokomatsu T., Sada T., Shimizu T., Shibuya S., Tetrahedron Lett., 39, 6299-6302 (1998).

68) Yokomatsu T., Shimizu T., Sada T., Shibuya S., Hetreocycles, 50, 21-25 (1999).

69) Murano T., Muroyama S., Yokomatsu T., Shibuya S., Synlett, 1657-1660 (2002).

70) Murano T., Yuasa Y., Muroyama S., Yokomatsu T., Shibuya S., Tetrahedron, 59, 9059-9073 (2003).

71) Ralevic V., Burnstock G., Pharmacol. Rev., 50, 413-492 (1998).

72) Hollopeter G., Jantzen H.-M., Vincent D., Li G., England L., Ramakrishnan V., Yang R.B., Nurden P., Nurden A., Julius D., Conley P. B., Nature, 409, 202-207 (2001).

73) Jacobson K. A., Jarvis M. F., Williams M., $J$. Med. Chem., 45, 4057-4093 (2002).

74) Murano T., Kobayakawa H., Yuasa Y., Yokomatsu T., Shibuya S., Synthesis, 187-192 (2005).

75) Murano T., Yuasa Y., Kobayakawa H., Yokomatsu T., Shibuya S., Tetrahedron, 59, 10223-10230 (2003).

76) Collinsová M., Jirácek J., Curr. Med. Chem., 7, 629-647 (2000).

77) Allen M. C., Fuhrer W., Tuck B., Wade R., Wood J. M., J. Med. Chem., 32, 1652-1661 (1989).

78) Manzenrieder F., Frank A. O., Huber T., Dorner-Ciossek C., Kessler H., Bioorg. Med. Chem., 15, 4136-4143 (2007).

79) Yiotakis A., Georgiadis D., Matziari M., Makaritis A., Dive V., Curr. Org. Chem., 8, 1135-1158 (2004).

80) Matziari M., Beau F., Cuniasse P., Dive V., Yiotakis A., J. Med. Chem., 47, 325-336 (2004).

81) Yamagishi T., Yakugaku Zasshi, 134, 915-924 (2014) .

82) Yamagishi T., Haruki T., Yokomatsu T., Tetrahedron, 62, 9210-9217 (2006) .

83) Yamagishi T., Ichikawa H., Haruki T., Yokomatsu T., Org. Lett., 10, 4347-4350 (2008).

84) Yamagishi T., Mori J., Haruki T., Yokomatsu T., Tetrahedron: Asymmetry, 22, 1358-1363
(2011)

85) Haruki T., Yamagishi T., Yokomatsu T., Tetrahedron: Asymmetry, 18, 2886-2893 (2007).

86) Haruki T., Ph.D. Thesis, Tokyo University of Pharmacy and Life Sciences, March 2011.

87) Georgiadis D., Cuniasse P., Cotton J., Yiotakis A., Dive V., Biochemistry, 43, 80488054 (2004).

88) Demang L., Dugave C., Tetrahedron Lett., 42, 6295-6297 (2001).

89) Yamagishi T., Tashiro N., Yokomatsu T., $J$. Org. Chem., 76, 5472-5476 (2011).

90) Gautier A., Heterocycles, 67, 823-837 (2006).

91) Taylor S. D., Kotoris C. C., Hum G., Tetrahedron, 55, 12431-12477 (1999).

92) Yokomatsu T., Shibuya S., Yuki Gosei Kagaku Kyokai Shi, 60, 740-751 (2002).

93) Romanenko V. D., Kukhar V. P., Chem. Rev., 106, 3868-3935 (2006).

94) Smyth M. S., Ford H. Jr., Burke T. R., Tetrahedron Lett., 33, 4137-4140 (1992).

95) Smyth M. S., Burke T. R., Tetrahedron Lett., 35, 551-554 (1994).

96) Solas D., Hale R. L., Patel D. V., J. Org. Chem., 61, 1537-1539 (1996).

97) Obayashi M., Kondo K., Tetrahedron Lett. 23, 2327-2328 (1982).

98) Berkowitz D. B., Eggen M., Shen Q., Sloss D. G., J. Org. Chem., 58, 6174-6176 (1993).

99) Berkowitz D. B., Sloss D. G., J. Org. Chem., 60, 7047-7050 (1995).

100) Berkowitz D. B., Bhuniya D., Peris C., Tetrahedron Lett., 40, 1869-1872 (1999).

101) Halazy S., Gross-Bergès V., J. Chem. Soc., Chem. Commun., 743-745 (1992).

102) Burton D. J., Yang Z.-Y., Tetrahedron, 48, 189-275 (1992).

103) Yokomatsu T., Suemune K., Murano T., Shibuya S., J. Org. Chem., 61, 7207-7211 (1996).

104) Yokomatsu T., Murano T., Suemune K., Shibuya S., Tetrahedron, 53, 815-822 (1997).

105) Yokomatsu T., Ichimura A., Kato J., Shibuya S., Synlett, 0287-0289 (2001).

106) Yokomatsu T., Kato J., Sakuma C., Shibuya S., Synlett, 1407-1410 (2003).

107) Yokomatsu T., Katayama S., Shibuya S., Chem. Commun., 1878-1879 (2001). 
108) Yokomatsu T., Hayakawa Y., Suemune K., Kihara T., Soeda S., Shimeno H., Shibuya S., Bioorg. Med. Chem. Lett., 9, 2833-2836 (1999).

109) Yokomatsu T., Hayakawa Y., Kihara T., Koyanagi S., Soeda S., Shimeno H., Shibuya S., Bioorg. Med. Chem., 8, 2571-2579 (2000).

110) Yokomatsu T., Sato M., Abe H., Suemeune K., Matsumoto K., Kihara T., Soeda S., Shimeno H., Shibuya S., Tetrahedron, 53, 11297-11306 (1997).

111) Yokomatsu T., Abe H., Sato M., Suemune K., Kihara T., Soeda S., Shimeno H., Shibuya S., Bioorg. Med. Chem., 6, 2495-2505 (1998).

112) Yokomatsu T., Abe H., Yamagishi T., Suemune K., Shibuya S., J. Org. Chem., 64, 8413-8418 (1999).

113) Yokomatsu T., Suemune K., Murano T., Shibuya S., Heterocycles, 56, 273-282 (2002).

114) Yokomatsu T., Minowa T., Murano T., Shibuya S., Tetrahedron, 54, 9341-9356 (1998).

115) Otaka A., Mitsuyama E., Kinoshita T., Tamamura H., Fujii N., J. Org. Chem., 65, 4888-4899 (2000).

116) Yokomatsu T., Takechi H., Murano T., Shibuya S., J. Org. Chem., 65, 5858-5861 (2000).

117) Murano T., Takechi H., Yuasa Y., Yokomatsu T., Umesue I., Soeda S., Shimeno H., Shibuya S., Arkivoc, part (viii) , 256-266 (2003) .

118) Hinterding K., Aloso-Díaz D., Waldmann H., Angew. Chem., Int. Ed., 37, 688-749 (1998).

119) van der Geer P., Hunter T., Lindberg R. A., Annu. Rev. Cell. Biol., 10, 251-337 (1994).

120) Burke T. R., Kole H. K., Roller P. P., Biochem. Biophys. Res. Commun., 204, 129134 (1994).

121) Chen L., Wu L., Otaka A., Smyth M. S., Roller P. P., Burke T. R., Denhertog J., Zhang Z. Y., Biochem. Biophys. Res. Commun., 216, 976-984 (1995).

122) Kole H. K., Smyth M. S., Russ P. L., Burke T. R., Biochem. J., 311, 1025-1031 (1995).

123) Burke T. R., Ye B., Yan X., Wang S., Jia Z., Chen L., Zhang Z.-Y., Barford D., Biochemistry, 35, 15989-15996 (1996).

124) Ye B., Burke T. R., Tetrahedron, 52, 9963-
9970 (1996).

125) Yokomatsu T., Murano T., Umesue I., Soeda S., Shimeno H., Shibuya S., Bioorg. Med. Chem. Lett., 9, 529-532 (1999).

126) Murano T., Ph.D. Thesis, Tokyo University of Pharmacy and Life Sciences, March 2004.

127) Bahta M., Lountos G. T., Dyas B., Kim S.-E., Ulrich R. G., Waugh D. S., Burke T. R., J. Med. Chem., 54, 2933-2943 (2011).

128) Soeda S., Shimada T., Koyanagi S., Yokomatsu T., Murano T., Shibuya S., Shimeno H., FEBS Lett., 524, 54-58 (2002).

129) Kolter T., Sandhoff K., Angew. Chem. Int. Ed., 38, 1532-1568 (1999).

130) Nara F., Tanaka M., Hosoya H., SuzukiKoyanagi K., Ogita T., J. Antibiot., 52, 525530 (1999).

131) Nara F., Tanaka M., Masuda-Inoue S., Yamasato Y., Doi-Yoshioka H., SuzukiKonagai K., Kumakura S., Ogita T., J. Antibiot., 52, 531-535 (1999).

132) Murakami M., Iwama S., Fujii S., Ikeda K., Katsumura S., Bioorg. Med. Chem. Lett., 7, 1725-1728 (1997).

133) Hakogi T., Taichi M., Katsumura S., Org. Lett., 5, 2801-2804 (2003).

134) Hakogi T., Yamamoto T., Fujii S., Ikeda K., Katsumura S., Tetrahedron Lett., 47, 26272630 (2006).

135) Yokomatsu T., Takechi H., Akiyama T., Shibuya S., Kominato T., Soeda S., Shimeno H., Bioorg. Med. Chem. Lett., 11, 1277-1280 (2001).

136) Yokomatsu T., Murano T., Akiyama T., Koizumi J., Shibuya S., Tsuji Y., Soeda S., Shimeno H., Bioorg. Med. Chem. Lett., 13, 229-236 (2003).

137) Yamagishi T., Muronoi S., Hikishima S., Shimeno H., Soeda S., Yokomatsu T., J. Org. Chem., 74, 6350-6353 (2009).

138) Koyanagi S., Kuga M., Soeda S., Hosoda Y., Yokomatsu T., Takechi H., Akiyama T., Shibuya S., Shimeno H., Int. J. Cancer, 105, 1-6 (2003).

139) Soeda S., Tsuji Y., Ochiai T., Mishima K., Iwasaki K., Fujiwara M., Yokomatsu T., Murano T., Shibuya S., Shimeno H., Neurochem. Int., 45, 619-626 (2004).

140) Sakata A., Ochiai T., Shimeno H., Hikishima 
S., Yokomatsu T., Shibuya S., Toda A., Eyanagi R., Soeda S., Immunology, 122, 5464 (2007).

141) Sakata A., Yasuda K., Ochiai T., Shimeno H., Hikishima S., Yokomatsu T., Shibuya S., Soeda S., Cell. Immunol., 245, 24-31 (2007).

142) Soeda S., Sakata A., Ochiai T., Yasuda K., Kuramoto Y., Shimeno H., Toda A., Eyanagi R., Hikishima S., Yokomatsu T., Shibuya S., Curr. Drug Therapy, 3, 218-225 (2008).

143) Bzowska A., Kulikowska E., Shugar D., Pharmacol. Ther., 88, 349-425 (2000).

144) Stoeckler J. D., Ealick S. E., Bugg C. E., Parks R. E. Jr., Fed. Proc., 45, 2773-2778 (1986) .

145) Montgomery J. A., Niwas S., Rose J. D., Secrist J. A. III, Babu Y. S., Bugg C. E., Erion M. D., Guida W. C., Ealick S. E., J. Med. Chem., 36, 55-69 (1993).

146) Miles R. W., Tyler P. C., Evans G. B., Furneaux R. H., Parekin D. W., Schramm V. L., Biochemistry, 38, 13147-13154 (1999).

147) Evans G. B., Furneaux R. H., Greatrex B., Murkin A. S., Schramm V. L., Tyler P. C., $J$. Med. Chem., 51, 948-956 (2008).

148) Halazy S., Ehrhard A., Danzin C., J. Am. Chem. Soc., 113, 315-317 (1991).

149) Halazy S., Ehrhard A., Eggenspiller A., Berges-Gross V., Danzin C., Tetrahedron, 52, 177-184 (1996).

150) Tanaka D., Yakugaku Zasshi, 130, 315-323 (2010) .

151) Hikishima S., Isobe M., Koyanagi S., Soeda S., Shimeno H., Shibuya S., Yokomatsu T., Bioorg. Med. Chem., 14, 1660-1670 (2006).

152) Hikishima S., Hashimoto M., Magnowska L., Bzowska A., Yokomatsu T., Bioorg. Med. Chem. Lett., 17, 4173-4177 (2007).

153) Hikishima S., Hashimoto M., Magnowska L., Bzowska A., Yokomatsu T., Bioorg. Med. Chem., 18, 2275-2284 (2010).

154） Yatsu T., Hashimoto M., Hikishima S., Magnowska L., Bzowska A., Yokomatsu T., Nucleic Acids Symp. Ser., 52, 661-662 (2008) .

155) Iwanow M., Magnowska L., Yokomatsu T.,
Shibuya S., Bzowska A., Nucleos. Nucleot. Nucleic Acids, 22, 1567-1570 (2003) .

156) Luić M., Koellner G., Yokomatsu T., Shibuya S., Bzowska A., Acta Crystallogr. Sect. D, 60, 1417-1424 (2004).

157) Glavaš-Obrovac L., Suver M., Hikishima S., Yokomatsu T., Bzowska A., Nucleos. Nucleot. Nucleic Acids, 26, 989-993 (2007) .

158) Breer K., Wielgus-Kutrowska B., Hashimoto M., Hikishima S., Yokomatsu T., Szczepanowski R., Bochtler M., Girstun A., Staroń K., Bzowska A., Nucleic Acids Symp. Ser., 52, 663-664 (2008).

159) Chojnowski G., Breer K., Narczyk M., Wielgus-Kutrowska B., Czapinska H., Hashimoto M., Hikishima S., Yokomatsu T., Bochtler M., Girstun A., Staroń K., Bzowska A., Biochem. Biophys. Res. Commun., 391, 703708 (2010).

160) Breer K., Glavas-Obrovac L., Suver M., Hikishima S., Hashimoto M., Yokomatsu T., Wielgus-Kutrowska B., Magnowska L., Bzowska A., FEBS J., 277, 1747-1760 (2010) .

161) Breer K., Wielgus-Kutrowska B., Girstun A., Staroń K., Hashimoto M., Hikishima S., Yokomatsu T., Bzowska A., Biochem. Biophys. Res. Commum., 391, 1203-1209 (2010).

162) Glavaš-Obrovac L., Suver M., Hikishima S., Hashimoto M., Yokomatsu T., Magnowska L., Bzowska A., Chem. Biol. Drug Des., 75, 392-399 (2010) .

163) Wielgus-Kutrowska B., Breer K., Hashimoto M., Hikishima S., Yokomatsu T., Narczyk M., Dyzma A., Girstun A., Staroń K., Bzowska A., Bioorg. Med. Chem., 20, 6758-6769 (2012).

164) Tetsuhashi T., Ishikawa M., Hashimoto M., Hashimoto Y., Aoyama H., Bioorg. Med. Chem., 18, 5323-5338 (2010).

165) Aoyama H., Ijuin R., Kato J., Urushiyama S., Tetsuhashi M., Hashimoto Y., Yokomatsu T., Bioorg. Med. Chem. Lett., 25, 3676-3680 (2015). 